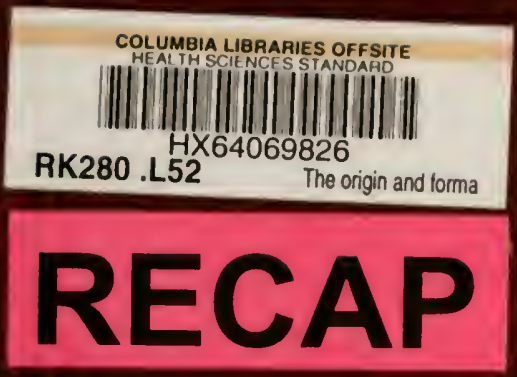




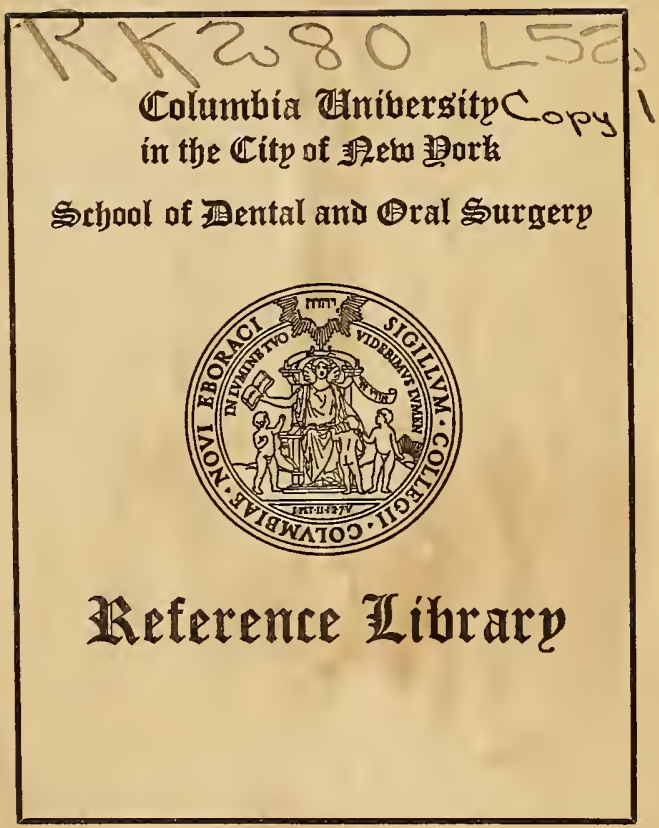


Digitized by the Internet Archive in 2010 with funding from Columbia University Libraries 




\section{THE ORIGIN ANE RORMATION}

\section{OF T1IK \\ DENTAL FOLLICLE.}

THE FIRST MEMUIR ON THE

\section{IEV LLOPMENT OF TIE TELTH.}

BY

DRS. CH. LEGROS AND E. MAGITOT.

A TRANSLATION Fron TIE FRExCH, WITH INTRO-

DUCTION AND NOTES,

BY M. S. DEAN.

Atthohlzed and Reviewed re Dr. Magitot. the

SURVIVING AtTHOR.

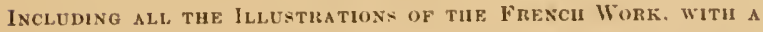
Number of Anditional Illugtiations, Selectfid and Original.

C.HIIAO:

JANSEN, MCCLURG AND COMPANY.

1880. 


\section{$\pi k 280$ \\ 452 \\ Copy 1}

CoPXRIGHT, 1879 ,

Bx M. S. DEAN. 


\section{TRANSLATOR'S PREFACE.}

A apology will reasonably be expected for preA senting this translation to the profession. It will require but lew words, and I checrfully offer it. 'The deficiency and inacentacy of the literature, in ont own langnige. on the origin and derelopment of the "tooth-germ" and its associate parts, render it almost worthless, as compared with the more recent researches of foreign investigators. The only exception I would make is that of the viluable work of Professor 'Tomes. If anything more is required, I refer the realer to the fullowing pages, which, so fatr as I have been able to do justice to the authors, will be their own apology.

Some of you will remember that, nearly twenty year's ago, one of the anthors of this memoir, Dr. Iragitot, in connection with Dr. Cls. Rubin, wrote a treatise entitled, The Genesis and Development of the Dental Follicle, to the Epoch of the Eruption of the Teeth, a large portion of which was translated for the Dental C'osmos.

While the writers of that treatise gave a detailed and elaborate accomnt of the development of the jaws and their anatomical constituents, that portion deroted to the origin and formation of the dental follicle was in many respects incomplete, and in some particulars erroneous. 
The improved methods of preparing sections for microscopic examination which have since been adopted, together with the experience gained by many years of study, which one of these authors has since devoted to this and kindred subjects, has enabled him, with the aid of his eminent colaborer, not only to correct the errors of that work, but also to describe these parts more minutely, and with greater exactness than had been hitherto possible.

While the present work traverses a portion of the ground gone over by the previous writers, it is, nevertheless, a distinct memoir, rendered more comprehensive, and more complete in detail, by the study of the development of the dental system not only in man, but in many other mammifera.

Althongh the work may not be considered as a "practical treatise," in the ordinary acceptation of the term, yet it contains valuable lessons which may be applied in preventing the disastrous consequences of those exanthematoms diseases which are so liable to arrest or pervert the nutritive supply to these developing organs, and which often result in the disfigurement, and sometimes in the entire loss, of the teeth. Hence its suggestions shonld not be confined to the dental surgeon alone, but should be made available by the medical practitioner, who, at the present day, retains almost undispnted possession of this sadly neglected field of practice.

The illustrations, including copies of all those contained in the original, were execnted by Baker 
of Co., of this eity; and, while all of them, I think. complare favorably with the woodents fommd in similar works, - some of them showing the minute detail of the parts during the different stages of development, - are remarkibly faithful to nature.

How well the work of the translator has been done must be left for other's to decide. It may be proper to state. howerer, that it has heen submitted to Dr. Magitot, and meets with his unqualilied approral.*

The conversational style in which many of the notes have bern introdnced. may be regarded by some as unsuited to the character of a sererely scientific work. Howerer this may be, it certainly affords the translator opportunities of presenting. in an easy and familiar manner. the views of different anthors, and some other valuable matter, which he believes conld not otherwise be introduced without ajparent abruptuess. Ife believes. also, that the plan here adopted will reliere the monotonous strin upon the less scientific reater, and that the facts thus brought ont will be more vividly impressed upon most minds thin if presented in the ordinary way. If this be so, no other defense is necossiry.

The adjectival terms thenoting the species of embryos - as eqnine, borine, etc.. and corresponding to that of human - which have been adopted

* Extract from his letter. Paris, Sept. 8, 1879: "Je trouce retle traduction pafaite, et je recounais que' rotre "Trans. lator's Introduction est wis inginieuse pour méparer le lectere à l'intelligence dlu mémoire." 
in the translation, I think, cannot be regarded with disfaror; the propriety, if not the necessity, of their employment in works of this kind seems to me unquestionable.

My labors upon this work have been lightened by the encouraging words of many leading members of the medical, as well as the dental, profession; and to my esteemed friend and eminent fellow-practitioner, Dr. G. II. Cushing, I am indebted for much kind assistance in preparing this treatise for publication. And especially to Dr. Magitot, the illustrious anthor of many scholarly contributions to science, I must offer my grateful acknowledgments for the cheerful aid he has so promptly rendered me in the execution of this work.

M. S. D.

34 Monroe Street, Cincago:

October, 1879. 


\section{CONTENTS.}

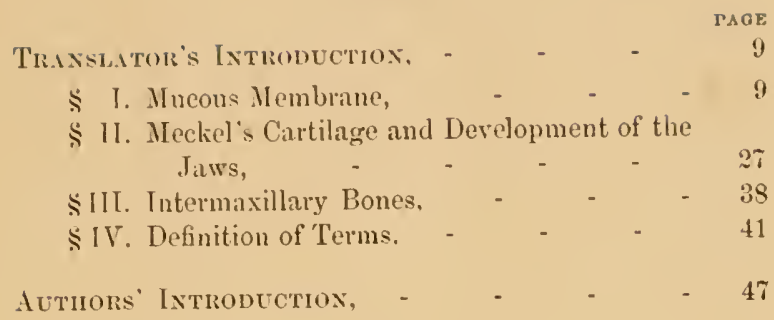

\section{CHAPTER I.}

Condition of the Jaws of the Embryo at the period of the Genesis of the Follicle-The Epithelial Ridge (Bourrelet),

\section{CHAPTER II.}

Epithelial Lamina, and the Genesis of the Enamelorgan,

CHAPTER III.

Origin and Formation of the Dental Bulb and of the Follieular Trall (Sae)

\section{CIIAPTER IV.}

Phenomena that follow the Formation of the Follicle and the Rupture of the Epithelial Cord, - - 115 


\section{CHAPTER V.}

The Place and Mode of Origin of the Follicles of the Permanent Teeth, PAGR

\section{CHAPTER VI.}

Chronology of the Dental Follicle, or the Periods in which its several Component Parts appear,

CHAPTER VII.

Criticism of Theories, Résumé, etc., $\quad$ - $\quad$ - 169

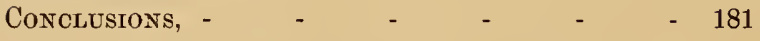

Summary of Illustrations and Brief Descrip-

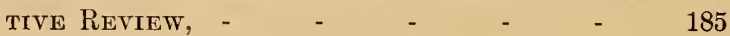




\section{TRANSLATOR'S INTROIUCCTION.}

[Teacher and his Puphls, Casper and Fraxk.]

TEACHER: I propose to consider the Ori1 grin and Formation of the Dental Follicle in Mammals; and for this pmpose I shall read the valuable memoir of Drs. Legros and Magitot, which furnishes the most complete aceomnt of these plienonena of any work within my knowledge. I sliall use this treatise as a text, elaborating as we proceed, whenerer suggestions may ocem to me, or in response to questions from you. In this manner we may hope to arrive at a satisfactory molerstanding of the subject.

\section{§.-MUCOUS MEMBRANE.}

You are presumed by these antliors to be acquainted with the general anatomy and physiologg of the parts fiom which the teetl are 
directly derived. Indeed, withont this knowledge you cannot obtain a very clear idea of the origin and erolution of the tooth-germs, even from the minnte description given in these pages. I think it will be well, therefore, before commencing our readings, to hastily review the parts immediately concerned in the production of the teeth, and especially the epidermis or epithelinm, which constitutes the external layer of the mucous membrane.

CAsper: I ought to have a pretty fair knowledge of these parts; if not, it is no fault of mine, for I lave faitlfully studied Biesiadecki, Kölliker and Klein; and yet I must confess that my knowledge is badly confused, especially in regard to the mucous membrane; for these anthors do not represent this tissue by descriptive figures, as they do the skin. Besides, the names giren to the different strata are a good deal mixed; so that I think a review of the subject will not be a waste of time.

Teacher: The difficulties you have encountered do not surprise me; for I have myself had considerable trouble in determining even the location of the layer which some authors liave described under that name. For example: 
(1) According to some anthors, the epidermis alone constitutes the mucous membrane (Guillot and others).*

(2) According to others, the mucous membrane consists of three membranes, viz., " an epithelium, a proper mucous, and a fibrous coat." "The second coat, the proper mucous membrune, is apparently without texture. The third coat corresponds to the corium of the skin."

This is Prof. Hand's definition of the mucons membrane, and essentially that of Prof. Leidy. Here we have the term nucous membrane used both in a general and a special sense, as a whole and as an integral part; the mucons membrane consisting of three layers, one of which is the proper mucous membrane, and the latter seems, from its description, to be identical with the "basement membrane" of Todd and Bownan.

"Prof. Wedl, in his "Pathologie der Zülme" (Leipzig. 18\%0), under the heading of Dexelopment of the Teeth, designates the mucous membrane as an epilhelial structure, and calls the enamet-organ a folliele of mucons eells: "Dieser Schleimzellenschlaueh wurde von Kö̈lliker als Schmelzkeim bezeichnet." This phraseology, to one who had studied Frey, Magitot, Kö̈lliker, Flint, Klein, and many other physiologists who have deseribed the mucous membrane, would render Wedl's description unintelligible. 
the "intermediate membrane" of Henle, and the "membrana propria" of Kölliker and others.

(3) According to others, again, the layer situated immediately beneath the stratum MLalpighii (and which corresponds with the corium or dermis of the skin) is "the proper mucous membrane" (Kölliker, Klein, Flint, Frey and others). These authors, however, designate the lower portion of the epidermis of the skin by an equivalent term, mucous layer; but occasionally they use the expression mucous membrane in its general sense.

(4) Again, Dunglison and many other authors employ the term mucous membrane in. its broader" sense, as including the "epidermis" and the subjacent layers.*

You see, therefore, that the study of this membrane is rendered unnecessarily difficult by the numerous and often contradictory terms which different writers use in describing it.

*Dunglison says: "In the mucous membrane the same superposition of strata is generally considered to exist as in the skin, viz., epidermis or epithelium, rete mucosum, corpus papillare, and cutis vera."

M. Flourens divides all the mucous membranes into three layers-the derma, epidermis and corpus mucosum. 
Kiilliker and those of lis school divide the mucons membrane (as a whole) into the following layers, counting from the external:

(1) Epithelium: (2) membreno macoser (the proper mucons membrane): (:3) sulmmecosa (submucous membrane), telu mneosu, ete.

Fig. 1.

1st Class. 2d Class. 3d Class. th Class.

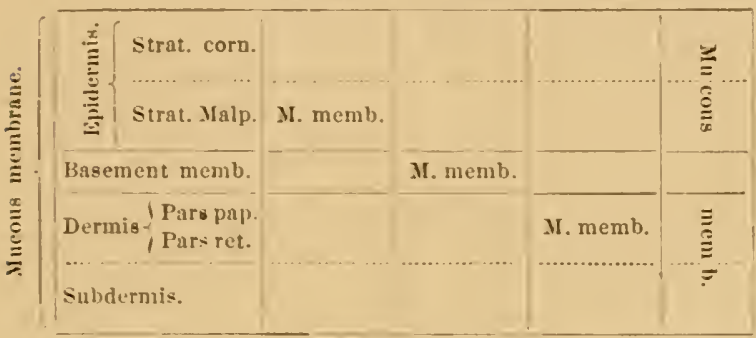

Frc. 1.-The above diagram shows the relative position of the different layers which are designated the mucous, or "proper" mucous membrane by various writers. The column on the left gives the names, and location of the strata of the mucous membrane as we think they should be designated. The horizontal lines show the relative location of these layers, without any regard to their thickness.

Some of these authors call the external portion of the "membram mueosa" the chorion, corim or derma. They also divide the "proper" mucous membrane" into two lavers, the papitlary and the reticulary.

Huxley says the skin and mucons men- 


\section{TRANSLATOR'S INTRODUCTION.}

brane "may be distinguished into three portions; a central plane of indifferent tissue [the basement membrane], from which, growth and metamorphosis take place externally, to constitute the representative of epidermis or epithelium, to which we propose to give the name of ecderon; while internally, growth and metamorphosis take place from the central plane, so as to constitute the representative of the derm or 'mucosa,' which we have termed the enderon."*

Now, since the terms employed by different writers to designate the layers of the skin and of the mucous membrane are so various, and sometimes conflicting, I shall apply the same terms to the corresponding strata in both of them, as follows:

(1) The term epidermis will comprehend the whole of the external epithelial layer, whether it be of the skin or of the mucous membranes. (2) The term dermis will be applied to the stratum immediately subjacent to the epidermis, and which is known by the various terms, cutis vera, corium, mucosa, proper mucous mem-

*Appendix to the Sydenham edition (4th edition) of Kölliker's Histology. 
brane, ete. These two layers will be suludivided,- the epidermis into two strnta - the rorneous and Malpighiren:* the dermis also into two parts, the papillar!y and reticulary.

The tissues next subjacent to the dermis will be known as the subdemis, corresponding to the subentanea, submucosa, tela mucosa, etc.

In thus applying these terns I make no new departure in our nomenclature, but merely employ the old ones more systematically, and, I think, more rationally.

It must be confusing to the student to find the lower layer of the epidermis of the skin, and the layer that lies beneuth the epillermis of

* The Malpighian layer, as defined by most authors, includes those epithelial cells (of the epidermis) that lie subjacent to the horny layer, whether their form be columnar, polygonal or otherwise; but some authorities, among whom are Legros, Magitot, Tomes and Kiliss, limit the term stratum Malpighii to the lowest layer of cells, which stand vertically, like palisades, upon the surfice of the dermis. This single liyyer of columnar, or cylindrical cells, as they are sometimes called, is also termed the prismatic layer by Legros and Iragitot. - a term which is, to my mind. definite and not liable to mislead the student; and hence will be employed in the following translation wherever it occurs in the original. 
the mucons membrane,- parts which are locally, anatomically, and functionally, different,-both designated by the same name; and not to find a dermis beneath the epidermis. The term dermis cannot be objected to, as applied to a layer of the mucous membrane, since the growths originating in this stratum are universally denominated dermal tissnes.

For the reasons here stated, I believe I am justified in adopting the simple system of terminology indicated above.

With this designation of terms, we will proceed with our description of the mncons membrane, and more especially the exterior layerthe epidermis, from which the tooth-germs directly originate.

The mucous membrane and the stin are anatomically analogons and continuous structures. The first clothes the internal, and the other the external, surfaces; and the description of the one will, with slight modifications, apply to the other. In a general sense, they are composed of two strata or layers, the dermis and the epidermis; yet for convenience of description, rather than for any other reason, they have been variously subdivided. 
The external stratmu, the pridermis. conposed entirely of epithelial cells, has been deseribed as consisting of two layers - the external being termed the cormeous and the internal the Malpighien. "The "scart-skin" raised on the extermal surfice of the skin by a blister, and the pellicle detached from the palate by hot drinks, represent the corneous layer of the epidermis: by some authors this is called the "true epidermis," and by some the "cuticle." This layer is composed of the old epithelial cells which have ceased to perform any of the vital functions. 'The subjacent layer', formed of living epithelial cells, which vary in form and size, is denominated (among many otleer terms) the strutum Malpighii.

Underneath these two subdivisions of the epidemis of the mucous membrane (according to the nomenclature liere adopted) we shall find the dermis (derm or derma). .But lest I should mislead you I will mention here that there is a transparent amosphous pellicle which separates the lower stratum of the epidermal cells from this latter layer. This struetureless tissue is described by Todd and Bowman under the name of basement membrane, and by Henle under that 
of intermediate membrane. Now, although the existence of a "membrane" here is disputed by many, yet there can be no doubt that a homogeneons structure is interposed between these layers, and that in some parts it presents the character of a membrane of considerable thickness. This membrane is of peculiar interest to the dental physiologist, since the dentine-bulb and the enamel-organ will be found on the opposite sides of it. In this situation it constitutes the membrana proformativa of Raschkow. This tissue is not nsually reckoned among the layers of the skin and mucous membrane; and its further discussion here, as a preformative membrane, would be but to anticipate what will follow in the body of this work.

Inasmuch as the elements of the epidermal membrane (the epithelium) play the most important part in the development of the teeth, as will be seen, hereafter, a more minute description will be given of them than of those of the subjacent stratum.

These elements are derived from the external germinal layer - the corneous leaf or plate, (Remak), or the epiblast, as it is now more generally called. They are developed at an earlier 
period in embryonal life than are the connective-tissue cells of the middle or intermerliate layer-the mesollast, from which the dermis originates.

As early as the 35th day (as nearly as I am able to ascertain) the epidermis presents two layers of cells; but at this period it cannot be regarded as a membrane composed of two lamine, for the external cells haye not yet attained the requisite age to matmre them into the horny bodies that constitute the corneous layer. The cells constituting the epidermis must, therefore, though differing in form, be regarded, at this stage, as belonging exclusively to the Malpighian stratum (in its broader sense). But soon the transforming hand of time will convert them into the corneous layer; when the oral epidermis will be, like that of the skin, divisible into two lamina.* If we examine these two epi-

*In his last edition (5th), under the head of "Epithelinm of the carity of the mouth," Kölliker remarks that "the elements that constitute this epithelium [epidermis] are not divisible, like the epidermis [of the skin], into two clearly distinet laminie, but constitute one connected layer, more resembling the mucous layer, but representing also the corneous layer."

It may be true that in some portions this epidermis 
dermal strata of the mucous membrane more closely, we shall find them composed of quite regular layers of epithelial cells, which (commencing with the lowest) may be described as the infant cells, the youthful cells, the adult cells, the aged cells, and the dead cells.

The cells composing the stratum corneum belonged in their infancy to the lowest layer of the stratum Malpighii; in FIG. 2. their youth to a more external layer known as the "prickle," "spinous," "ridged," "aculeated," or " imbricated" cells (all of which terms are applied to cells represented in Fig. "Fig. 2.-" "Spidged," or "imbri2). In their middle life they cated " cells. (From belonged to the polygonal Frey.) cells ("pavement, or tessellated epithelium"), which lie still nearer the surface; and in their old age, to the elongated, flattened cells, in which the nuclei have nearly disappeared; and finally,

is not so readily divisible as that of the skin; but it is known with what facility a pellicle may be raised from the palatal portion - the rugæ for example-by drinks that are not sufficiently hot to produce the same effect upon the skin. 
as dead cells, they ocenpy the most ontward, the comeons layer of the epidermis.

The cells of the lowest layer (the infant cells) stand rertically, like palisades, upon the basement membrane (c); which latter separates the epidermal from the dermal stratum of the mucous membrane; or in other words, the basement membrane separates the epithelimm from the "nucosa," "proper" mucous nembrane," or " corium." These cells, which may be likened to the blocks of a Nicholson parement when set in position, constitute what is called varionsly matic.) FIg. 3.

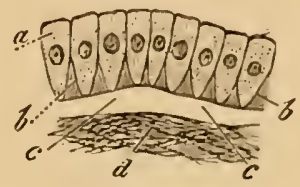

Fici, 3.- a, cylinder, columnar or prismatic cells of the mucous membrane, or "infant cells "; $b$, intermediate matter; $c$, basement membrane; d, fibrous tissue of the dermis. (From F'vey. Diagramthe prismatic, colummar, cylindrical, and, perhaps less properly, the Malpighian layer. They have large oval nuclei, and are said to be destitute of a cell-wall. In the embryo (according to Henle) they appear like a stratum of protoplasm regularly studded with nuclei. This layer of prismatic cells offers additional interest to the dental student, since it constitutes the peripheral portion of the enamel-organ, including that spe- 
cial area which, during the course of development, will be known as the "enamel-membrane" ("internal epithelium of the enamel-organ" of Kölliker, or "membrana adamantina" of Rascllkow), and which here either is converted into enamel or produces it. But more of this anon. The next lajer or layers of cells (the youthful) have grown larger, and, besides their imbricated appearance, are surrounded by a thin cell-wall, periplast (Huxley), or formed material (Beale). The cells external to these assume larger proportions and are more polygonal in form, and represent these cells in their middle life. The cellwall, or periplast, has increased in thickness, while the nucleus has proportionally diminished in size.

FIG. 4.

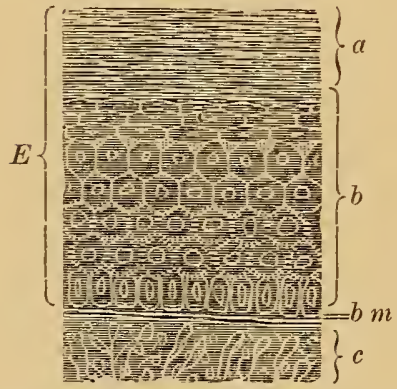

figure, nor is the subdermal layer.
FIg. 4.-This cut was designed to illustrate the cells of the epidermis. $E$, in some of their various phases, as described above. $a$, Stratum corneum; $b$, stratum Malpighii, with its prismatic or columnar layer resting upon the basement membrane $b \mathrm{~m}$; $c$, the upper portion of the dermis. The papillæ are not represented in this 
The cells still exterual to these are the agd cells, and the nearer tiey approach the corneons stratum the larger will be the amount of "formed material" that surrounds the nuclens; till at last only a trace of the latter is risible. or it entirely disappears, and these cells enter the horny larer and become the dead cellsa lifeless protecting corering for the living elements that are growing up beneath.

Thus these cells. during their passage from the intemul to the extemal surituce, have undergone all these changes, until from prismatic or columuar cells they hare tinally become thin. liteless scales, which are continually cast off as foreign or effete matter. During the entire life of a person these cells are continually passing away: and hence the production of new generations of them must be equally incessant. This reproduction takes place from the lower larer of vertical cells, $i$. e. the cells that constitute the prismatic or columnar layer: at least this is now the most generally accepted opinion of physiologists, though with some respectable exceptions.

The external layer (stratum coneum) of the uncous nembrane. mlike that of the skin, is 
permeable by various kinds of liquids; which, after passing through the softer portions of the epidermis and the basement membrane, may be absorbed by the vessels of the dermis (proper mucous membrane, corium).*

Now, lest your patience be too heavily taxed, we will take only a very hasty glance at the subjacent layer of the mucous membrane, ignoring, for the time being, the existence of the basement membrane.

Lying immediately beneath the epidermis we find a fibro-vascular membrane of variable thickness, which we call the dermis (the proper mucous membrane, the mucosa, mucous layer,

* Kölliker (Loc. Cit., 5th ed.) says: "The epithelium of the mouth, though thick, is very pervious, a characteristic which distinguishes it from the epidermis [of the skin], of which the mucous layer [stratum Malpighii] alone possesses this quality. It allows the various kinds of liquids to pass through it from without inward, which, when brought in contact with the mucous membrane [the dermis], may be absorbed by the vessels, or become cognizant to the nerves received by this membrane."

Kölliker does not recognize the existence of nerves in any part of the epidermis. If the experiments of Langerghans and Podcopaëw are reliable, the liquids need only enter the Malpighian layer to be brought in contact with the nerve filaments that penetrate this soft layer. 
cutis vera, coriun, chorion, etc.) This is contimuons with the dernis of the skin, and grradually merges into the subdermal areolar tissne, with which it is strongly and intimately connected. The external portion of the dermis is known as the pars papillaris (papillary part), and the subjacent portion as the jars reticularis (reticulary or netted part). But we cannot dwell mpon these particulars, which do not, in fact, exist in the dermis at the early period of embryonal life when the development of the teeth commences. I will say, howerer, that the prominent constituents of the dermis are the connectivetissne elenents; bnt, as before stated, the cells of the mesobiust, to which this layer belongs, are not developed at so early a period as those of the epiblast, from which the epidermis is derived. For example, till the forty-fith day of gestation, and perhaps later, the dermis is represented by a nucleated mass of enbryonal tissne, in progress of erolution, while at the same stage the epidermul cells are completely developed.

From the external surifice of the dermis rises the dentine-bulb, or clentinul prpilla; thongh nany anthors state that the papilla originates in the "submucons" tissme. This latter tissue or 
membrane corresponds with what I have termed. the subdermal tissue. But to me it is evident that the dentinal papilla first appears as a little. nodule upon the surface of the iayer subjacent to the basement membrane-the dermis.

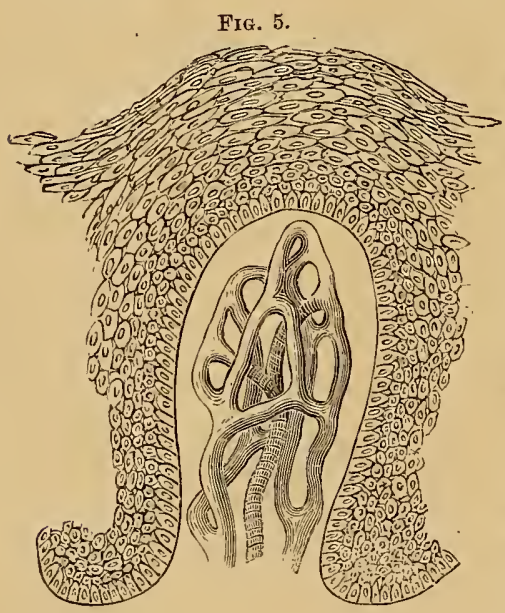

Fig. 5.-This cut is taken from Kölliker's Man'l of Hist. It has been widely copied by histological writers, and represents "a simple papilla [of the mucous membrane]: with manifold vessels and epithelium, from the gums of an infant, magnified 250 diam." It is given here principally to show the epidermal covering, though the cells are represented only approximately correct, the figure being designed mainly to illustrate the vessels of the papilla. It will be observed that the "ridged" cells do not appear in this.

With this imperfect description, which has been confined mostly to the situation of the layers, and to some of the more conspicnous elements of the mucons membrarie, I must drop this fascinating subject; hoping, however, that what has 
been said will repay the time it has occupied, and more especially that the little information you have thus gained will stimulate you to seek a more thorongh knowledge of this very important, and very extensive, branch of histologry and physiology.

SII.-TIEE EARLY DEVELOPMENT OF THE JAWS ; AND MECKEL'S CARTILAGE.

As Meckel's cartilage is allnded to in the first pages of the following treatise, perhaps I had better anticipate your questions in regard to it; for a description, that would be at all satisfactory; wonld make too long a break in the text.

Fraxk: I have seen this cartilage mentioned in various works, bnt never described; and I am curions to learn something of this, to me, mysterions organ.

Tracmen: Since our medical and dental literature is so reticent in regard to this inportant embryonal structure, and the anthors of this work scarcely more than allude to it, I will give you a very brief histerical aeconnt of it. The facts that I shall give yón regarding it have been gathered mainly from a treatise written by Drs. Magitot and Robin (the first named being one 
of the authors of the present work), in which this subject is very fully elaborated, and from which most of the illustrations here given are copied.

I will commence at a period some ten days anterior to the origin of the cartilage, and briefly sketch the progressive development of the jaws till it makes it appearance; and then trace their phenomena together to the time when it disappears.

If we examine a human embryo of fifteen to eighteen days (totál length, little over half an inch), we shall find two tubercles which proceed. from the first visceral arch, and which, when developed, will constitute the lower jaw. These tubercles, processes, tongues, apophyses or bourgeons (take your choice of these terms) gradually approach each other until they unite at the median line, and, at a later period, become ossified.

This union takes place about the twenty-eighth day, at which period the embryo has attained perhaps three-fourths of an inch in length. But coincidently with the growth of these two processes, two other bourgeons, or buds, shoot out from the same "visceral arch" to form the superior maxilla. (Fig. 6, 5, 5). (Fig. 7, g, g).

The growth of these is also toward each 
other: but, mulike the former two, they never mite with each other nor meet at the median line: for there is still a third pair of bomrgeons, called the incisive or intermaxillary, which arise from the forelsead or frontal apophysis; and these, in their downward growth, occupy the central portion of the open space between the maxillary processes. This will be secu by a glance at Fig. 6, 4, and Fig. 7, I, althongrh

FIG. 6 .

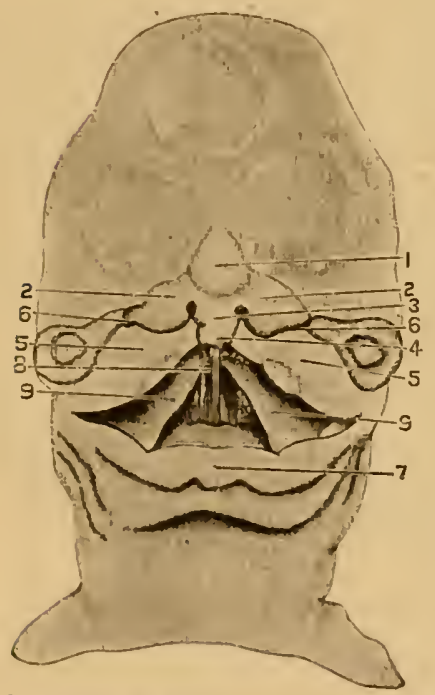

FIG. 6.- Mouth of an embryo of forty days. (Coste.) 1, First appearance of the nose. 2,2 , First appearance of the ala of the nose. $3, \mathrm{Ap}$ pearance of the closure beneath the nose. 4 , vidtlle or mrelian portion of the upper lip formed by the upproacle and union of the two incisire proccsses; the little noteh in the median line still indicating the primitive separation of the two processes. 5,5 , Superior maxillary processes forming the lateral portion of the upper lip. 6, 6, Groove for the development of the lachrymal saes. $\boldsymbol{千}$, Lower lip. 8, Mouth. 9, 9, Lateral lialves of the palatine areh, already nearly approximated in front, but still widely separated behind. 


\section{TRANSLATOR'S INTRODUCTION.}

they have, in these cuts, already united with each other at the median line. These last-named processes, when ossified, will constitute the intermaxillary bones. A line, faintly representing the point of union of these two processes, may be seen in Fig. 7, but is not portrayed in the

Frg. \%.

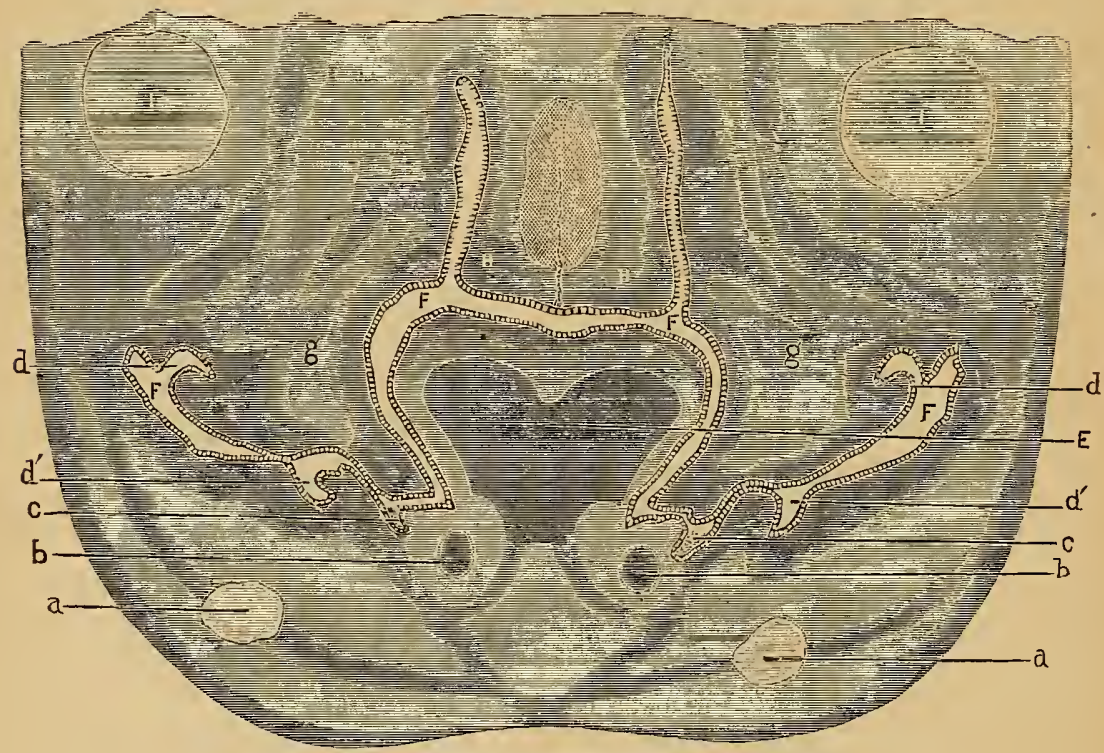

FIG. 7.-A vertical section of the anterior part of the face of a human embryo of forty to forty-five days. Magnified 80 diameters. (Magitot.) $a, \alpha$, Meckel's cartilage; $F, F, F, F$, the mouth; $g, g$, superior maxillæ; $H, H$, incisive, or intermaxillary processes; the perpendicular line showing their point of union with each other. 
original plate. It is added here to aroid griving you the inpression that this is a single prosess. 'There is a slight noteh or cleft still remaining at the lower margin, between the intermaxillary processes (Fig. 6, 4), which in a subject a few days older wonld have been closed.

Soon after the intermaxillary processes lave become mited with each other (say in tive to eight days), their free lateral margins form a juncture, and coalesce with the advancing superior maxillary processes, thus closing the rertical clefts seen in. Fig. 7 (above the letter's F), with the exception of two small apertures for the nostrils. (Fig. 6, 2, 2.) All these processes are outgrowths from the mesoblastic layer, elothed externally with a coat of epithelium from the epiblastic.

From this brief sketch of the mode of development of the maxillary and intermaxillary processes yon. will readily comprehend the origin of that common malformation known as harelip. When from any cause one of the maxillary bourgeons fails to mite with the intermaxillary process, we have "simple hare-lip"; a similar fitilure on botlı sides results in "double hare-lip." If, in addition to these lateral fissures, one oceurs at the median line (which is not frequent), we 
have "complicated hare-lip." Occasionally there is the central fissure alone, in which case the intermaxillary processes have failed to coalesce with each other - a rare occurrence.

We will now return to the lower jaw. As. before stated, the processes (sometimes called the mandibular), from which this maxilla is developed, meet, from abont the twenty-fifth to the twenty-eighth day, and form a union with each other at the median line. (Fig. 6, 7.) Very soon afterward a little cartilaginous band makes itsappearance ("by direct genesis"), and occupies the central portion of the embryonal mass that. now represents the lower jaw. This is

\section{MECKEL'S CARTILAGE}

in its incipient stage of development. It is a small whitish cord, lying in a bed of soft transparent tissue, and may be easily distinguished by the aid of a low magnifying power; and by careful manipulation it may be removed entire from the surrounding mass for examination. This cartilage was first noticed and described (in 1820, I think,) by the celebrated German anatomist whosename it bears. It gives form and stability to the lower jaw of the embryo, serving as a temporary 
skeletom, from an early period till it is no longer needed for that purpose. It is composed of two symmetrical or homologons parts (corresponding to the right and left sides of the jaw), which soon become mited at the mental sympliysis. From this point of juncture they extend, one on either side, to the frane of the tympanum, where they teminate in the mallens. (Fig. S, 7.)

Fig. 8.

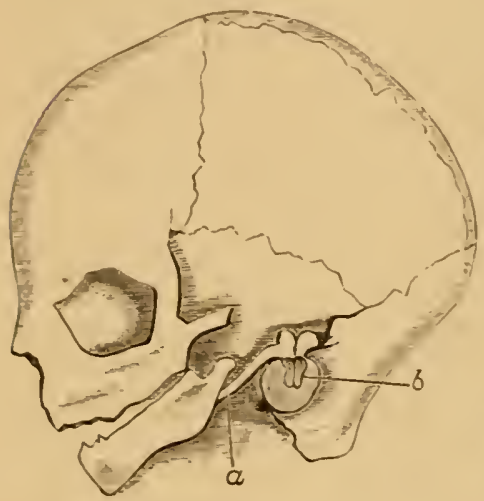

Frg. 8.--Cranium of a liuman feetus of four months, natural size. Dissected for the purpose of showing the membiane of the tympanum at this age, with the eartilages of the incus and of the malleus $(b)$ : also, the extra-tympanic portion of Meckel's cartilage (a). (Magitot (and Robin).

This cartilage is said to constitute the first solid structure that appears in this visceral arch; and from its commencement (about the twentyfifth day), until it entirely disappears," it mndergoes a constant series of modifications.

* Although Meckel, Valentin, and some others, extend the existence of this cartilage to the eighth month in the 
It has scarcely attained its full growth (which period corresponds to the commencement of the ossification of the mallens), $*$ when it begins to waste away and disappear.

Between the thirty-fifth and the fortieth days of embryonal life, slight traces of ossification show themselves at points nearly equidistant between the symphysis and the angle of the future jaw. This extends rapidly, both anteriorly and posteriorly, along the external face of Meckel's cartilage, in immediate contact but not uniting with it; and at about the sixtieth day of gestation a miniature jaw-bone is formed, though not yet perfected. (See figure below.)

Fig. 9. FIG. 9.-Taken from a human embryo of A about sixty days. Natural size. Soft parts removed, showing Meckel's cartilage and the inner, or lingual face of the jaw-bone, left side. The cartilage has much the appearance of a very large hog-bristle. The main object in presenting this figure is to show the stage of development at this early period. $b$, Symphysis; $\alpha$, extratympanic portion of Meckel's cartilage; $n$, manubrium mallei. (Original figure.)

human foetus, yet Drs. Magitot and Robin state that they have never been able to find a trace of it later than the sixth month. As for myself, I have never succeeded in finding the slightest vestige of it, even at the symphysis, at the end of the fifth month.

* The latter part of the third month of embryonal life. 
At this epoch the skeleton of the lower jaw is composed of two arches (if we may include Meckel's cartilage in the term skeleton),-an arch within an arch, in intemal artilaginous and an ertomal osseous one. (Figs. 9 and 11 . represent one of its bi-sections.)

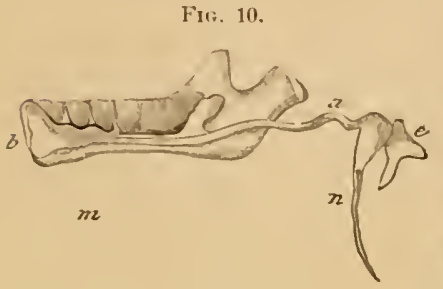

FIti. 111. - Internal face of the right inferior maxilla of a human embryo of about three months, showing the natural size and the relative position of Meckel's cartilage: as also the dental follicles, from which the internal face of the bone is lifted off; a. the extra-tympanic portion, often flexible beyond the orifice of the dental canal; $b$, the symphysis of the cartilage: 11 , the mumlrium mallei (or handle of the hammer), with a little fibrous prolongation; $e$, the cartilage of the incus (or anvil). This figure represents the internal surface of Meckel's eartilage, or the interior of the arch. (Mogilot and Rolin).

In an anatomical view this cartilage consists of two parts - a transitory marillary, or extra-tympunic, and a perwistent auricular part. The former, after it is no longer needed to sus-. tain the jaw, begins to waste away: while the latter, which represents the mallens, gradually hecomes ossified. 
Fig. 11.

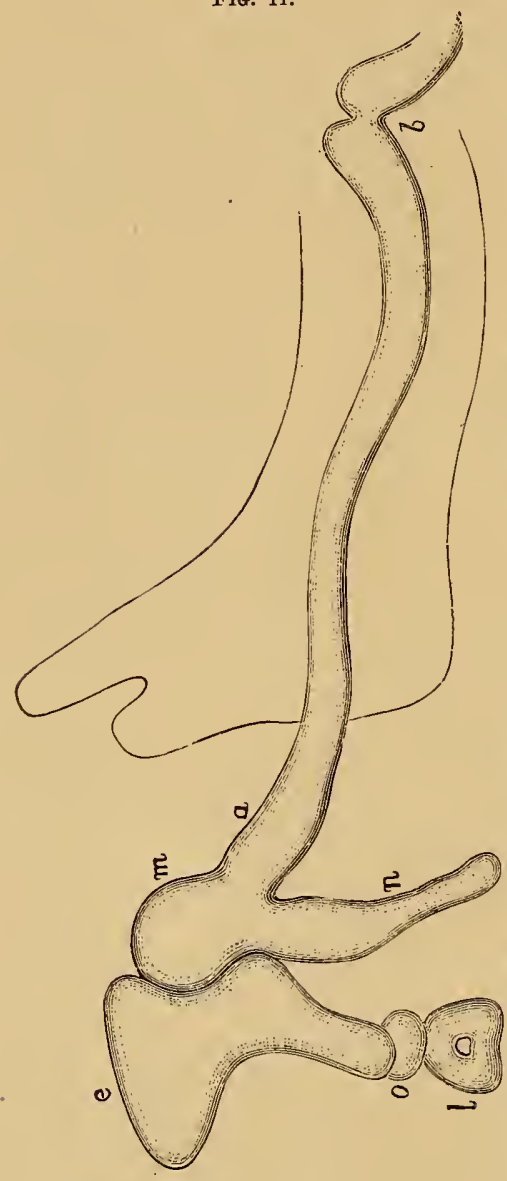

FIG. 11. - Meckel's cartilage, from a human embryo of forty to forty-two days, and before the appearance of the maxillary bone; magnified twentyfive diameters. $a$, Enlargement of the cartilage near its union with the neck of the malleus; $b$, a slightly enlarged portion of the cartilage in the form of a spatula, but contracted at the median line, where it unites with that of the opposite side; $m$, head of the malleus; $n$, handle of the malleus; $e$, cartilage of the incus; $o$, cartilage of the os lenticulare; $l$, cartilage of the stapes. [The outline of a jaw has been added to this figure to show the relative position it will occupy when ossification takes place.] (Magitot and Robin.). 
"This ossitication of the auriculur, and absorption of the trussitory, portions conmence at the end of the third month of intrituterine life: the former with the mallens, the latter at points corresponding with the middle portion of each jaw, whence atroply extends in both directions; and, toward the latter part of the sixth montl, according to these anthors, the cartilage, from the simplyesis to the mallens, entirely disappears, leaving for a time on the surface of the bone a slight groove to mark the place it occupied.

Fraxk: I infer that Meckel's cartilage belongs exclusively to the lower jaw of the human foetus.

Tencher: It is by no means the exclusive lieritage of man. All the different species of manmals, reptiles, fishes, and even birds, in embryoual life possess this transitory, cartilaginous support to the lower jaw. But it does not in all these disappear (as it does in man) before birth. In the rodents, - rats and mice, for example,-it remains withont sensible change till birtl, or a little later.

This brief description, aided by these excellent cuts, will, I hope, give you a sufficiently accurate idea of this cartilage to satisfy you for the present. But if you desire fintlier infor- 
mation, I mnst refer you to the thoronghly exhanstive treatise already alluded to; * for I know of no comparatively complete work upon this subject in the English language.

\section{§ III.-INTER-MAXILLARY BONES.}

CASPER: There is another obscure point that I would like to have cleared up before it escapes my mind. In your remarks you have referred to the origin of the "inter-maxillary bones." I was not aware that any such exist in the human skeleton. Our medical and dental text-books say: "The maxillary bones are two in number, united on the median line of the face." If this be so, where can we locate the intermaxillæ?

Teacher: The reason why your text-books do not describe these bones is, probably, because the authors recognize their existence only in early ficetal life, and hence do not deem it necessary. But naturalists consider them very important features in zoological science, since the point where they unite with the maxillæe forms

* See Mémoire sur un Organe Transitoire de la Vie Fœetale, désigné sous le nom de Cartilage de Meckel. (E. Magitot et Ch. Robin. Paris, 1862.) 
the dividing line between the incisor and canne teeth. It seems to me that an intimate knowelge of these parts is essential to a thorongh elncation in greneral medicine, and especially in the department of dental surgery.

In furtal life the upper jaw is composed of four bones, viz, two maxillary and two intermaxillary. In each of the latter will be developed and supported two incisors - a central and a lateral: in each of the former, one cuspid and all the teeth posterior to it.

Althongh the intermaxillat are distinct bones in the human fietus, their external surface is soon corered orer with a process from each maxilla, which extends toward the median line, and becones intimately fused with the former before birtl; so that the intemaxillary suture camnot be seen on the outer side: but on the palatal aspect of these bones the suture ean always be recognized at birth, and ean often be traced even in adult life. (Flowers, Limatus Martin.)

In many animals these remain permanently as separate bones: and in hmman subjects, where the jaw is malformed, detached pieces are often found in this situation, probably owing to their arrested derelopment. (Gray.) 
By Huxley, and many other authors, these bones are called the premaxillo; these parts are also known as the incisive region, from the fact that the incisor teeth are implanted in these bones.*

Frg. 11.

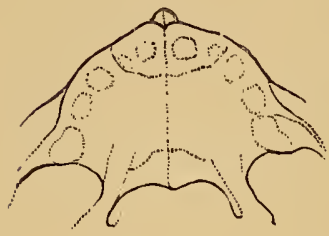

Fig. 11.- From a foetus of about four months; showing the palatal aspect of the inter-maxillary bones, and indicating the points that will be occupied by the teeth when developed; also the inter-maxillary suture separating the canine and incisor teeth.

* Perhaps it is due to the reader that I here state that the existence of these bones in the human skeleton is not an altogether uncontroverted question. I had prepared a somewhat extended article, giving a sketch of the treatment this subject has received from the pens of many anatomists and naturalists, from the days of Galen to the present. But on reflection I have concluded to suppress it, together with much other collateral matter, lest the work should be so nuch cumbered thereby as to render it tiresome or confusing to the student. The fact, however, stands unshaken, (as stated by Prof. Paul Gervais, in his work on the human skeleton, Paris, 1856,) that Vicqd'Azyr and Goethe have shown that these bones exist in the human species, as well as in all the other mammalia. The thought that GoEтHe, the great poet and naturalist, has made these little bones the object of special scientific 


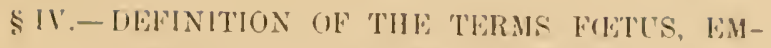
BRYO, FOLICLE AND BOURGEON.

Fraxk: I notice that sometimes you employ the term embryo and sometimes firtus. I suppose they have the same meaning?

'Tracuen: Magitot, Kölliker, Legros, Frey', Gray, and many other reputable anthors, use these terms indiscriminately, as words of the same signification. On the other hand, Dunglison, Palmer, Carpenter, Flint, and otlers, einj)loy the term embryo to designate the rudimental being during the first four months of intrauterine lite, after which they style it the fortus. Some agrain (inchuding some of the last-named anthors) (livide the period of gestation into three stages. In the first the germ is called an ovum; when this begins to assmue the apjearance of study may, in the minds of some, lend a charm to this subject that it would not otherwise possess.

It cannot be doubted, I think, that these hones originate from separate points of ossification; but they certainly, at a rule, become fused with the maxillary bones, on the extrimal surface, at a very early period of fietal life, sometimes before the fifth month; while on the palatal aspect the suture is often distinct, extending across the external alveolar process after birth. 
a body, it is termed an embryo; and abont the end of the fourth month (the time corresponding to the period of "quickening") it is accorded the name of foetus, which designation it retains until birth.

This application of the two latter terms to different periods of gestation is entirely arbitrary, and in some respects objectionable; but I shall generally adopt it, since it possesses some advantages. But sometimes it will be almost unavoidable to speak of embryonal or foetal lite, as equivalent to intraüterine life.

Frank: While you are defining terms I would like to know just what our authors mean by "dental follicle."

Teacher: The dental follicle includes the following parts: the dentine-bulb (papilla), the enamel-organ, and the sac that envelops them which is called the follicular wall. These three parts constitute the dental follicle.

The word follicle is not used here in its primary signification - a little bag or sac-but as a sac and its contents. Kölliker employs an equivalent expression, dental sacculus, in the same sense. This word follicle is also similarly employed by many other anatomists, - as 
"Gratian follicle," "Malpighian follicle," ete. Tomes, and English and American writers generally, wse the terms follicle, sac, and eapsule, as words of the same meaning. It is mitortmate that some definite and universal term is not employed to designate these associated parts of the developing tooth; but for want of such, I shall retain the term follicle in the sense that it is used by the anthors of this work. (Fig. 12 very well represents a dental follicle.)

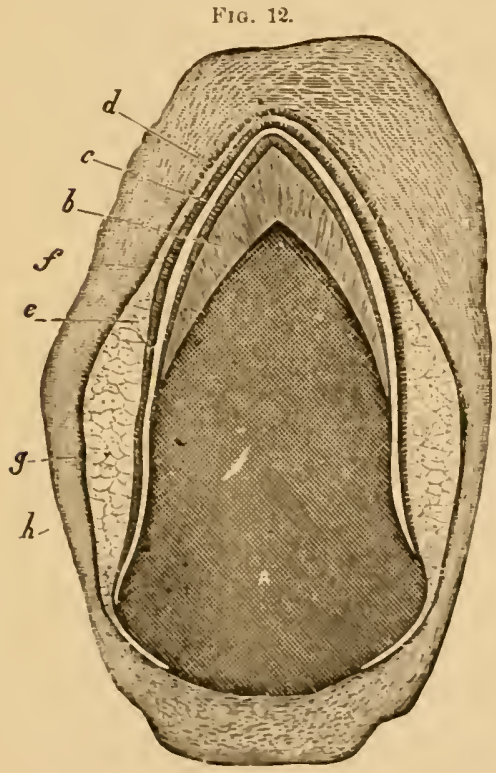

FIG. 12. - This cut is taken from the fifth elition of Kölliker's Histol'y. Though the enamel and dentine are already pretty well developed, the mass represented by the figure is still a dental follicle. It is from a feline embryo magnified fourteen diameters. $a$, Dentine-bulb; $e$, enamel-organ ; $h$. follicular wall. 


\section{TRANSLATOR'S INTRODUCTION.}

Frank: Now, one question more. You used the term "bourgeon" several times during your description of the development of the jaws. It is not a faniliar word to me, though I suppose it means about the same as process.

TEACHER: The word means bud. germ, shoot, or sprout; and the primitive outgrowths are called bourgeons, apophyses, processes, etc. It is a French word, but has become Anglicized, and may be found in your English dictionary. This term is often employed in the text as signifying enamel-germ, or enamel-bud. When the bnddings take place which develop into enamelorgans, these offshoots or buds are denominated bourgeons of the enamel-organ, or simply bourgeons.

I cannot close these introductory remarks without a word of apology for the term "cell," which has been used so freely in the foregoing pages. Now althongh this, or its equivalent, zellen, cellule, or cella, has been almost universally adopted by anatomists, the word, as applied by them, is manifestly a misnomer. And yet its primitive signification, as first used by. Schleiden, has been so modified from time to time, to correspond with onr clearer conception of the mor- 
phology and nature of the little mass of. matter thus designated, that it will require great philologieal research to discover a substitute which will be as definite and comprehensive as this term, thus moditied, has now become. Nevertheless, it is a stmmbling-block to the student. and is an example of the many defects in our terminology, that a few scientists, prominent among whom I may name Dr. Atkinson, of New: York, are making praiseworthy eftorts to remedy.

With a few preliminary remarks from our anthors, we shall now be introduced into our main, and most interesting. field of sturly. 


\section{THE AUTHORS INTHOHUCTION.}

T TIIE work we publish to-day comprises the 1 first part of a series of studies, which embrace the entire phenomena of the crolution of the dental system of mammals.

This subject, which, as you are aware. is one of the most difficult that we have to encounter in embryology, and which is still involved in very great obscurity, has been made by us the field of extensive investigations, both on the human embryo and on those of the domestic animals. By these studies we have been convinced that the phenomena presented in the series of mammifera have (except in a few minor differences) a perfect similarity in their general physiological filcts: the development of the follicle, the anatomical composition of its parts, and the role which these perform in the functions of the dental organism, are in all respects sinilar.

Our researches in this direction have been stimulated not solely hy the state of uncertainty and of controversy in which this question is 
involved, but also by the perusal of several inportant works published of late years in Germany by different anatomists,-Kölliker, Waldeyer, Hertz, Kollmann and others.

The results presented by these observers have gained, for certain parts of the question, considerable importance. They have determined some new elements that are a legitimate acquisition to science; while other conclusions which tend to invalidate certain doctrines advanced by several English and French anthors, lack, as we shall endeavor to show, sufficient precision and exactness. Besides, there are several questions which remain without any solution whatever.

It is with the hope of throwing light npon this problem, that we have undertaken this series of researches.

Following rigoronsly the physiological order, we have been led to consider successively:

1. The mode of origin and formation of the dental follicle. 2. The morphology and structure of that follicle at the period of its complete development. 3. The evolution of the tooth within the follicle.

The present memoir will be devoted to the consideration of the [two] first of these questions. 


\section{THE ORIGIN AND FORMLTION}

OF" THE:

\section{DENTAL FOLLTCLE.}

\section{CHAPTER I.}

THE CONIITION OF TIE JAWS OF THE EMBRY AT THE PERIOI) OF THE GENESIS OF THE FOLIICLE. THE EPITIELIAL RIDGE (BOIRRELET).

Thougil we do not intend to dwell the jaws at the time of the genesis of the follicle, ${ }^{*}$ still we think we ought to lay special stress upon certain points which are directly connected with our sul,ject.

As regards the lower jaw, it is known that at a certain epoch in embryonal lite. valying according to the species of animals, the maxillary areh, atholutely destitute of

* See Memoir on the Genesis and Development of the lental Follicles, by Ch. Robin and F. Magitot, in the physiological journal of Brown-séquard, 1860. 
the least trace of osseous tissue, incloses within its component elements a symmetrical cartilaginous band; and that this, uniting with its fellow at the median line, or the future symphysis, extends not only the whole length of the maxillary arch, but even to the frame of the tympanum.

This is Meckel's Cartilage, - an organ which plays only a transitory part in the development of the maxilla, and occupies the interior part of the arch. Thus embedded within the embryonic tissue, it represents, at this epoch of intraüterine life, the only fundamental elements of the jaw. (Figs. 8, 9 and 10, pp. 33-4-5.)

As to the upper jaw, the period of evolution corresponding with that which we have just described in the lower, is that at which the maxillary bourgeons have united with the median or intermaxillary bourgeon.* This phenomenon takes place in

* [These authors speak of the two maxillary bourgeons as uniting with the median or intermaxillary bourgeon. From this it would be inferred that there was but one intermaxil- 
the human embryo about the fortieth or forty-fith diy.

The two maxillary arches heing thus formed, we soon observe that in the romeled part (which will afterwarl constitute the alveolar border), there is produced a bed of epithelial aclls forming a protuberance or smooth ridge (sclillie on bourrelet), and without any fold or depression whatever. 'This lidge, visible to the maked eye, is still more manifest in a section cut perpendicular with the axis of the maxillary arch, and is composed of a thick bed of cells. It will he noticed that on its sides an eppithelial coat is formed of only a few rows (rungees) of these cells, superposed upon each other; and sometimes, even of a single row.

'The epithelial ridge is thus added to the embryonal elements before they inclucle any

lary bourgeon. They use the singular number here, probably because these bourgeons have already formed a union at their external margins, which connection tikes place a little before their union with the maxillary bonrgeons.-See Robin and Nagitot. loc. eit.. p. 9.-Trk.] 
other well defined tissues, unless it be some vessels, nerves, and muscle-fibres, in process of evolution.

This epithelial ridge has some peculiarities which are of sufficient importance to demand our special attention, and which one would not suspect from simply examining its buccal or exterior surface. In a vertical section you will notice the smooth and rounded ridge that it presents in the mouth, and which justifies the name we give it - maxillary rampart (Kieferwall of Kölliker, Waldeyer and Kollmann).

FIG. 13.

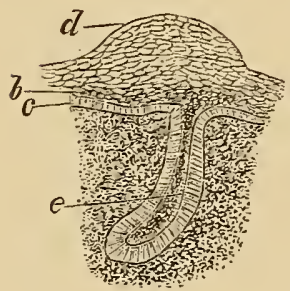

FIG. 13.-From Thiersch's preparation of an embryonic pig (copied from Frey). $d$, A mass of epithelium - the "dental ridge," "maxillary rampart" or "Kieferwall" (represented by the same letter in the preceding and following cuts); $b$, younger layer of epithelium; $c$, the deepest layer - the prismatic or columnar stratum; $e$, enamel-germ.

Beneath this external ridge a projection sinks into the subjacent elements, the outlines of which represent nearly the form 
of the letted 1; with the apes slightly inclined towat the inner side (Fig. 14, d, d).

Fit. 11.

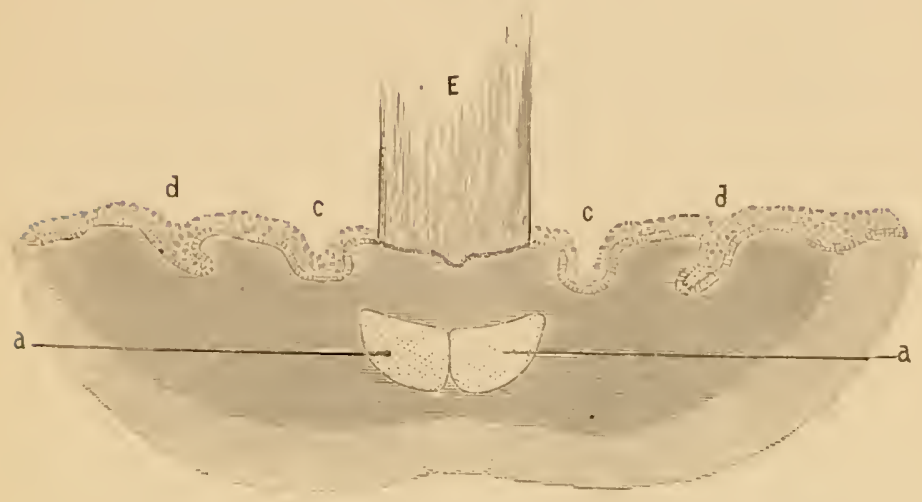

FIg. 14.-A perpendicular section taken from the mcisive region of the lower jaw of an ovine embryo (lamb), forty-two millim. in length (magnified eighty dianeters.) $d, d$, Epithelial band (bourrelet); $a, a$, transverse section of Meckel's cartilige near the symphysis; $c, c$, depression of the mucous membrane; $c$, section of the tongue. (See same letters Fig. 7, p. 30.)

CAsleR: I camnot see the appropriateness of the term "epithelial ridge," which is used so often. In the plate it looks more like a groove than a ridge.

'T'EACHIR: 'This term does not, to my mind, express detinitely the thick epithelial bed, which, though it presents on the exterual surfice of the 
jaw an eminence or ridge, yet sinks into the substance of the jaw to a greater depth than it rises above the general surface. The word used by the authors is bourrelet, which means a rounded pad, or cushion. This structure was for a long time supposed to be cartilaginous in its nature, and hence called cartilago dentalis, until Raschkow discovered its epithelial character. M. Guillot (1859) named it the odontogenic part, or the generating part of the teeth; our anthors speak of it frequently as an epithelial band, and we will hereafter so denominate it.

In a vertical transverse section this band is represented, as has been stated, by the letter $V$, with the apex bent a little inward. Now fill this with epithelial cells, and heap them up, and you have a tolerably accurate idea of the epithelial bourrelet or band. In other words, make a groove the entire length of the jaw, shaped as just described, and fill it "heaping full" of this cellular mass, and it also will represent the epithelial band, as seen in fig. 15 .

FIG. 15.

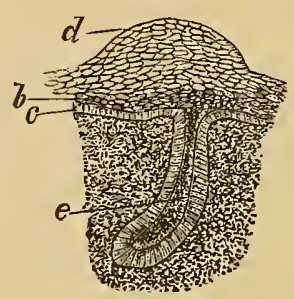


Thus constituted, the lommet forms, in reality, a contimuons epithelial hand, nearly vertical, the whole length of the alventar loreler: It always exists in the embryos of man and the higher mammalia, and is even found on some parts which will remain deroid of teeth, as in the bat of the soliperls.

Frank: "The bar of the solipeds" is too much for me; soliped, single foot. I did not know there were any one-footed animals:

CAsper: I know that the name soliped is applied to the races of animals that have a single hoof-as the horse and ass - but I an stuck on the "bar."

Tesches: In animals, that interval between the "tusks" and the molars, which is destitute of teeth, is technically called the bar: and though the band extends along this portion of the jaw, it is umprodnctive, and becomes atrophied and absorbed, as we shall see further on. The more elegant term diastema is quite commonly employed to denote this racant space between the teeth of the soliped, as well as those that may oceur in the jaws of other animals. 
I will give you the substance of a very interesting foot-note from the pen of Dr. Pietkiewicz (a former pupil in the laboratory of Prof. Robin) on the Rudimentary Dental Organs of the Ruminants. It has been inserted here with the indorsement of the author's of this work; but owing to its great length I shall give only a brief summary of its contents, as published in the "Transactions of the American Dental Association,".1878:

You are aware that there is a wide-spread belief, which had its origin in the announcement of Goodsir, in 1839, that rudimentary incisor teeth nay be found in the embryonal jaws of Ruminants. This statement, founded upon certain anatomical appearances, was seized upon by Darwin, Hæcke], and other scientists, to sustain their views regarding the charges that had taken place in the successive generations of animal beings; and thus the theory received additional credit and a fresh impulse, until it has now become the prevailing belief, that the upper jaws of the foetus of ruminants contain germs of teeth; which, however, disappear before, or soon after, the birth of the animal.

This conclusion of Goodsir, which was never carefully verified, has recently been severely shaken, if not entirely overthrown, by the researches of Dr. Pietkiewicz.

He says, that in attempting to verify the statement of Goodsir, which had obtained such extensive circulation and credit, he made experiments upon a series of embryos of cattle and sheep, taken in large numbers, from the 
earliest period of intrailterine life until they had attained thirty centimeters, or one foot, in length. In this series of investigations, he not only never witnessed the presence of a dental germ, but never found even a trace of the epithelial lamina.

He further states, however, that in the emmencement of his work he was led into an error by the deceptive appearance of the sections made entirely from the anterior portion of the jaws: for in these he found on each side of the median line an epithelial sae, which extended from the mucous membrane into the depth of the jaw, and which appered to constitnte the commencement of dental germs, such as Goodsir undoubtedly conceived them to be. No difference was observed between the epithelium of this sac and that of the mueous membrane, of which it appeared to be a depression. 'The Malpighian layer constituted its outer investment, while in its interior was found pavimentous epithelium.

From this appearance. he thought one could easily conceive how Goodsir might have been led into the belief that he had discovered dental germs. But in continuing to make sections from these jaws in a postcrior direction, he found that the little sac assumed the form of a circular canal, and approached the mucous membrane of the nasal fossit. Around this canal appeared a cartilaginous cornet. and in the upper part was a mass containing ressels. From this he recognized the organ of Jacobson. There was absolutely nothing, lie says, that could be, even remotely, compured to the germs of the ineisor or eanine teeth. 
The form of the epithelial band is the same in the different species of animals; and while it presents its broadest aspect on the alreolar ridge, it grows thinner, and at the same time hends a little inward, as it descends into the subjacent tissues; so that its internal or lingual fiace presents a concavity, and its labial or buccal face a convexity.

Though the deeper extremity, or apex, of the band is blunt and rounded in the early stage of (levelopment, it becomes very shar') at the moment the first trace of the follicle appears.

This band is composed of the same histological elements that constitute the epithelial coat of the oral mucous membrane,that is to say, of nucleated cells, rendered polyhedral in form by reciprocal pressure; and that portion which penetrates the tissues of the jaw is bounded by a continuous layer of prismatic cells. The cells that compose the center of the band often 
prexent at their lenders that denticulated arramgement which laks heeen noticed hy anthor's in the cells of the epidermis, and hy which the elements interlexes with.

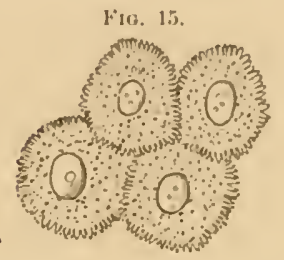
each other: [Cells elesoribed in the Introduction, as the "imbricated," "prickle," etc., to which list we will and here the explieatives "thom!" and "heckle." Fig. 15.]

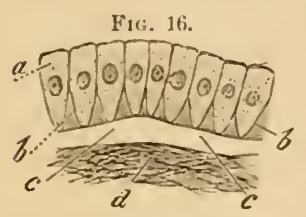

As regands the prismatic layer, it does not difter firoun the stratrm Malprigheii, from which it is directly derived. [Fig. 16, b. Frem Fere! ]

Finen the preceding consiclerations it is sentl that the epithelial hand, which we have just described, is simply a prolongation of the epithelial tegumentary layere (ammete) of the month, which, in sinking into the eme myonic tismes of the jalls, fimms for itselt, so to speak, al groove which it exalctly fills. Now; when the embryonal jaw is sub- 
jected to a prolonged maceration, the band may become spontaneously detached, thus leaving an empty groove; but at no epoch, in embryonal life, can there be found, on the surface of the alveolar border, any depression, sinking, or perforation whatever, when these parts are in a normal condition.

The well-known theory of the evolution of the teeth advanced by Goodsir in 1837, and afterward adopted by most authors, was founded on a certain mechanism, which consisted in the formation of the follicular sac at the expense of an exterior depression of the oral mucous membrane. 'The detach. ment of the epithelial bed by maceration may, doubtless, account for this dror; but nothing exists in the normal state of the jaws to wariant any such conclusion. The theory of Goodsir is, therefore, absolutely without foundation in fact.*

* [For a long time Goodsir's theory of the evolution of the teeth was held to be correct, and his verbal and pictorial representations were copied into our standard textbooks on anatomy and physiology, both medical and 
dental; and even lïlliker, up to his fourth edition, horrows from that anthor the cuts illustrating this stage of evolution. Goodsir " believed that, at an early period of frotal life, there appears a continuous open groove, running round the whole circumference of the jaws; that from the bottom of this groove there arose isolated and uncovered papillar, corresponding in number to the milk teeth; that these papillip become covered in by the deepening of the groove and the meeting of its two edges over their tops, whilst at the same time transverse septa were formed, so that the several papillie become enclosed in their own separate follicles. "-Tomes' M/an. of Dent. Anat.

"This theory of Cioodsir was vigorously attacked at a later date in works of the French histologists Guillot, and Magitot and Robin. According to the latter, the toothsacs, dental germs, and remaining parts are developed, in the first instance, within the submucous connected tissue (subdermis), quite independent of the epithelium or nucosus."-Fry. Tr.] 


\section{CHAPTER II.}

THE EPITHELIAL LANINA, AND THE GENESIS OF THE ENAMEL-ORGAN.

$W^{\mathrm{E}}$ have seen that the part of the epithelial bourrelet, or band, which sinks into the tissue of the jaw, presents two faces - an external convex and an internal concave one; and that it extends the entire length of the alveolar border. Now, as soon as the development of this organ is completed, a thin process shoots out from its internal face, which we shall designate the epithelial lamina. (Figs. 17 and 18, E E.)

This lamina is a continuous process, extending the whole length of the epithelial band, from which it emanates about midway between its apex and the epithelial layer (sometimes a little nearer the latter), 
and appears to he a kind of diverticu* hum (or inflexion) of the hamel itselt. It

Fig. 1\%.

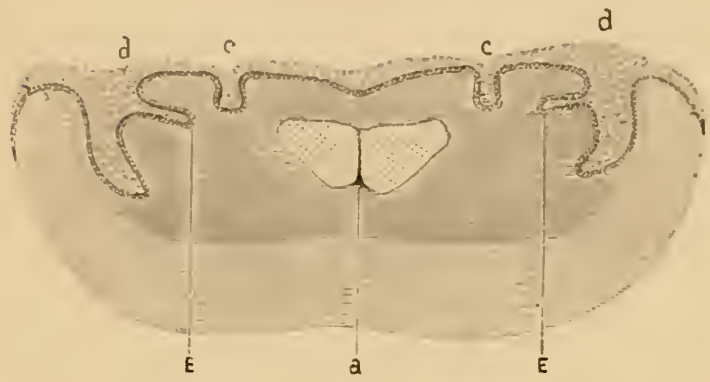

Fic. 17.-Vertical section of the anterior portion of the lower jaw of an ovine embryo measuring 59 millimetres. a. Showing the section of Meckel's Cartilage; $d$, epithelial band (or bour.elet); $c$, fold in the mucous membrane; $E$, pithelial lamina. These letters refer to the same parts in the foregoing and following figures.

is somewhat flattened from above downward, and its rounded extremity is slightly lent in the form of a crosier. (Fies. 1S, F.)

'The clements of the lamina ane of the same character as those which compose the hand, riz., polyogonal cells inclosed hy a contimunus layer of prismatic (colls. As derelopment atrances, larege polygonal cells make their appearince in the thickel portion of 
the lamina, similar to those found in the band, or external epithelium. These arrangements are important to be noticed; for, as will be seen hereafter, the prismatic

FIG. 18.

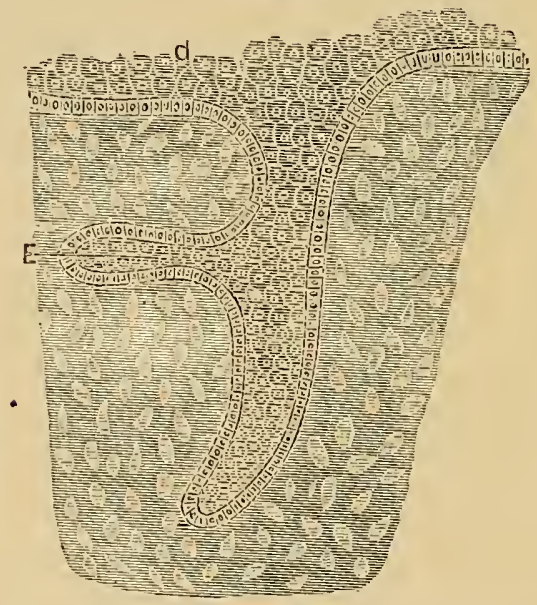

FIG. 18.- Transverse section of the left branch of the lower jaw of an ovine embryo (65 millimetres in length), magnified 260 diameters. This and the preceding cut show the arrangement of the elements of the epithelial band, and also the epithelial lamina.

$d$, Epithelium of the nucous membrane, extending nearly vertically into the jaw and constituting the band and the lamina. E, Epithelial lamina, emanating from the band. The band and lamina are surrounded by the embryonal tissue of the jaw. This portion of the engraving is faulty, in that the nuclear elements are lighter than the surrounding mass, whereas they should appear darker. 
elemests which form its outer investment are never fomml in the dilleris of the lamina, nor in those of the eppithelial cord which is derived firom it.

The enamel-origan - the tirst trace of the dental follicle - originates firm points upon the fiese extremity of this laminal. They show themselves, at first, as slight tubereles arranged at intervals along the mangin of the lamina, and corresponding, in number and situation, to the teeth that will be dereloped in the first dentition. To these protuberances we give the name of primitice bourgeon of the follicle (the first follicular budding, or lud).

[In a foot-note these authors give their theory of the origin of the supernumerary teeth; but, as Dr. Magitot (the surviving anthor of this work) has since modified his views in relation to this phenomenon, a mere statement of the theory advanced by them will here be sutticient. Drs. Legros and Magitot maintained that the supernumerary teeth originate either from the epithelial lamina, from supenumerary buddings arising betreen the normal number: or that they are off-shoots from the epithelial cord. In the first ease the development of these teeth would be preciscly similar to that of the decituous tecth: in the 
other, to that of the permanent teeth, with the exception of the first molar.

The present views of Dr. Magitot upon this subject (as recorded on pp. 36-7 of his treatise on the Anomalies of the Teeth, 1877,) are in accord with those previously advanced by Kollmann; and are based upon the well-known fact, that when the epithelial cord or neck, which connects the enamel-organ with the epithelial lamina, becomes severed by the closure of the follicle, the cells, of which the cord is composed, multiply to a greater or less extent at their severed extremities,--sometimes in great abundance. These epithelial proliferations sometimes continue adherent to the remains of the cord, and to the follicle itself, until they are absorbed; and sometimes considerable masses become detached, and, assuming various forms, wander into the depths of the jaws (Fig. 19). These epithelial proliferations, according to Kollmann and Magitot, may become the enamel-germs from which the supernumerary teeth originate.

Now, in order that a tooth may be produced, a supernumerary dentine-papilla must be provided for this adventitious enamel-organ. This would result as a natural consequence, if the theory advanced by the translator of this work in a recent Report on Dental Physiology, before the American Dental Association, is correct. (See Trans., 1879, pp. 56-57). In this paper it was maintained that dentine-papilla may originate from any point of the dentinal sheet of tissue (as described by Dursy), with which the epithelial mass comes in contact; that it is solely through the influence of the enamel-organ upon this tissue, that the development of a dentine-papilla is induced. If 
Fiti. 19.

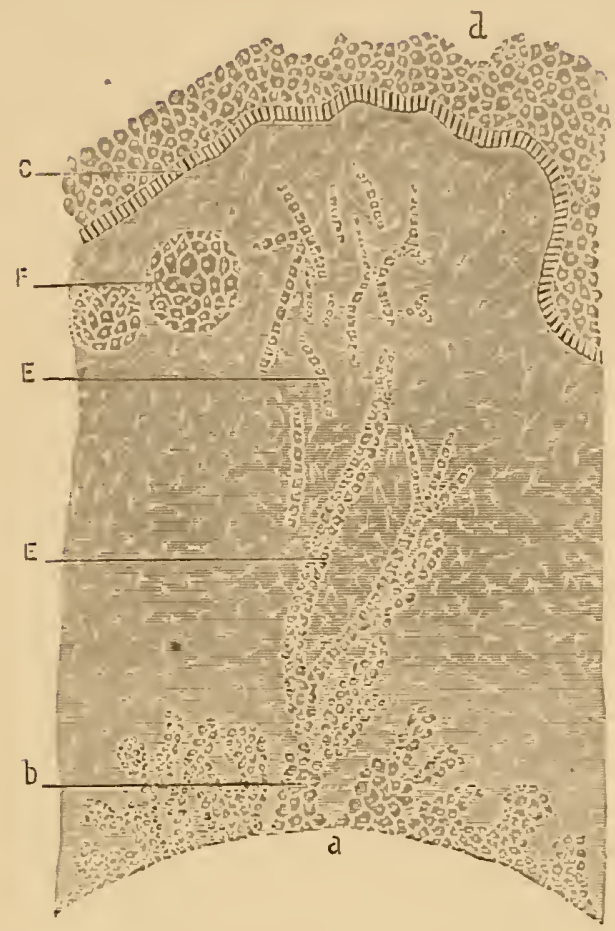

FIG. 19.-Taken from a bovine embryo. magnified 100 diameters. This section is taken after the rupture of the epithelial cord, and shows the epithelial proliferations that occur in this region at this period of evolution. The cut represents the territory between the wall of the follicle (a) and the mucous membrane (d).

b, Epithelial buddings from the follicular wall: $E, E$. buddings ant debris of the cord; $F$. globular misses from the epithelial lamina. 
this be true the origin of a supernumerary dentine-papilla is readily accounted for; while otherwise, special papillæ must originate independently, and coincidently with the supernumerary enamel-organ,- - a circumstance that does not come within the range of probabilities.

Thus, also, it seems to ne. we find a rational and satisfactory explanation of the origin of those families of dwaried teeth found in dentigerous cysts.-Tr.]

This bourgeon retains its connection with the lamina, from which it is a direct derivation, by means of a slender cord or neck, which gradually lengthens as the terminal mass increases in dimensions.

During the whole course of development this bourgeon constitutes the enamel-organ; while the neck, in its progressive lengthening, only serves as a temporary bond uniting it to the lamina.

At its first appearance the primitive bourgeon presents a nearly spherical form (Fig. 20, E), and is composed of an external layer of prismatic cells (a continuation of those of the lamina), inclosing a mass of polygonal cells; the latter being always 
lesis in dianeter than those containerl in the lamina.

[itic. 20.

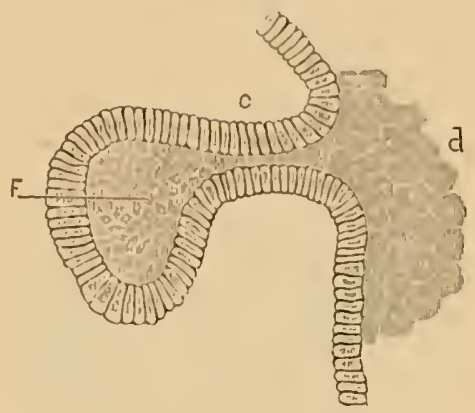

Frc. 20.-A section of the epithelial lamina taken from an embryonic lamb, a little older than that from which Fig. 18 was taken. (Magnified 350 diameters.)

c, I'rismatic or columnar cells, - a continuation of the lowest liyer of the Malpighian stratum; $d$, large polygonal cells. of the epithelial band (boumelet); $E$, smaller cells of the epithelial lamina. This lamma presents an enlarged extremity, and this enlargement represents the commencement of the enamel-organ.

[The prismatic and the polygonal cells are beantifully drawn in this figure.]

(Şee advancing stage of development, fig. 21.)

Let us here ald that during the progress of evolution these elements (inclosed in the prismatic investment) molergo a modification wherehy they are transformed into stellate borlies-a phenomenom that neres 
occurs in the cells of the cord or of the lamina. The disparity in the size of these cells, together with the morphological changes they experience, seems to us sufficient to establish, from this period, a very

FIg. 21.

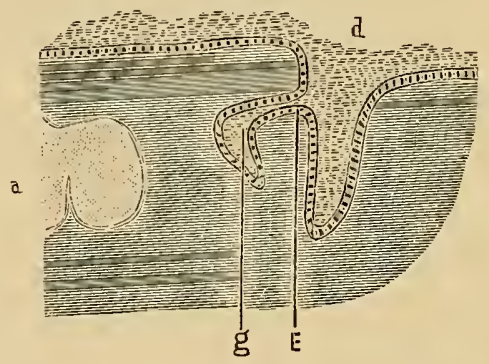

Fig. 21.-A section taken from the lower jaw of an ovine embryo (left side), measuring 72 millimetres. (Magnified 80 diameters.)

$d, E$, Same as in the preceding figures. $g$, Commencement of the enamel-organ.

clear distinction between the constitution of the lamince and that of the bourgeon which emanates from it. We would emphasize this point, from the fact that the more recent authors that have written upon this subject have confounded these two parts with each other. 
These diflerences, howerer, will he moles clearly mantest during the progress of (200lution, when we shall find the elements of the boumeon [enamel-organ] undergoing at series of important changes; whereas those of the Jamina will invariably retain their original appearance.

In continumg its evolution, the primitive bomrecon, which wats at first spherical, becomes somerhat cylindrical, thomgh it still pursues a horizontal course mutil it has become noticeably lengthened, when, by an alnupt inflection, it takes a rertical direc. tion, and sinks into the depth of the jaw. Thus extending its course, the cord acquires a length which raries acoording to the species of animal, hesides molergoing certain secondary inflections. In man, als also in the don, the cord always remains short. amd in the solipeds it is still shorter. In the calt and in the lamh-amimals that are particularly firorable for these studies -it desclibes diver's mululations: hut we 
have never observed in the primitive cord that spiroid arrangement described by some authors, and for which, as we shall see, the secondary cord (that of the permanent teeth) is so remarkable.

'These differences in the length of the primitive cord are explained by the disposition of the special parts; and determined, on the one hand, by the species of animals, in which the jaws have a greater or less vertical height; and on the other by the nature of the future teeth. One readily sees how the cord of the follicle of a permanent tooth ongt to be longer than that of the temporary, since it must accommodate itself to the longer passage it must make from the place of its origin to its terminus beneath the follicle of the temporary tooth.

The primitive cord, in the course of its progress, presents, moreover, some peculiarities worthy of notice. These are the phenomena of lateral buddings, which give rise

* See Kollmann, loc. cit., Taf. XIV, Fig. 2, v. 
to small romuded nodules, in the form of valloosities, which, in their arlansement, le. semble an irregular chaplet. (Fig. 22, F.) There little masses are composed exclusirely FIG. 2?.

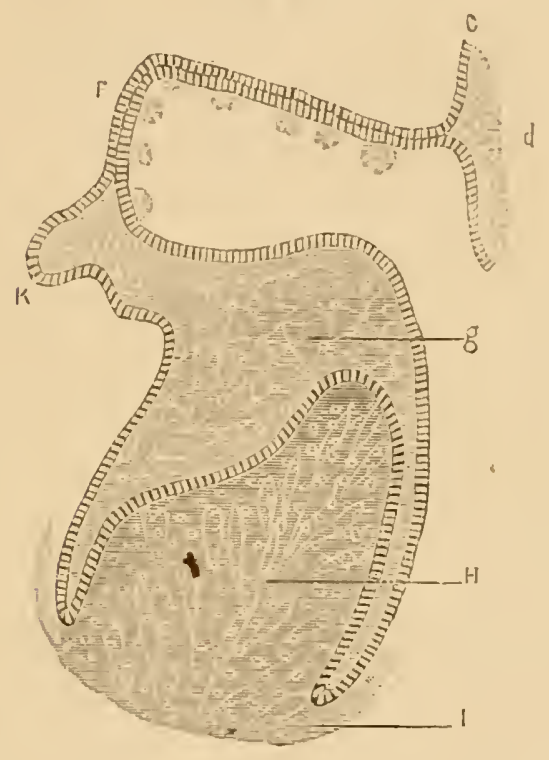

Fic. 22.-Taken from a section of the lower jaw of an ovine embryo, measuring 82 millim. in length. (Magnified 260 diumeters.) $c$, Oral epithelium; $F$, epithelial cord and the "varicosities" referred to in the text: g, enamel-organ; $H$, dentine bulb; $I$, follicular wall rising from the base of the ${ }_{2}$ bulb; $K$, bourgeon trom which the follicle of the permanent tooth will emamate. 
of small polyhedral cells; analogous to those contained in the cord itself.*

It is from these masses that, at a later period, after the cord is ruptured, those numerous epithelial prolongations spring, which will be considered hereafter. It is hardly necessary to say that we do not here confound the buddings, just described, with that special production from which the cord of the secondary follicle originates,a point to which we will return further on. After the cord has changed its course from a horizontal to a vertical direction, its extremity, which has already become enlarged and club-shaped, acquires still greater dimensions. This results from the multiplication of the polyhedral cells which compose most of its mass, and from the

* [The cells referred to as being in the cord are not. shown in the figure. Only the prismatic layer, which forms the outer coat, is represented here. The cord may be compared to a tubular gland, the walls of which are composed of a layer of prismatic cells (a continuation of the stratum Malpighii), and the inclosed contents, of small. polygonal cells. Tr.] 
prismatic cells that form the smromeling layer, whose mumlers inclease in the simme proportion. This epithelial borly thus occupying the deeper tissue of the jaw soon assumes a somewhat spherical. form; the superion pole corresponding with its point of comnection with the cord, while the inferior pole points toward the bottom of the jaw, inclining more or less toward the lingual side. This mass represents the enamel-orgum as fully devoloped. Shortly afterward the inferior pole hecomes slightly compressed toward the center of the enamel. organ, which results in the formation of a concavity in its lower or deeper extremity; and the mass then assumes a shape resembling a loorl or (ap), but still retaining its comnection with the cord.

This phenomenon of compresion coincides with the appearance of a new olgan in the jaws, the dentinclunlb [dentine. papillic]. This, in fiact, originates at the inferior pole of the enamel-organ, where 
the compression takes place. It first appears as an opaque point, but it soon assumes a conical form, and its summit produces and occupies the corresponding depression in the enamel-organ.

This reciprocal adaptation of the two organs, which takes place from the first appearance of the dental bulb, continues throughout all their subsequent phases; the enamel-organ always covering the bulb, and exactly fitting its contours; whatever may be its form, or the form, number and disposition of the divisions it may present. No connection of tissue, however, exists between the two organs at any stage of development. Dissectious of these parts, their maceration in coagulating liquids, as well as the examination of sections, all establish this fact beyond question. This simple juxtaposition of the surfaces of these two organs ceases, however, at the base of the bulb, where the enamel-organ turns back upon itself with a rounded border. (Fig. 22.) 
If we now examine the compration of the enamel.organ, at the period of developmont represented in lig. 2.2,-- sal al ant the fifterenth week of the human embiyo, J we find that the prinitive elements (the polyeonal cells which ocenpy its central portion, and the prisuntic cortical layer, ) have mulergone notable modifications. IV discover, in fitct, that the midelle lexgion of this orgatn is oceupied by some elements of a new form, esirentially differing in appeantunce from that of the original cells. These are stellite bodies, composed of a central muclens, str1-

F16, 23.

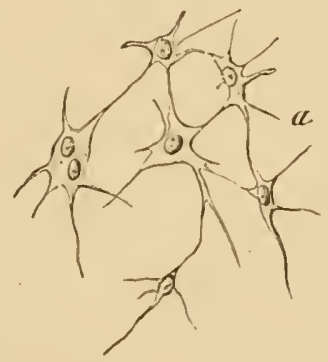

Fu. 23.- Stellate cells of the emamel-organ. (Diagrammatic, from $F, r y)$. These cells are also very well shown in the preceding figure. 
rounded by a transparent or finely granulated mass, which ramifies and inosculates with the neighboring elements. (Figs. 22-3.)

These star-shaped bodies occupy at first only the center of the enamel-organ; those near the periphery preserving their original polygonal form, but becoming stellate in proportion as the dimensions of the organ increase. It will be noticed, however, that the anastomosing processes are always much longer and more ramified, as the cells are situated nearer to the central portion; while in the vicinity of the periphery it is somewhat difficult to distinguish these processes, as they are here only rudimentary. The elements thus described are immersed in a translucid amorphous mass, coagulable in acids, and having the consistence and appearance of the white of an egg.

These starred bodies - or "stellate cells," as they are usually termed,- are formed directly at the expense of the polygonal elements composing the internal mass of 
the entamel-organ. The process is as follows: The sulstance mentioned ahore interposes itself little by little between these originally small polyherlarl cells, and thus their walls lose their mutual contalet, except at certain points where they still cohere. As a rirect result of this phenomenon, the primitive polyonal cells exhihit a number of depresions extenling from their exterior surfice toward the center, giving them their stellate appearance.

From this transformation the prinitive cells wonld lecome entirely insulated by the intervention of this new mucous formattion, were it not for these connecting pro. cesese, which give to this organl, as a whole, it- peculiar reticulated appearance, and to each cell its stellate form. It is a remarkahle tiuct that no line of juncture cam be discovered where these cells alre comnected with each other, the varions l'e-agents failing to disclose the least tralce of it, so effectually have these parts been cemented togrethers. 
According to this theory, the stellate arrangement of the "pulp" of the enamel-organ (the intimate composition of which we do not purpose to describe in this memoir) re. sults from a simple modification of the form of the primitire polygonal cells,-a change which they have undergone passively, as it were. These elements of the enamelorgan, notwithstanding their stellate form, must be regarded, therefore, as absolutely epithelial in their nature. The mechanism of this transformation, however, differs materially from that given by Kölliker, * and after him by several other anatomists, who contend that these primitive cells might take this stellate form spontaneously. Our opinion, however, is in conformity with that of Waldeyer, who was the first to. properly examine and describe this phenomenon; though Huxley, at a much

* Human Histology, French trans., 1869, p. 497.

$\dagger$ Untersuchungen ï̉ber die Entwicklung der Zühne, Zeitschr. f. rat. med. 1865.

$\ddagger$ Quart. Journal of Microscopical Sc., 1854, pp. 55-56. 


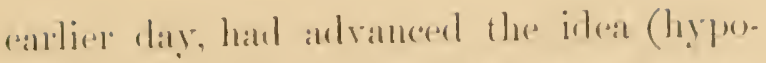
thetically, it is true, ) that the (manmel-organ had an epithelial origin; lut le did not indicate the mode wherely the transformattion of its elements was affected."

Now as to the prismatic cells: during the

* The epithelial nature of the enamel-organ had not till recently heen accepted in France; lut its elements were described as stellate fibro-plastie bodies ( Robin and Mlagitot, loe. cit., p. 60). This conclusion was based, howerer, solely upon the form that these elements present; and the same argument may be used to controvert this opinion. It is this: that in the enamel-organ the borders of these cells, between the radiated filaments which are drawn out from their periphery, are aluays concure, while in the stellate filro-plastic bodies these borders present plane or convex surffaces alternating with those that are concare.

[The student must not infer from the above that Huxley was the first to advanee the illea that the enumel was of epitheliel origin; for this opinion was held hy physiologists long before his day. The discovery accredited to Huxley is this: that the cells, constituting the intermul mass of the enamel-organ (the reticular portion surrounded by the stratum of prismatic cells), are only metamorphosert epithelial cells. Heretofore listologists believerl these to be stellate conneetive-tissue cells: but the peripheral layer was then. as it is now. admitted to be composed of epithelial cells. 'Tr.] 
early stage of evolution, we have found them identical in character and in dimensions on all parts of the periphery; but the moment the enamel-organ assumes a new form, produced by the development of the bulb, this stratum undergoes some important modifications. At this period, in fact, the cells of that portion of the cortical layer, which occupy the concave face of the enamelorgan, and which consequently lie in contact with the dentinal bulb, begin to increase in length; while those constituting the convex surface of this organ sensibly diminish in size. This difference in the dimensions of the cells occupying the two segments of the prismatic stratum or cortical layer manifests itself more and more during the progress of follicular evolution; and, as we shall see hereafter, the external layer [" external epithelium of the enamelorgan"] disappears long before the complete atrophy of the enamel-pulp; while the other [the "internal epithelium "] still 
remains to pertorm the important functions asigned to it, namely, the formution of the encemel.

The prismatic cells of the concave fice of the enamel-organ [the entmel-cells, or ameloblast., ] offer some peculiar character.

* [The term ameloblast is compounded of A mel (from the French '́mail), enamel; and blast (from the Greek blastos), germ. This compound word has recently been introduced into our nomenclature by Prof. Fames, of St. Louis; and owing to its enphony, its concise and definite expression, and its general relations to the terms osteoblast, odontoblast and others, it ought, as it seems to me. to be adopted by the dental histologist. It will certainly facilitate the description of the parts to which it is applied, and obviate the repetition of long descriptive phrases. I shall, therefore, follow the lead of Dr. Black, and whenever it seems best shall substitute this new term for phrases of equivalent meaning that may be found in the original. The ameloblasts are the enamel-cells. They constitute the prismotic layer of Legros and Magitot; the internal epithelium of Kïlliker; and the adamantine membrane of Raschkow: namely, that sertion of the strutum Malpighii forming the peripheral layer which lines the concate fuce of the mamet. organ, and lies in immedinte contact with the dentine-bulh. The other section of this stratum corers, or rather constitutes, the convex surfice of the enamel-organ, and is generally known as the external epithelium. It has probably been 
istics, to which we will now call your attention. Originally identical with those of the [lowest layer of the] Malpighian stratum, from which they are directly derived, these cells, besides increasing in length, experience some important changes in form. The extremity that is directed toward the center of the organ, becomes long and slender, forming processes which unite with or are continuous with the filaments that proceed from those neighboring cells which constitute the portion of the enamel-organ. known as the stratum intermedium.* The

previously noticed that the peripheral layer has been divided into two sections. This has been done simply for convenience of description, there being no anatomical division between these two portions; the cells being alike and contiguous, although at a later period they experience those dissimilar modifications that are fully and clearly described in the text. Tr.]

* [As this portion of the enamel-organ is only incidentally mentioned in this work, a few words of explanation may not be out of place here. It might with propriety be termed the stratum of Hannover since he is its accredited discoverer. This "stratum intermedium" is not represented in any of these cuts, but it consists of a 
opposite or preripheral extremity; that is to say, the bros of these colls, presents the regular prismatic form of a hexagon. ( Fig. 24.) If we now examine an molermuged Fic. 24.

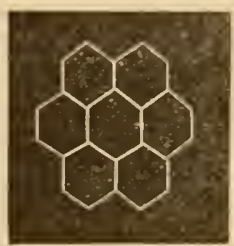

[Fig. 24 represents the basal aspect of a layer of ameloblasts. Tre.]

layer of these prismatic cells, or ameloblasts, magnitied about 400 dianeters, we shall find that the firee margin of this layer (that is to say, the pant that corresponds to the

few layers of celis that still retain nearly their primitive form, and lies between the laser of ameloblasts and the stellate portion of the "enamel-pulp." Prof. Tomes (in his Man. of Dental Anat., p. 125) describes it thus: "The 'stratum intermedium' consists of cells intermediate in character between those of the bordering epithelium and the stellate reticulum; they are branehed, but less conspicuously so than the stellate cells, with which on the one hand they are continuous, on the other with the enamel cells." The special functions of these cells is 
- base of these cells) appears clearer than the bodies of the cells themselves, and in fresh preparations seems like a continuous line. If, lowever, a like examination be made of some hardened preparations, or if careful means be taken to detach this marginal line, which the edge of a section of the plateau represents, from the base of the cells, it will be found that it can be subdivided into as many sections as there are cells in the layer. And yet some preparations may be met with, in which more or less of this clearer line becomes detached in the form of a shred of ribbon. It is this strip, which is evidently made continuous

questionable. Waldeyer believes that, since " the enamel cells may be frequently seen to be connected at their lower extremities with the cells of the stratum intermedium, a multiplication of the enamel-cells from the cells of this stratum in the direction of their lengtb. may be admitted to occur" (Stricker's Hist., p. 334); an opinion shared by Hertz and the author first quoted, but differing from that of Magitot and Kölliker. A further description of these cells would inore properly come under the head of Development of the Enamel. Tr.] 
by artificial means, that has given rise to the hypothesis that a membrane invests or lines the concave faces of this stratum of cells; ameloblasts. TWe shall sace, morecover, in examining these peculiatities in detail, that this alpleanance is not specially and exclusively confined to the cells of the enamelorgan, since it exists wherever we find the prismatic cells provided with what has heen termed a platean. The prismatic cells of the intestines are known to be thus sup. plied. Now it happens, that, whether this platean remains adherent to each cell separately, or whether it hecomes atherent to those of the neighloring cells, so that a strip may be detached presenting the appearance of a true membrane, depends entirely upon the mode of treatment to which the preparation is smljected.

Frank: This, I infer, is the basement, or preformative, membrane?

Teacner: The edye of the tissue that forms, in section, the clear line, is not the same struc- 
ture described (p. 17) as the membrana praformativa of Raschliow; the membrane here discussed is situated between the latter tissue and the layer of ameloblasts; and these two structures, thus lying in apposition with each other, correspond with the "double pellucid layer" mentioned by Dr. Black, in his report on Fistology (p. 72 Trans. A. D. A., 1878), in which he says: "Just before the calcification, and even before the odontoblasts make their appearance, the ameloblasts, and the tissues of the pulp, are separated by a well marked double pellucid layer; which, in section, appears as a double band," etc. The two white parallel lines A, A, fig. 25, represent this "double band"; the upper one being the tissue here described by our authors, and which is identical with the membrana prceformativa of Huxley; while the lower one represents the basement membrane of Todd and Bowmann, and the membrana proformativa of Raschkow. The clear line referred to in the text as being seen at the edge of a section of a layer of enamel-cells,- namely, the upper line of the double pellucid zone, or the preformative membrane of Huxley,-is formed by the artificial union of the operculc that cover the dentinal extremities of the ameloblasts. 
The figure below is an ideal representation of a dental follicle before it has lost its connection with the epidemis. The object of this cont is to show the relation of the basement membrane and the two different structures (one of which is

FIG. 25.

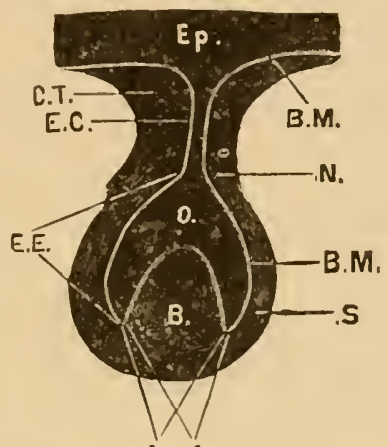

A. A.

Fra, 25.-W $M$, basement membrane; $N$, neck; $s$, sac or follicular wall; $O$, enamel-organ; $B$, bulb; $E E$, external epithelium of the enamel-organ and the basement membrane; $E C$, epithelial cord; $C T$, connective tissue surrounding the enamel-organ; $E_{p}$, epidermis or oral epithelium.

The parts embraced between the points where the divergent lines $A A$ terminate, are:-(1) the concave face of the enamel-orgm, lined with al liyer of ameloblasts. or the "internal epithelium "; $(2)$ the membrana preformativa of Huxley, or the tissue composed of the basal coverings of the ameloblasts; (3) the membrana prieformativa of Rasehkow, or the basement membrane; (4) the dentine-bull, itself. Viagrammatic. 
known as the membrana præformativa of Raschkow, and the other as that of Huxley) to the adjacent parts. The white line terminating on either side of the upper portion of the figure represents the basement membrane, and separates the epidermal from the dermal tissues. The mass embraced within the walls of this devious line is composed of epithelial cells; that found on the other side of this line belongs to the dermal tissue. Now, that portion of the membrane represented by this line, which passes between the enamel-organ $(\mathrm{O})$ and the dentine-bulb $(\mathrm{B})$, and which constitntes the peripheral layer of the latter (A A), is said to assume important functions in the development of the dentine; and hence was denominated the membrana præformativa by Raschkow; a name it still retains, although, as to its nature and office, physiologists are not agreed. The upper line running parallel to this membrana preformativa of Raschkow, as before stated, represents the membrana preformativa of Hnxley; and by him, Schwann, Kölliker, Magitot, and some others, special functions have been assigned to it in the formation of the enamel. But you must not infer from what has been said that the last named anthors precisely agree as to 
the nature of this membrane, or as to the mode of enamel-development, amelification.

Caslik: 'This term memhrana preformativa is about as equirocal as that of mucous memhrane, for I have already fomd it applierl to three diflerent tissues, one of which is said to line the walls of the pulp-chamber.

Teachir: 'The latter comsists of a layer of odontoblasts, and is generally called the membrana eboris. But we must discontinne for the present the discussion of these tissues, the mature and functions of which (and even the existence of some of them) are still matters of dispute. Nevertheless, these histological fincts or appearances will be found useful hereafter in studying the development of the enamel and dentine.

As to the muclens of the prismatic cells [the ameloblasts] of the enamel-olgan, we find that its position ranies in relation to the ends of the cell, accolding to the period of devalopment; at tirst it is about equidistant, hut it afterward appears to move toward the tapeling extrenity. This apparent clange of place, howevere, is not real, 
but results from the more rapid growth of the dentinal end of the cell (which is remarkably active after the development of the bulb), thus causing the nucleus apparently to move away from it. This difference in the derelopment of the extremities of the ameloblasts is especially remarkable in the enamel-organ of the incisors of the rodents, in which these elements attain to great length. 


\section{CHAPTER III.}

ORIGIN AND FORMATION OF THE IENTAL BULP. AND OF TIIE FOLLICULAR WALI.

A we have just seen, the enamel-organ I soon loses its spherical form and acquires the appearance of a hood or cap; and this change in form is contemporaneous with the appearance of a new component part of the follicle,- the dentinal bull. A slight opacity appears on the point of em. bryonic tissue of the jaw, that corresponds to the depression in the enamel-organ. This opacity is dne to the production of new elements, which are grouped in such a mamner as to form at first a little rounded nipple of hemispheric form, the convexity of which corresponds exactly to the de- 
pression or concavity of the enamel-organ. (Fig. 26, H.)

FIG. 26.

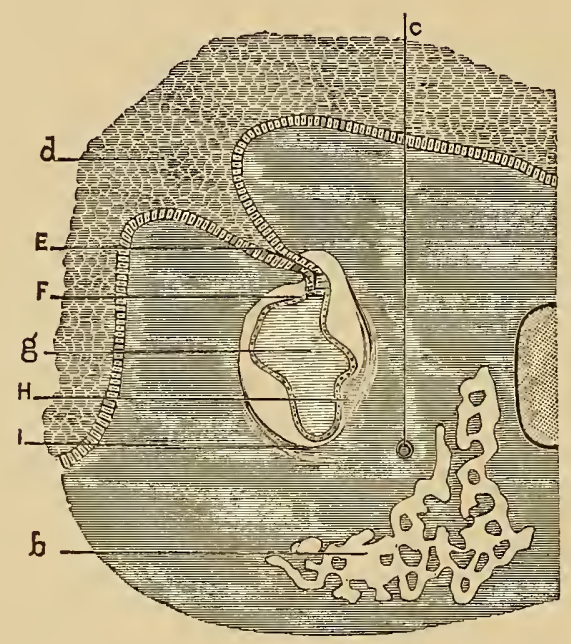

FIG. 26.-Vertical section taken from the incisive region of the lower jaw of an ovine embryo, measuring 115 millimeters, magnified 80 diameters. $a$, Meckel's cartilage; $b$, osseous formation; $c$, section of the dental artery; $d$, epithelial band (bourrelet); $E$, epithelial lamina; $F$, cord; $g$, enamelorgan. Meckel's cartilage at the right of the cut.

$H$ represents the incipient dental bulb. The drawing for this cut preserves the defects in the specimen from which it was taken. For example: the space between the enamelorgan and the follicular wall is caused by the shrinkage of the former, - a result of too long maceration of the parts. Similar defects will be found in several of the following cuts. 
'This little papilla, which represents the inciprent dental hulh, is empored at first only of mucleated embryolustic elements, and soon afterward of finsiform and stellate hodies. It will he noticed, also, that at this early stage of development a vascular loop enters its sulstance, similar to those found in the papillae of the skin; but we have not been able to discover in it anynerve-filues until it has attained a manl. millated form. 'The bull, retains this latter' form but a hrief perior, for it soon shows a tendency to take that of the finture tooth; thus, for the incisors and canines, it assumes a conical form; for the molars, in man and the carnivora, the primitive papilla is soon corered with secondary protuberances, equal in number to the cusps of the fiture crown: and in the compound molars of the herlir. ora and rodents throws out prolongations which represent also the futmre divisions of the crown. An analogons arangement is fomnd in the incisors (ie cormet) of the soliped. 
In all these circumstances the enamelorgan allows itself, as it were, to be moulded by the bulb, so as to exactly conform to whatever configuration the latter may as. sume.

Casper: The dentine-papilla determines, then, the form or contour of the crown of the finture tooth? I inferred from a remark you made (in regard to the supernmmerary teeth, I think,) that it was the enamel-organ that controls this matter; at least, that this was your opinion.

Teacher: Whatever views I may entertain as to the inflnence exerted by the enamel-organ have been mainly derived from these authors, though I have recently given this subject considerable thought. This is one of the points in dental physiology that has been almost entirely ignored by anthors who have written upon the development of the teeth. Drs. Legros and Magitot, however, express very decided views in regard to it, thongh they do not state the reasons upon which their opinion is founded. In a more recent work (Traité des Anomalies, etc., Paris, 1877,) Dr. Magitot, the surviving anthor of the present treatise, maintains, very 
positively, that the enamel-organ is endowed with this intluence. These are his words:

- It is explicitly admitted that the epithelial cord, or enamel-organ, dominates and determines the plare and the form of the tooth. The genesis and development of the dental bulb (dentinegerm), which makes its appearance subsequently to the cord, is absolntely dependent, as a physiological consequence, upon the presence and form of the enamel-organ itself. One will, nevertheless, be tempted to believe," he continues, "that the nature of the finture tooth is under the control of the dentine-papilla, a kind of organie mould upon which the calcific elements are grouped; but it must be remembered that the epithelial cord, which represents the future enamel-organ, always precedes the appearance of the dentinepapilla, which never originates till the cord has adranced a certain distance in its course. Accordingly, we believe that the epithelial cord decides not only the place of genesis, but the form and function of the corresponding tooth."

It will be seen from the above quotation that [). Magitot dissents from the general opinion in regard to the influence which these parts (namely, the enamel-organ and the dentine-germ) exercise upon each other.

As for myself, I had supposed that the enamel- 
organ was the more passive structure, and that its form, at least, was determined by the dentinepapilla. But, in considering this subject more carefully, and examining both sides of the question, I discover evidence which strongly confirms the theory of Dr. Magitot. My conclusions rest mainly upon a certain fact in the statement of Dursy, who, according to Waldeyer, says:

"The first germ of dentine appears in the dental saculus, as a dark, semi-lunar area at the bottom of the dental groove,- that is to say, of the enamel-germ, - cöetaneously and continuonsly with which it is developed along each half of the jaw. At certain points, corresponding to the position of the subsequent teeth, the young structure develops in the form of papillæ, projecting against the enamel-germs, while the remainder atrophies. The two horns of the semi-lunar mass (as seen in section) extend from the base of the dental papilla some distance upward, and embrace the dentine-germ and enamel-organ." .

The particular point in this statement of Dursy to which I allude, and to which I wish to call your special attention, is that referring to the semilunar area of tissue extending along each half of the jaw, and from which the dentine-germs are developed. If the anatomical description of Dursy 
is correct (and I am not aware that it is dispnted), a dentine-germ might be developed from any point of this semi-lunar area which should be retehed by the enamel-organ. No particular point is assigned to the development of any especiul dentine-germ: that is entirely aeciclental, and depends upon the course which the enamel-organ takes.

For example: If the epithelial cord of a enspid should deviate from its normal conrse, so as to come in contact with this dentinal sheet of tissue at a point between the bicuspids, the cuspid wonld be developed between those two teeth. In fact, whatever point in this tissue the enamelorgan of the cuspid should reach, the finture tootl would be a true enspid.

If this be admitted, the theory of Dr. Magitot must be true,- that the enamel-orgun determines the form and character of the future tooth.

If the fact that the teeth of certain tishes are wholly destitute of enamel, seems to militate against this theory, we have the statement from high authority that all teeth, whether clothed with enamel or not, are, in the formative stage, nniversally endowed with enamel-organs. May we not infer, then, that in such eases the rudi- 
100 THE ORIGIN AND FORMATION

mentary enamel-organ has performed its functions when it has incited the development of the dentine-germ, and determined its future form and character? *

As the dental bulb develops in height, it takes a slightly oblique direction in relation to the axis of the follicle, and at the same time undergoes a certain constriction at its base, thus forming a kind of neck at the line where (as has been already seen) the enamel-organ is reflected back upon itself. (Fig. 27.)

There is, however, one peculiarity in the structure of the bulb which we ought particularly to notice here, and that is the nature of the external surface of this organ.

If you examine the structure of a vertical section of the bulb, you will find that there exists at the periphery of this organ a thin, clear zone, which is easily distinguished from the subjacent tissue by its refiaction.

* [Extract from my report on Dental Physiology, read before the American Dental Association, August, 1878.-Tr.] 
'This zonc, to which several anatomist have assigned important functions, is only a thin stratum of amorphous naterial, which is wholly destitute of anatomical elements and of gramulations.

'This amorphous layer is not only more transparent, but somewhat denser, than the suljacent tissue of the bulh, so that sometimes it may be detached from the surfice of the latter. This fact has led many anatomists to suppose that the bulb was invested with a distinct membrane (the membana preformative of Raschkow). (Fig. 25, lower parallel line, A A, p. 89.)

We shall descrilue, in another work, the nature and functions of this structureless layer, but we will say this much in adrance, that it is in this tissue that the irory.cells [orlontoblasts] make their first appearance.

As soon as this little mass of new elements, which eonstitutes the dental bulb, has taken a hemisplieric form, two opanue processes, originating at its base, ascend di- 
102 THE. ORIGIN AND FORMATION

vergently upon its sides; these appear to emanate directly from the tissues of the bulb itself, and they represent the first trace of the wall [sac] of the future follicle. (Fig 22 I, p. 73.)

If, at this period, the constitution of these follicular processes be studied, we find them composed of exactly the same elements as the bulb from which they originate. As the bulb continues to develop, these processes also increase in length, and bend round toward each other, in such a way as to finally embrace in their double concavity not only the bulb itself but also the enamelorgan, which, as you already know, constantly crowns the latter. In this manner the follicular wall, which was at first only a little collar attached to the neck of the bulb, by its gradual upward growth finally em. braces and isolates both the enamel-organ and the dentinal bulb.

CASPER: We are told, at first, that the follicular wall originates from two processes, on 
opposite sides of the bulb; but now it is described as a little collar fixed to the neck of the bulb - apparently quite another thing.

Twanir: 'These authors, doubtless, at first deseribe the follicular wall as it appears in section. In reality it must be a circular process, which, in the diagrammatic figure, presents the appearance of two. Prof. Tomes says, in his Ilental Anatomy: "Irom the base of the dentine-bulb prolongations pass ontward and slightly upward, so that they in a measure embrace the firee edge of the enamel-organ; and, at a somewhat later period, they grow upward till they fairly embrace the whole enamel-organ."

Owen, in his Odontography, uses the following language: "By the development of three or four lanellar processes from the opposite sides * of the mouth of the follicle, and their mutual cohesion, the papilla is inclosed in a capsule."

Prof. Wedl, in his Pathology of the Teeth, says: "The dentinal germ proceeds from the Howr of the dental sac which inrests it and the enamel-organ."

Kölliker (fifth edition) says: "The dentinepapilla arises from the bottom of the dental sac."

Althongh the last two anthor's do not minutely 


\section{THE ORIGIN AND FORMATION}

describe the process of development, they evidently do not mean that the bulb arises from the "bottom" or "floor" of a formed sac, but upon the surface of a sheet of tissue which finally forms the sac. They agree with Tomes and the anthors of this work, excepting that the former histologists believe that the base of the dentinal bulb is inclosed within the walls of the sac; whereas the others believe the follicle, from its apex to the base of the bulb, to be invested by the sac.

At this period the follicular wall may be compared to a muff inflated in the middle, the lower opening of which corresponds to the base, or neck, of the bulb to which it is attached; while the opposite opening corresponds to the neck of the enamel-organ, that is to say, to the point where the latter is connected with the epithelial cord. Soon afterward the cord becomes severed at this point, by the resorption of its constituent elements; a cessation of continuity due, without doubt, to the compression or strangulation it undergoes from the encroaching 
walls, which now nuite at this point and completely inclose the tollicle. Thus the (2llmmel-()!gan loses the connection which it latd hitherto maintained with the epithelial lamina, and the dental follicle may be regranderl as definitely completed. (Fig. 2i.)

Fit. 27.

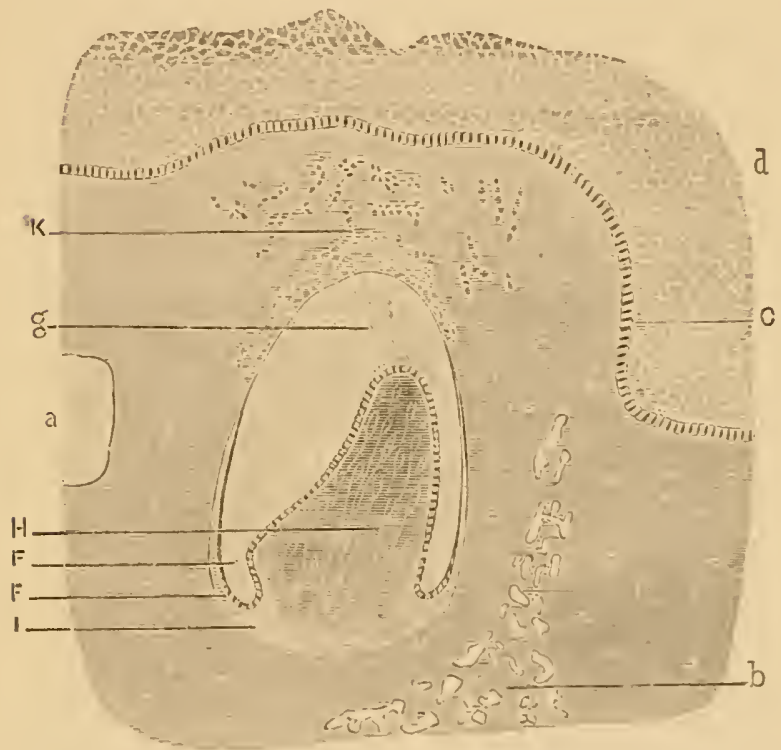

Fu. 27.-Section of the lower jaw of a bovine embryo, magnifier 80 diameters; showing the dental follicle, as completed, and the surrounding tissues.

", Meckel's cartilage; $b$, traces of ossification; $c$, lowest 8 
This wall [sac], composed primarily, as we have seen, of embryoplastic elements, gradually assumes the aspect of a distinct laminated membrane, which may be separated from the adjacent tissues, except at the base of the bulb, to which it remains fixed.

Kölliker, with most other authors, describes this wall as composed of two concentric laminæ; and yet admits, with Huxley, that the transparent stratum which clothes the bulb (membrana preformativa) reflects itself back on its internal face, and thus lines the whole inner surface of the follicular wall.

We will reserve, for a forthcoming work, the study of these different peculiarities of structure.

layer of the Malpighian stratum; $d$, oral epithelium; $F$, ameloblastic layer; lower $F$, external layer of the enamelorgan, - a continuation of the internal layer of ameloblasts; $g$, stellate recticulum of the enamel-organ; $H$, dental bulb; $I$, follicular wall (indistinct); $K$, buddings of the cord. The vascular appearance of the bulb does not appear in the original. 
Fiavk: With my ideas of the parts constituting the follicle, I fail to comprehend how the prefornative membrine can line the internal surface of the fullicular wall and also clothe the hulls.

Tescuse: Perhaps Krïliker's definition of the follicle, assisted by lïg. 25, may enable you to better understand this matter; and since it is brief, I will give you the benefit of it. In his 5th edition it reads as follows: "The dental sacs [follicles] are composed of three parts,-- the sac properly so-culled, the dentul ferm, and the enamel-organ. The proper dentul sac is an envelope consisting of two layers, - an external one composed of dense comnective tissne, and a softer internal one, of a gelatinous consistence, containing numerons connective-tisue corpuscles, and also some true fasciculi of connective tissue. This internal layer is limited on its inner surface, toward the enamel-organ, by a homogencons layer of extreme temity, the preformative membrane of the dental-germ" [bulb].

It the period of erolution to which we have arrived in om description, the tollicle is completed and closed. It now we examnine its general constitution. we shall find it 
10S THE ORIGIN AND FORMLATION

composed, proceeding from the outside inward -

1st. Of the follicular wall which clothes its entire surtace,-except the base of the bulb, which remains free. (Fig. 27, I.)

2d. Of the enamel-organ, subjacent to the follicular wall, to which it conforms in its whole extent, in such a way that while its extermal face corresponds to this wall, its lorrer, concare face is in immediate contact with the bulb.

3d. Lastly, of the bull itself, which occupies the lower and central portion of the follicular sac. (H.)

Except the three fundamental parts just named, no other substance finds place in the constitution of the follicle. The enamelorgan exactly fills all the space comprehended betreen the wall [sac] and the bulb, and terminates at the base of the lat. ter in a rounded margin, which forms the diriding line betreen the prismatic cells that clothe both its concare and convex 
surfices [see Fig. 25, A A]. 'This homml. ary, howerer, is not antificial. It results, on the one hand, firom anatomical differ(meces that these parts now present, and, on the other, from the physiological role which the cells of the concare face are called upon to perform; whereas the external liyer atrophies lapilly and disappears." 'This prismatic layer of the concave surtace (adimantine membrane), constituting, as we shall see, the stratum of enamel-cells [amel. oblasts], remins a long time in the compo. sition of the follicle: not only after the external layer has disalpleared, hut even atter. the atroply of the gelatinous part of the

* [ Waldeyer and Hertz believe this external layer of the enamel-organ. instead of being absorbed, to finally become the cuticula dentis, "Nasmyth's membrane." 'Tomes, Magitot and Wedl, however, attribute this membrane to another source, believing its origin identical to that of the cement; while Huxley maintains that the preformative membrane (sce upiper line, A A, Fig. 25), after the enamel is completed, constitutes this thin enamel covering. Thongh kïlliker does not assent to the latter theory, yet he believes this membrane to be a product of the enamel-organ. -Thi.] 
enamel-organ. Let us further add, that in the rodents (whose incisors, as we know, are of continuous growth) this layer of cells [ameloblasts] remains upon a portion of the anterior or convex face of these teeth during the entire life of the animal.

This constitution of the follicle, compre. hending, as it does, these three fundamental parts, seems to be characteristic of that of man, of the carnivora, and in general of all the mammals whose teeth are not supplied with coronal cement. But if the follicle of an embryonal soliped be examined, it will be noticed that for a long time before the formation of the first dentine-cap there exists between the follicular wall and the organs within it a new tissue, very distinct from the neighboring parts - in color, in consistence, and in composition. 'This is the organ upon which will subsequently depend the formation of the cement. We will omit the description of the cemental organ here, but will study it elsewhere in 
detail; all that we wish to estallish at present is its incontestable existence in the follicles of such teeth as are clothed with coronal cement.*

This fact is so decisive that hy the simple examination of a follicle we can determine, from the presence or the absence of this orgau, whether the future tooth will or will not be fumished with cononal cement.

The dental follicle, the component parts of which are all thus grouped and inclosed in one sac, has a general ovoid torm. Its

* This cemental-organ, which will always be found in the follicles of the moler's of herbivorous animals, and in those of the incisors aml molurs of solipeds, has been described for the first time in France, in a work by E. Magitot, entitled "Derelopement de la Structure lles Dents." (Thèse inaugurale, 1858 , p. 80 ). It was presented anew some years ater by Robin et Magitot. (Loc. Cit. 1861, p. 145 et suiv.) Since that time the existence of this organ appears not to have been recognized by any other anntomist. Indeed, in the last works published in Germany, by Kölliker. Waldeyer, Hertz. Kollmann and others, its existence has been formally denied. We are grently surprised to see so erident an anatomical fact thus contested; l, ut it will be easy for us to establish again the reality of this discovery, which we propose doing in our second memoir. 
size varies greatly in the different animal species, and according to the kind of teeth that are to be developed from it. When the follicle is completely formed, it remains inclosed within the embryonal tissues of the jaws, with which at first it is only feebly connected. 'Thus isolated in the depth of the jaws, having lost its communication with the mucous membrane [epithelium], by the rupture of the cord, it does not yet form any connection with the maxillary bone; for the formation of the alveolar partitions does not take place until a later period.

The net-work of ressels which ramify the follicular wall and dental bulb is furnished from different sources, and enters these tissues from the surrounding parts; while the enamel-organ, as we know, is nonvascular. The direction of the follicle, that is to say the great axis of the ovoid, which it represents, is quite variable. Though regularly vertical in man and the carnivora, 
it takes an obligue direction in the leeplise orous animals, and this is more particularly marked in the follicles of the incisol's. 'The. lister, in fiact, take an oblique and divergent comse, like the spokes of a wheel, which is moreorer in contormity with the inclination of the alveolar areh. (Fig. 2S).

Fig. 24.

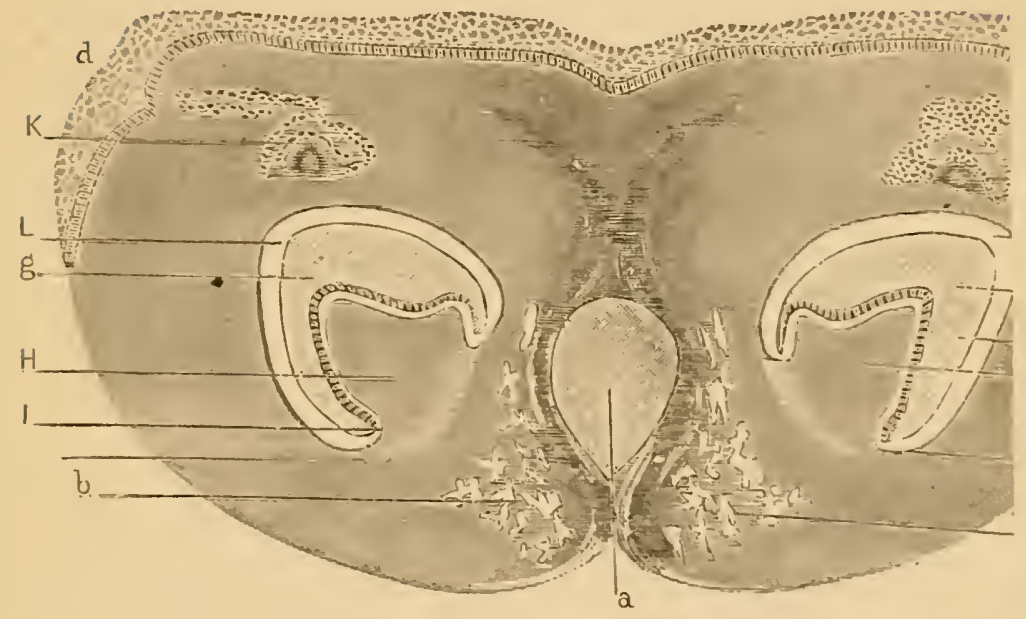

FIG. 28.- - Verticil section of anterior portion of the lower jaw of an equine embryo, magnified 80 diameters.

a, Meckel's cartilage; $b$, traces of ossification; $d$. oral epithelium; $/$, enamel-organ; $H$, dental bulb; $I$, layer of ameloblasts (internal epithelium); $\hbar$, permanent folliele; L, place assigned for the development of the cement. 
We may add, however, that the axis of the follicle is generally the same as that of the bulb, and that it strictly corre. sponds with that of the alveolar border, for each particular species. As to its position in the jaws, it differs in like manner according to the species. In man, the carnivora and the solipeds, it is situated quite near the mucous membrane [epidermis], and in these the epithelial cord is consequiently quite short; but it is located more deeply. in the bovine and ovine herbivora (cattle and sheep), and the cord consequently acquires a proportionate length. 


\section{CHAPTER IV.}

PHENOMENA THAT FOLLOW THE FORMATION OF THE FOLLICLE, AND TIE RUPTULE OF TIE EPITHELIAL CORD.

A soon as the sac is closed, and the follicle the epithelial cold, valious phenomena are produced in the embryonal tissues that surround this olgan, in the legrion hetween the summit or apex of the follicle and the epi-

- thelial layer of the grmm. 'These phenomena are principally located in the epithelial lamina and in the cord itself.

In fact, as soon as the epithelial lamina loses its connection with the follicle, by the rupture of the cord, the epithelial cells composing it become greatly increased in number at the severed point. 'Tlis multiplication of cell-elenents results in the formation of irregular huddings, which 
wander in different directions into the deeper portions of the embryonal tissue. These buddings vary greatly in for'm; sometimes they are simple cylinders, retaining their connection with the primitive lamina by pedicles of various lengths, and sometimes this slight connective is absorbed, thus isolating an epithelial mass. (Fig. 19, F, p. 67.)

These masses are formed wholly of large polygonous cells, similar to those found in the center of the epithelial lamina; but they are never, like the latter, surrounded by a layer of prismatic cells. Very frequently, however, groups of these elements take the globnlar form, and are, in every respect, similar to those which are sometimes discovered within the epithelial lamina itself. (Fig. 29, F.) These different dispositions account for the presence of epithelial masses of such raried form; which, until now, were unexplained, and' which are found in almost all the sections of the jaws made at this epoch of evolution. 


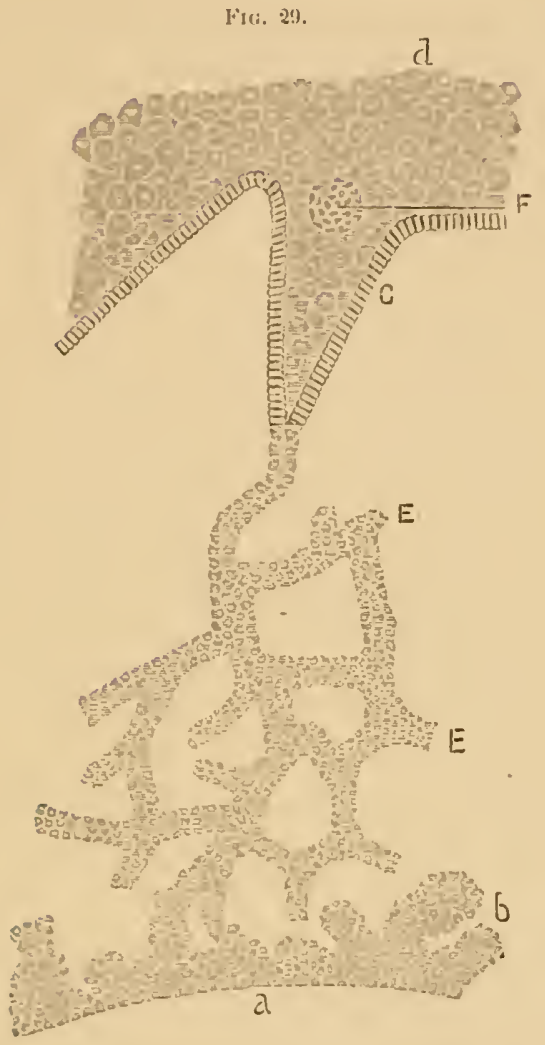

Fig. 29.-This is a section taken from an embryonal calf. (Magnified 260 diameters.) Like fig. 19, it embraces the region external to the follicle (a), which latter is not shown on the cut; $b$, epithelial buddings upon the follicular wall: $E E$, buddings of the epithelial cord; $F$, globular epithelial mass in the lamina; d, oral epithelium (epiclermis); $c$, epithelial lamina "still intact." 
These phenomena of buddings cease at a certain period, which always seems to be anterior to the time at which the dentine makes its appearance in the follicle; and then all the epithelial fragments, and the lamina itself, undergo gradual absorption, and entirely disappear before the development of the tooth is perfected.

Coincidently with the phenomeua thus effected at the expense of the epithelial lamina, a series of modifications precisely analogous transpires also in the severed cord itself. From the remnants of this cord, buddings, or processes, issue, which, at times, are rel'y numerous; as we have witnessed, for example, in certain preparations taken from the jaws of bovine embryos. These phenomena continue for a considerable length of time, since they can be observer up to a period even verging on the eruptive stage. The general form of these buddings may vary; sometimes they present somewhat the appearance of a bouquet, 
(the fout eorespending to the smmmit of the follicle, which symeals, opens and contimes to expand till it reaches the vicinity of the epidemis (Fig. $27, \mathrm{~K}$ ); at other times they form, ly a multitule of reciprecal mastomoses, a perfect net-work (1)ig. 29. E E), in the midst of which are still found somle isolated malsoes.

But these ditterently grouped an anastomosing budlings do not all follow the di. rection of the lamina, nor of the cord; in fact their general tendency is evidently toward the surface of the mucous membritle.

The déloris of the cord are invariably comprosed of small polyherlal cells lying in juxtip) sition to each other, and exilctly+ similar to thome of the cord itselt; hut the cells componing these therix, like those of the remains of the lamina, ale nerer invested with a liyel of prismatic cells:

'The buclelings of the cond atre also of varlialle size: some are extremely slemelel, 
and composed of a single string of cells; others assume a strumous or swollen form, and contain several superimposed layers of these elements; but the large cells and the globular masses - the presence of which we have recognized in the débris of the lamina - are never found here.

The remains of the cord, like those of the epithelial lamina, after undergoing these multiplications, become gradually absorbed, and disappear, as was previously stated, at or about the period of eruption.

While these phenomena of buddings are taking place, at the expense of the débris of the cord, it will be noticed that a similar process is going on at the exterior surface of the follicular wall. These two series of phenomena, as well as those that take place in the lamina, are simultaneons."

In fact, if a vertical section be made of the region comprised between the summit

* All this array of facts has been presented for the first time in France, by Robin and Magitot. (Loc. cit., 1860, p. 74.$)$ 
of a follicle and the external surfice of the epideruis, shortly atter the rupture of the cord has taken place, it will be seen that the remmants of this and even extend to and mingle with sone of the proliferations which are adherent to the wall [rac]. These have the most raried forms; most frequently. they are chub-shaped expansions, or cylinders of different lengths, terminating in a romeded extrenity: and sometimes provided with a kind of pelicle. 'They cover' nearly the whole surface of that hemisphere of the follicle which is presented toward the epidermis. These huddings, however, are most abmond at the apex of the follicle [the point where the cord was at. tached], and they gradually diminish as they descend upon its sides. They anastomose tramsiersely both with each other and with those that are attached to the cord; and in such a way that by simply eximining the surface of the follicke, withont making a rertical seetion, we pereedre a kind 
of plexus with rery irregular meshes, superposed upon the follicular wall. (Fig. 29, b.)

The anatomic structure of these bourgeons [or prolongations] on the surface of the follicle differs in no respect from those which we have indicated in the proliferations of the cord, being composed of the same small polyhedral cells minus the enveloping prismatic layer. This identity of structure results from the fact that these epithelial masses are derived from the remains of that portion of the cord which is in the nearest proximity to the follicle, and which by propagating themselves thus finally constitute this reticular covering of the follicle.

All these phenomena of epithelial proliferations relate, therefore, to one and the same process. Commencing with the lamina, these buddings extend to the $\operatorname{cor}^{2} d$, and finally even to the surface of the follicular wall; they are connected with each other, possess the same anatomical constituents, and all finally disappear by absorption [un- 
less it be some maseres that may hecome the enamel-orgams of supermmmelany teeth. (see 1. 66.) - $\mathrm{Tk}$.

We have indicated in the foregroing the period at which the phenomena of hulding conmence, namely, when the epithelial cord has finished its conrse, having conducted the primitive enamel-organ to that point where its subsequent erolution will he effected, and soon after the formation of the seconclary follicle; [in other worls, immediately after the rupture of the cold of the primitive follicle]. The time of their dis. appearance varier in the different species of animals. In the human embryo the remains of the cord of the primitive follicles maty be found even atter the formation of the follicles of the premanent teeth, and it is prob. ably during the process of eruption that these budlings becone atroplited: in the amine embryo the fircts ane nearly the same; in the bovine and orine emhlyos (calt' and lamuh), it has seemed to us that these pro- 
liferations disappear at a correspondingly earlier stage; and we think it safe to say that, as a general rule, the complete absorption occurs toward the period of eruption.

The physiological signification of these phenomena appears to us difficult to deter. mine. We have no personal opinion to ad. vance in this regard; nevertheless we will say that, considering their mode of evolution and their structure, no glandular character whatever can be attributed to them, as some have supposed.*

* Serres, as is known, described what he supposed to be special glands, tartaric glands, in the mucous membrane; and his views were supported by Kölliker, Todd and Bowman, and others. The anatomical nature of these epithelial masses, and the fact that the production of tartar is connected with quite different phenomena, leaves no foundation for this hypothesis.

[I have not the works of Todd and Bowman at hand, but think Legros and Magitot must be mistaken in regard to the opinion of these authors upon this subject. As to the views of Kölliker, in the fourth edition of his Microscopical Anatomy, speaking of the "gum in the foetus," he says: "The bodies of the size of a millet-seed, contained in it, described by Serres, the so-called glandulce tartarica, which are supposed to secrete the tartar of the teeth, are 
While: the molifications just deseribed are being eflected at the expense of the epithelial delurix of the corel and the lamina, the embryonic tistere in which the follicles are immersed also changes its natme, and some laninated elements appear therein, forming a loose and transpalent net-work.

The osseons tissue of the jaw (no trace of which is seen at the time of the origin of the prinitive cord) makes its first alppeatrance neal the hase of the follicles, where it soon forms a horizontal layer, separating the groove of the follicles from the canal reserved for the ressels and nerves. Lateral processes then arise from this layer or floor, and form the groove in

aggregations of epithelium, and probably pathological." In his fith, in place of the words " and probably pathological." the followng are substituted: "which, according to my recent observations, are the remains of the embryonal grem of the enamel-organ" [i.e.. of the epithelial lumina]. The views of Kïlliker, and Legros and Magitot are then precisely the same on this point, so far as they are expressed in these works, the only difference being in the form of expression. - Tr.] 
which the follicles lie for some time without being separated by transverse partitions. But later, after the development of the crowns of the teeth has commenced, bony processes are thrown across this groove, forming cells for the lodgment of each follicle, with an opening toward the epithelial surface.

A rich rascular network of tissue 'surrounds the follicle, and ramifies the substance of the walls even to the surface of the enamel-organ, but does not penetrate it.

The vessels of the bulb are entirely distinct, forming no anastomosing connection with the preceding plexus. We shall, however, have occasion to refer to these particulars hereafter, in treating of the morphology and structure of the follicle. 


\section{CHAPTER V.}

TIIE PLACE, AND MOUE OF ORIGIX, OF THE FOLLICLES OF TIE PEIMANEXT TEETI.

THE arigin of the follicles of the perI mament teeth is a problem that has received particular attention trom the more recent anthors who have studied the evolu. tion of the teeth. It is one which we also have examined with the greatest care and patience; and we beliere we hare succeented in solving it correctly.

Since the publication of the works of Goodsir-in which that author held that the follicles of the permanent tecth arise from a fold of the sac of the primitive follicle - most anatomists have adopted his theory without examination or verification. This doctrine is no nore in confonmity with the fircts than is the theory that the 
sacs of the temporary teeth are formed by an inversion of the mucous membrane. We have already given our views in regard to this hypothesis, and we will refer to it again at the close of this work. The theory of Goodsir will be found as erroneous in regard to the permanent as it is to the temporary teeth.

We ought to mention, however, that Kölliker and Waldeyer have come near the truth in indicating and illustrating certain prolongations of the primitive cord, which are destined to become the secondary cord. But in the most recent work published in Germany, that of Kollmann, the preceding interpretation is not adopted.* According to the riews of this anatomist, the cord of the permanent teeth arises fiom the remnants of the primitive cord, which, after its rupture, produces those several buddings or epithelial masses which we have already described. He believes that

* Kollmann, loc. cit., p. 162, ete. 
the enamelorean of the permanent tooth originates from a mas of those epithelial fiagments. In a like mamer he accomnts for the production of the supernmmerary teeth." This new theory is equally erroneous: and if this German author has heen deceiver he certain natural appearances, which might farol his oppinion, it is because he las neglected to follow out strictly, in their sucessive physiological phases, the phenomena of this special evolution.

Furthermore, the origin of those permanent follicles that have been preeeded by corresponding temporary ones, is altogether diflerent from that of those which had no such predecessors; so that while all of the trenty follicles of the jermanent teeth that sleceed the twenty temporaly ones have a like origin, the twelve other follicles (the molars of the adult) have a diflerent mode of genesis. [By this these authors mean, as will he seen hereatter, that all the enamel-

* [See note, f'p. 65-fi of this work.-T'rr.] 
organs of the permanent teeth except those of the first molars, originate from the epithelial cords of other follicles, and not directly from the epithelial lamina itself.Tr.]

The facts we are about to adrance have been gathered from the examination of a large number of mammalian embryos, comprising a series of successive phases of development. In studying microscopical sections taken from the jaws of human embryos measuring trenty centimetres from crown to heel, a bourgeon will be found at the point where the primitive cord merges into the enamel-organ of the temporary tooth. The general form of this bourgeon is cylindrical, terminating in a somewhat enlarged extremity, which gives it a clubbed or gourdlike shape at this stage of evolution (Fig. $30, \mathrm{~K}$ ), and may be seen quite distinctly with a low magnifying power of 100 to 200 diameters. [Fig. 22, K, represents this bourgeon at an earlier period]. It takes a general 
vertical direction, and patses between the osseous alveolatr wall and the primitive fol-

Fig, 30.

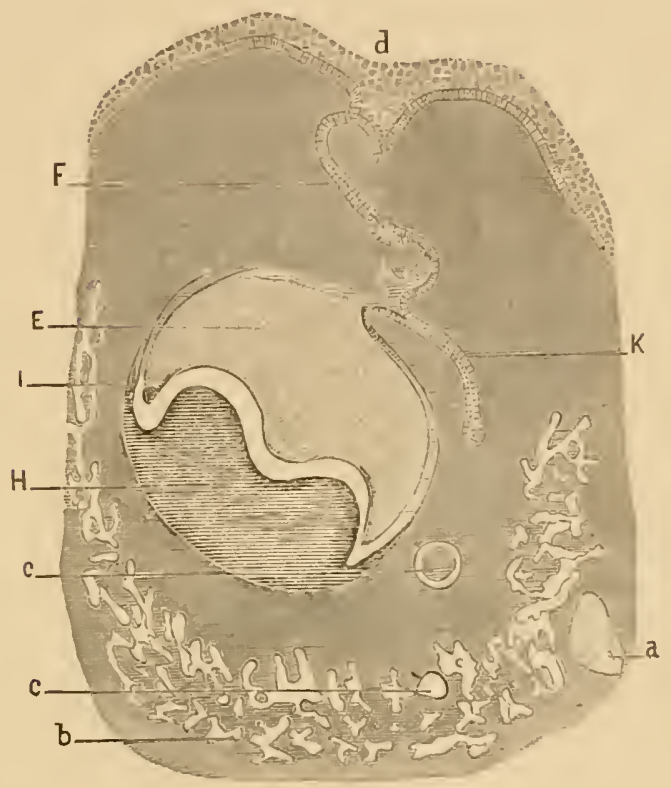

Fir. 30.-Section of the lower jaw of a human embryo. totil length 20 centimeters, or about $S$ inches; taken from the region of the follicle of the temporary molar (magnified 80 diameters).

$k$, cord of the permanent follicle, "emanating " from that of the temporary molar; $E$, entmel-organ: $F$, cord of the temporaty follicle; $I$, dentine-bulb; $I$, follicular wall; u. Meckel's cartilage; $c$ (upper), section of the dental artery; $c$ (lower), that of the dental nerve; $d$, epithelial cells. 
licle, along the internal or lingual face of the latter. The elements of which it is composed are the same as those of the primitive cord, of which it is in reality only a diverticulum or out-growth; that is, of polygonous cells covered with a single layer of prismatic ones.

This bourgeon or bud represents the beginning of the permanent tooth; and after it has become sufficiently developed, one can easily follow the subsequent phenomena of which it is the seat. It sinks to the bottom of the osseous dental groove, where it soon loses its connection with the primitive follicle, though still retaining its communication with the lamina; while the primitive follicle, by the severance of its cord (which takes place just below the point where the secondary cord branches off), becomes isolated from its epithelial comnection and continues its individual evolution. (Fig. 31.)

It was, doubtless, by examining the jaws at the stage of development just referred to, 
without takine into accomut the earlier and later phases, that led to the helief that the cord of the permanent teeth emamated from

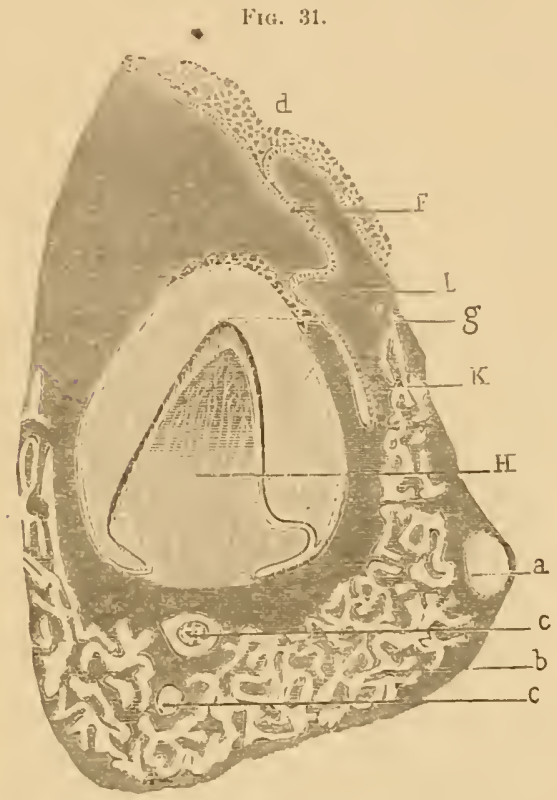

Fic, 31,-Section of the lower jaw of a liuman foetus, 23 centimeters in length [or $9^{1} \frac{1}{4}$ inches; corresponding to alout the 18 th week].

$K$, cord or bourgeon of the permanent follicle; $L$, point where its separation from the primitive cord is being effected ; $y$, enamel-organ; $I I$, bulb; $c$, section of the dental artery; b, traces of ossification: c, (lower) nerve; a, Meckel's. cartilage. 


\section{THE ORIGIN AND FORMATION}

the débris of the primitive cord, or directly from the epithelial lamina. (Fig. 32, K.)

The descent of the secondary bourgeon.

Fig. 32.

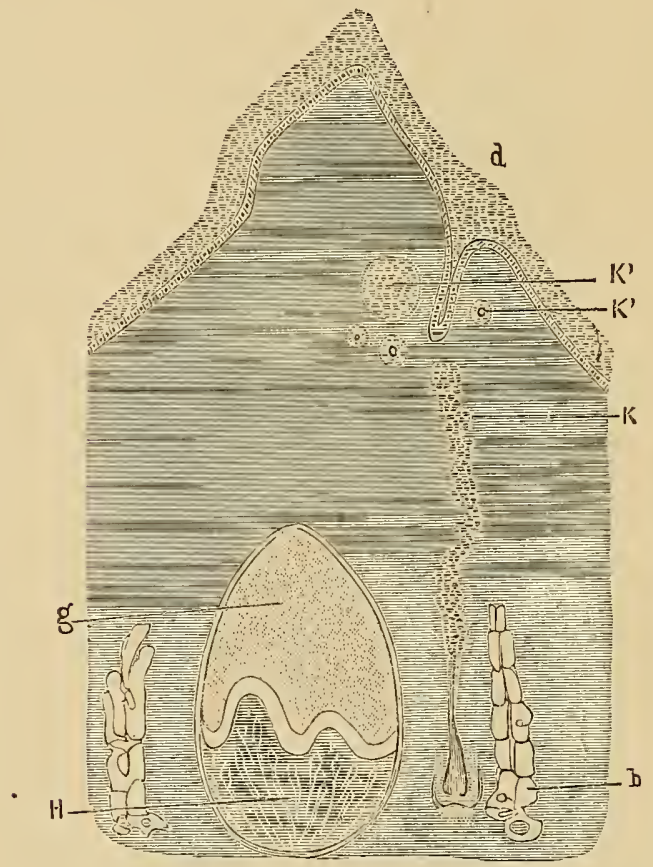

Fic. 32.-Vertical cut of the lower jaw of a human fotus, measuring 47 centimeters [ $181 / 2$ inches, and corresponding to about the 39th week of gestation]. This figure represents a section passing through the follicle of a bicuspid. $K^{\prime} \boldsymbol{K}^{\prime}$, epiclermal masses; $K$, débris of the secondary cord; $g$, enamel-organ; $H$, bulb; $b$, bone of the jaw; $d$, epidermis. 
into the dental groove is som followed ly the entire series of phenomenal which are common to every follicular evolution, . . Land which are precisely the sime as those aheary described for the primitive homsgeons.] (lig. 32, K.)

While these phases of development ane being accomplished, certain modifications oceur in the parts which surromel the prim. itive follicle. The stmmp of the ruptured cord, which remains attached to the prin. itive follicle, hecones the source of those fiagmentary guwtho and huddings which hare heen described at considerable Jength in a jreceding faragrall. These phenomena commence in the human embryo when it has attained ahout twenty-three centimeters [or nine and one-fumth inches] in lengeth, allunt the fomth month. These phemomena, which always conmence trom the noment the cord is serered, seem to areme in the embryos of other mammils a little eallier, relatively, in the period of gexta- 


\section{THE ORIGIN AND FORMATION}

tion. This is the case in equine and bovine embryos. Besides, in the lower animals the secondary bourgeon emanates from the primitive cord at a point a little farther from the primitive follicle than in the human species. This is also the case in the ovine embryo.

CAsper: I have just been reading a treatise styled the Anatomical, Physiological and Microscopical Researches on the Teeth, by Dr. J. E. Ondet, a French writer, whose opinion, it seems to me, is entitled to considerable respect. He most emphatically denies that any of the permanent follicles are derived either from the cords or from follicles of the temporary teeth; on the contrary, he claims that they emanate, directly and independently, from the "mucous membrane." It seems very strange that there should be such wide differences of opinion in regard to a simple anatomical fact.

Teacher: Nearly all of the most eminent histologists of the present day,-Tomes, Kölliker, Waldeyer, Frey, Owen, Wedl, and I know not how many others, entertain essentially the same views in regard to this phenomenon as are here 
set forth by 1)rs. Lexpros and Magitot. There ale. howerer, a few distinguished writers, foremost among whom is the anthor you nimed, who believe that all the permanent teeth originate independently of the temporary set. Them, * agalin, we have one histologist, onr neighbor, Dr. fr. V. Black, of Illinois, whose extensive observations in this direction have convinced him that, althongh the epithelial cords of the twenty anterior permanent teeth generally arise frour those of the temporary follicles, yet that they do sometines emanate directly from the epithelial lamina. It would appear from fig. 30. and also tig. 31, in the Summary of Illustrutions (drawings of which were kindly turnished me by this gentleman), that his views are demonstrated beyond question. The histological specinens from which these drawings were taken have been examined by myself and others: and, saving a few minor and unimportant details, they are finthfinlly represented in these cuts. I lave the assurance of Dr. Black that these were taken by limself from the incisive region of different human embryos. In these figures the epithelial corts of the permanent follicles appear to emanate directly 10 
from the lamina; in figs. 32 and 35 , from the epithelial cord ; and in figs. 26, 27 and 28, from the primary follicle itself, rather than from its cord. (For these five figures, also, see Summary.) If all these figures are true representations of the parts themselves, the secondary cord may. emanate directly from either the lamina, the cord, or the follicle itself:

Now, one word as to the place of origin of the third permanent molar. I am not prepared with any positive proof that this does not emanate from the source attributed to it by the anthors of this work, and also by the several eminent authors first named, except Wedl. In closing these remarks I will only say that when I consider the distance and the direction that this cord must pursue,- starting from the point on the lamina from which the first molar arises, and extending in a backward, horizontal line to the spot where it eventually is dereloped; and, when I take into account the period of time that this cord must retain its normal attachment to this remote point in the epithelial lamina before the development of this follicle commences,-which cannot be less than three and one-half years; and when I add to 
these tatets the great morphological changes that oceur in the neighboring and rapidly-dereloping parts during this long interval of time; - in view, I say, of all these nnfirorable circumstances, I an not prepared to accept the theory advanced by these celebrated anatomists in regard to the origin of the wisdom tectl, without more positive evidence to sustain it. My own observations on this subject liave not been conducted with sufficient scientific acenracy to justify me in placing my conclusions (or convictions) on record liere; but I hardly need say that these points in embryonal histology require much careful revision.

Some differences are observed also as regards the direction of this secondary cord in the different species. Thus, while in the human embryo we have noticed that it takes a vertical direction, in those of the herbivora it follows a rery oblique course; so that from the external side (not far from its comnection with the epithelial lamina), passing above the tem. porary follicle, it pursues a curvilinear route 
140 THE ORIGIN AND FORMATION

to the internal or lingual face of that follicle. This arrangement of the parts may be seen clearly defined in sections taken from the incisive region of hovine, ovine and equine embryos.

The point upon the primitive cord from which this secondary bourgeon emanates, as also the direction it takes, are not necessarily governed by the length of the secondary cord; for in the human embryo, although its direction is rertical, it is longer than in the equine, in which it takes a circuitous course. As a general rule, its length is governed by the height of the alveolar border and the direction of the primitive follicle. In man and the car. nivora this height is relatively more considerable; and besides, the great obliquity that the primitive follicles of the incisors of the herbivora assume, allows the secondary bourgeon to cross directly over the maxilla, and to place itself, after a very short passage, on the internal side of the primitive follicle, where its evolution is completed. 
The enelel of the secomelany folliele, in its descent inte the jalls, alwals assmues a spiral form, and thus perfectly resembles the aluet of the surlorific erland in the ppidermis. 'This special disposition is so marked a chanacteristic in the secondaly rord, that it may he reatily distinguished firom the temporam corel; for thomgh the latter describes some simnosities in its (onurse, it is nerele so distinctly spiral as the formel. The necessity for this encalter syrimatity in the cord of the premalnent follicle may be explained by the fact that it must trarelse the more developed tiscue of the jaw to a gleatel distance in attending this follicle in its passige to il point heneath that of the temporary tontli: [and also to allow the latpidly dereloping palle to incorease the distance heetween the follicle and the ppithelial lanina, without straining the colet or disturhinge the parts

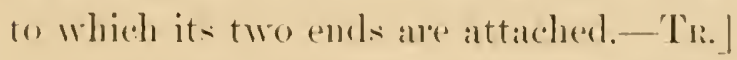
'Tlue spiral charactere of the secomblary 
cord is especially obvious near its point of origin, and in the first half of its course; but toward its terminal extremity it diminishes, and finally disappears entirely, giving place to a rounded club-shaped enlargement exactly like that which we have described at the extremity of the primitive cord. 'This enlargenent or expansion represents the enamel-organ of the permanent tooth.

When the series of evolutionary phenomena has brought the new follicle to the period in which, in the human embryo, for example, the bulb becomes unicuspid for the canines and incisors and multicuspid for the molars, the epithelial cord, which has already been sometime severed from the primitive follicle, becomes in its turn ruptured. From this period the secondary follicle, as well as the primitive, is found isolated from all connection with the epithelial lamina during the subsequent phases of its evolution.

This rupture is soon followed by new 
subdivisions in the sulstance of the cord itself, which seems to separate into fiagments of varions sizes. These firgments lenerthen and hod in ditterent directions to such a reglee that these epithelial processes an'e mingled and ronfonnded with those of the primitive corel, anastomosing with them, to form in this resion a solt of plexus, sometimes quite close, and which extruds evento the buddings that cover the follicular wall. Finally all these epithelial masses, after having thus prolitelated and "vegretated," atrophly and disappear.

such is the mode of genesis of the fol. licles of those permanent teeth which are preceded lig conlesponding tempoling ones. 'Twenty of the teesth thus oricinate. But we find that the first tereth that appear behind the deciduous set alle produced by an entirely different mode of genesis. The first permanent melure, the follicle of which becomes considerahly deveropere in fiutal life, is clerived from an epithelial cord which 
originates directly from the epithetial lamina. This cord penetrates the foetal tissue in a region where no follicle has preceded it. (Sum. of Illus., Fig. 39.)

The origin of the second molar is similar to that of the first twenty permanent teeth, the follicle being produced from a diverticulum or outgrowth of the cord of the first molar. In this respect the second molar sustains the same relation to the first, that the permanent tooth does to the corresponding deciduous one. But they differ in the direction taken by the epithelial cords; for, while those derived from the cord of the temporary follicle pass over: the lingual face of the latter to a point beneath, them, that of the second molar takes a horizontal course for some distance, and then by an inflection takes its position at the posterior side of the follicle of the first molar, where it is developed in a line with those anterior to it. (Sum. of Illus., Fig. 35.) As regards the last molar, or wisdom tooth, its origin is 
effected in a manner sinnilar to that which we have just described ; that is, the eprithelial cord that produces its enamel-organ is an emanation firm the cord of the seeond molat. We must anknowledge, however, that in determining the origin of this tooth we have encombered many difticulties, owing to its position and to the alteration in the tissues, caused ly the many reactions to which the jaws, atter they have acruired considerable size and hardness, must necessilrily be smbmitted. And yet, we have, in sereral canes, been enabled to determine, with ahmost positive certainty, that the "orl of the wisdom tooth originates in the mamner we have ahraly indicated. From these olservations we percesive that, while the first molar originater, as we have seen, from the epithelial lamina itself, it hecomes, through the medium of its cord, the somere firom which the follicles of the streceeding molars alle derived.

Howerel this maly be, with these recept. 
tions in the mode of genesis of the follicles, all the erolutionary phenomena are identical, to whicherer dentition they may belong; nerertheless the order in which their evolution is accomplished and the duration. of their physiological phenomena differ. For, while the follicles of the first dentition are dereloper during the period embraced between the latter part of the third month of gestation and the beginning of the fourth year (within forty-two monthi), most of the follicles of the second dentition require a much longer time tor their evolution. Fol example, though the follicle of the first molar makes its appearance in the fifteenth reek of embryonal life (and only a few day's aftel the most of those of the first dentition), yet it does not complete it: evolution until ahout the sixth year. We see, therefore, that though the evolutionary phenomena of the follicles are identical in other respects, they cover periods that vary according to the nature and the temporary or permanent character of the future teeth. 


\section{CHAPTER VI.}

CHRONOLOGY OF THE DENTAL FOLLICLE, OR THE PERIODS IN WHICH ITS SEVERAL COMPONENT PARTS APPEAR.

IN pursuing our researches on the mode mammals, we have constantly kept in riew one important question, namely, the determination of the periods at which the sereral organs that enter into its constitution make their appearance. This study has necessitated the careful examination of a large number of embryos, both human and of the principal domestic mammals. Another fiact to be ascertained was, the exact age of the suhjects upon which our observations were made. This, in the ahsence of positive evilence as to the period of conception, must, in most cases, be determined by measurement. Now, while the relation he- 
tween the size and the age of the human embryo has been determined with great accuracy, by the aid of statistics collected from the reports of various authors; yet, up to the present time no sufficiently accurate data of this nature have been given concerning the other species of mammals in their successive stages of embryonal life. In the human species, (the study of which affords us more interest than that of any other, and may he more usefully applied,) we have made numerons observations upon a series of embryos measuring from 3 to 37 centimetres [ $1 \frac{1}{4}$ to 15 inches] in length, i.e. from the serenth to the twenty-eighth week of intra-uterine life. From these we have been enabled to fix all the periods of the evolution of the follicles of the first, and some of those of the second, dentition. We have established the other phases of the second dentition by the study of subjects in the later stages of foetal life, and at different periods after birth. 
The smallest of these ambryos, that of 3 rentimeters | $1 \frac{1}{4}$ inches], (serenth week,) from which we have made tertical seretions throngh the entire fince (Fig. 7 ), has enabled us to detemine that at this period no point of ossification is yet found upon any jart of the cranimm or of the fince; the lower jaw alone presents some rudinentary osseous arehes in the vicinity of Meckel's cartilage. This filct is in conformity with the olservations publisherl in a memoir on Meckel's cattilage, in 1802, by Drs. Rolin and Magitot.

At this period in embryonal lite the jaws offer nothing for our consisleration, relating to the erolution of the follicles, except the apithetial band, which is found to he alike in both jaws (Fig. 7), and which we have allearly described. The folliele has not as yet appeared in these rudimentary parts. nor even the first trace of the epithelial lamina.

The second embiryo submitted to ome 
observation was $5 \frac{1}{2}$ centimetres * [2 $\frac{1}{4}$ inches] in length, say of two months. From this we ascertain that the formation of the dental groove commences at this period of development, and that the epithelial cords representing the enamel-organs are very clearly defined; the dental bulb has already made its appearance as an opaque point in the region previously designated as its place of origin. This period of development, compared with the preceding, has enabled us to fix the time of the appearance of the epithelial lamina between the seventh and eighth weeks of embryonal life; and the genesis of the enamel-organ from the epithelial cord, about the eighth week.

Moreover, from these examinations we have been able to determine the important fact that development progresses at the same rate in both jaws, as well as in all the follicles of the first dentition, whether they be of the incisors, the canines or the

* $\left[\right.$ A centimetre $=0.39371$, or say $\frac{2}{5}$ of an inch; a millimetre is $\frac{1}{10}$ of this, or $\frac{1}{25}$ of an inch. -Tr. 
molars. Upon a third emliryo, which moasured $7 \frac{1}{2}$ exntimetres $[3$ inches $]$ colresponding to the eleventh week, we discovered that the stages of development for eareh of the follicles of the first dentition were identical, and that the bulh, had become uni-cusprid for the incisors and canines, and multi-cuspid for the molins. 'The walls which had already risen fiom the base of the bulh were not yet united at the summit of the follicle, and the epithelial cord was still entire. The bulb now consists of amorphous matter interspersed with nuclei, though its external surface presents a memhluburs appealinee. The enamel-organ is distinctly stellated, and the colls that constitute the external epithelimm are becoming smaller as compared with those of the internal epithelium [the ameloblasts]. No trace of the secondary cord is yet seen.

From our ofservations on a fourth embryo, of 11 centimetres [ $4 \frac{1}{3}$ inches], say 
of twelve weeks, we ascertained that at this period the follicular walls are not closed, and that no trace of the dentinecap is yet visible. The next embryo examined (measuring 15 centimetres $[6$. inches], indicating thirteen weeks, showed no perceptible difference in development as compared with the former.

In an embryo of 20 centimetres [8. inches] (say at the commencement of the fourth month) we collected some valuable facts in regard to certain ulterior phases of evolution.

At this epoch the primitive follicular. cord has not yet become serered, nor the follicle closed. A little cap of dentine is seen very clearly outlined in some, thongh. not in all, of the follicles of the temporary dentition. It is, in fact, at the exact period when a slight trace of ivory is formed that we discovered the first chronological difference in the development of the follicles of the temporary teeth. For while the inci- 
sors and the eanines are now provided with a (alp) of embryonal dentine, it does not ap)pear mon the molars mitil about a week later: The hulh [dentine-germ] has now the exact form of the erown of the finture tooth; its hase has ahrady hecone cons. stricted and is embraced hy the matreins of the enamelorgan, which is alrealy completely constituted, with its internal layer of cells [amelohlasts], and the stratum intermedium well defined.

It is also at this period of derelopment that we first seee, emanating fiom the primi. tive cord, those huddings which are destined to form the secondary cords, or the enamel-organs of the permanent teeth. All these bourgeons (or huds) representing the commencement of the permanent follicles, are, in both jaws, at the same stage of erolution [in other words these enamel-buds start simultaneonsly].

From an emhryo of nearly the sime dimensions as the preceding (23! centimetres 
154 THE ORIGIN AND FORMATION

[91 inches] in length, and corresponding to the eighteenth or nimeteenth week), we have fixed the epoch at which the separation of the secondary cord from that of the primitive follicle takes place. The latter now becomes isolated from the epithelial lamina and continues its evolution without any further comnection with this tissue. (Fig. 31, p. 133.) The permanent follicle, however, still remains attached to the cord, and, by the latter, to the epithelium. We direct attention to these facts, because in neglecting to take account of the successive phases of evolution one might he led to believe that the follicles of the permanent teeth originate directly from the epithelial lamina, and not from the cords of the temporary teeth. This last mode of genesis is, on the contrary, definite and invariable for all the follicles of the permanent teeth which have been preceded by corresponding temporary teeth, that is to say, for twenty of the teeth of the second dentition; viz., the eight in- 
risols, the fome combines and the eight pore molals [liderspids]. It will he seroll that the other follieles of the permanent teeth hase a diflerent enighin. The seretions taken fiom the jaws of the amberyo (:en contimetres in length) have enabled us to detere mine positively the period and the mode of genesis of the cond of the first permanent molar, which is not, as is known, plecereleel by a corresponding temporary touth. 'This genesis takes place at the extremity of the epithelial laminas : and since, in the embloryo above named, the epithelial cord had al. ready acpuired comsiderable length, we may reasonaluly conchule that its dereloj). ment commenced about the seventeenth week of gestation. (Fig. 39, Smmmmar!\%)

At this epoch, when the sepaldition of the temporang follicles from the cond of the colresponding permanent ones takes plater, there alpears alse the first trales of these phenomenta of hudlings and of divers proliferations of the deheris of this printive 
cord and of the epithelial masses on the walls, - particularities which were first described in France. ${ }^{*}$ By the examination of other human embryos ranging from 27 to 37 centimetres $\left[10 \frac{3}{4}\right.$ to 15 inches], and upward, we have been able to fix the sulsequent phases of evolution, not only of the temporary follicles, but also those of the permanent teeth. These successive studies have thus brought us up to, and even beyond, the period of birth. In this manner we have been enabled to establish two points which remained to be elucidated in this order of researches, namely: the mode and epoch of the evolution of the follicles of the second and third permanent molars. The results to which we have arrived in regard to these, are the following: On examining sections taken from the jaws of subjects two or three months after birth, we discover in the region occupied by the follicle of the first permanent molar, a pro* See Robin et Magitot, loc. cit., p. 75. 
cess or prolongation, cylindrical in form, manating fiom the epithelial (a)d of the latter tollicle, and which takes a horizontal and harekward divection, temmating in a bulhous extremity. This prolongation is the commencement of the follicle of the secomd permanent molar. Thus we fix the date of the origin of this follicle at the third month after hirth. At ahout the third year of infancy the epithelial homsgeon that represents the enamel-organ of the thind molar originates firom the cord of the precerding teoth, that is, the seconel pere manent molar: According to the numerons olseprations we have made, this date may be regurded as very nearly accurate, though the difficulties of which we have alrearly spoken have prevented us firm tollowing out the suceessive phases of erolution in a very riginl mammer. Yet that a little (aly) of dentine is risible in this follicle al)out the twelfth year, is true heyond a doulit.

Without continuing further the long 
analysis of the many anatomical preparations we have made, we will present a sum: mary of them all in a tabular form. In this are indicated the age and size of various embryos corresponding with the successive phases of follicular evolution. This table is the first which has yet appeared giving these in such a complete and exact manner.

An examination of this table enables one to see at a glance the different phases of dental evolution in man. The indications which it furnishes are founded on the examination of a considerahle number of sections; and consequently they appear to us to show great accuracy. Aside from their physiological interest, they not only have an important bearing upon the complex teratology of the dental system, but are especially valuable in a surgical point of view. There will be found, in fact, some valuable data concerning certain anomalies, whether in the position, direction, or in the 
difterent arrangements of the dental system. Besides they throw light upon the pathogr. ony of cretain follicular eysts and help to fix the period at which these pathologrical porluctions make their appeallance, as well as that of certain derangenents of nutrition,-the olontomes, for example. We believe, then, that it will be found service ahle in certain careses in pratetice.

The result of the olservations we lave marle on other srecies of mammals have leen less conclusive; sometimes on acomut of the head only being placerl at our disposal, and sometimes owing to the change of sime and form that they hatre experienced by prolonged maceration; and finally in conseyuence of the alsence of all statistics wathlishing the comerpondence hetween the age and length of the animal. Cere tain of them latre, howerer, enabled us to gatlele some naeful data which we will herese puesent. 


\section{THF ORIGIN AND FORMATION}

\begin{tabular}{|c|c|c|}
\hline 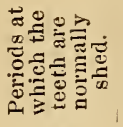 & 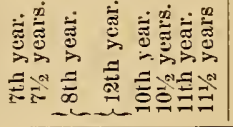 & \\
\hline 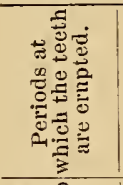 & 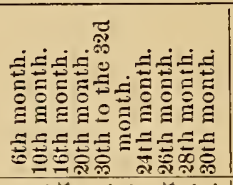 & 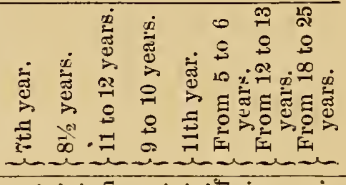 \\
\hline 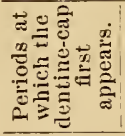 & 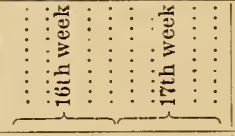 & 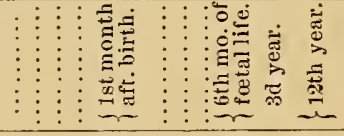 \\
\hline 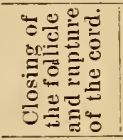 & 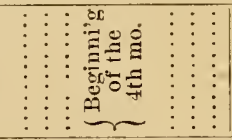 & 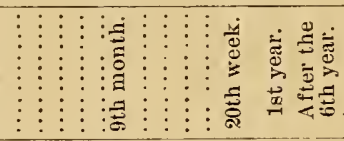 \\
\hline 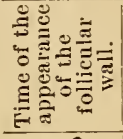 & $\begin{array}{ccccc}\vdots & \vdots & \vdots & \vdots \\
\vdots & \vdots & \vdots \\
\vdots & \vdots & \vdots & \vdots \\
\vdots & \vdots & \vdots \\
\vdots & \vdots & \vdots & \vdots \\
0 & \vdots & \vdots\end{array}$ & 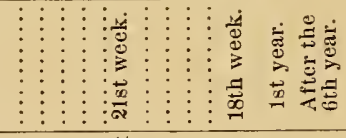 \\
\hline 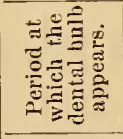 & 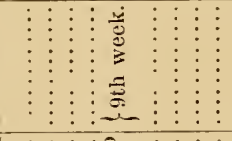 & 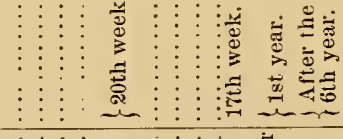 \\
\hline 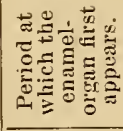 & 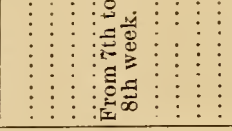 & 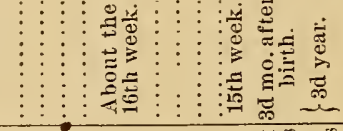 \\
\hline 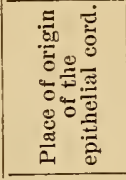 & 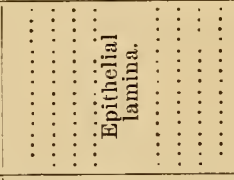 & 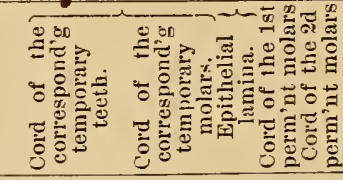 \\
\hline \multirow[t]{2}{*}{ 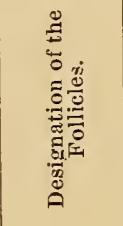 } & 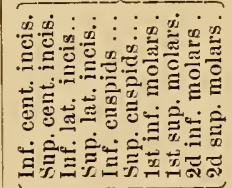 & 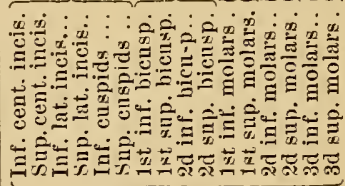 \\
\hline & 'uo & \\
\hline
\end{tabular}


In the canine species our observations have been limiterl to the examination of a few new-horn puppies; accordingly the facts concenning the aromology of the dental follicle in this animal are very few. We have, however, ancertained, that at the period of birtle, the follicles of the first dentition are already provided with a cap of dentine; that the cord of the permanent incisor's has made its appearance, and that in the centrals we can alleady discer'n the first traces of the dental bulls. In the ovine and howine species our studies have extended to a large number of embryos, hut owing to the absence of information we have not been alle to determine their exact ages. We proceed, however, to give some of on olservations, taking inte consideration simply the length of the animals cx. amined. In an ovine embryo of 42 milli. motres [ahout $1 \frac{3}{4}$ inches] in length (Figs. 16 and 19, Summun!" of I/lus.) we find on the edge of the jaws only the homrelet, 
or projecting band, with no trace of the epithelial lamina. But when the embryo has attained 52 millimetres [2 inches] we perceive the epithelial lamina well developed. (Figs. 17 and 18, Summary of Illus.) In an embryo of 65 millimetres no additional change is perceptible in the develop. ment; yet with a magnifying power of about 300 diameters one can study in this the constituent elements of the lamina. (Fig. 18, Summary of Illus.)

When the embryo has attained 72 millimetres [about 3 inches] the extremity of the lamina shows a very marked enlargement, which represents the enamel-organ of the future tooth. (Fig 21, G, Summary.)

At a little more advanced period, in an embryo measuring 82 millimetres $\left[3 \frac{1}{3}\right.$ inches], the enamel-organ and the dentinebulb have completed their formation, and the follicular wall has made its appearance at the base of the bulb. (Figs. 26 and 28, Summary.) 
When the embryo hats attained $11 \frac{1}{2}$ cent tinetres $\left[4 \frac{1}{2}\right.$ inches $]$ we olserve that the walls ane completerl, and chosed aromud the epithelial cord which is ahont to he ruprtured. At this period, also, we discorel the first appealances of the dentine caly. such alle the fiacts we have collected fiom the embryonal lambs which we have been able to prosemes.

In the borine embryo our observations, in a chronological point of view, have heen much more limited, the heads only of these embryos having been placed at our elisposal, withont any information as to the period of gestation. These specinens, how. ever, have emahled us to finnish some deseriptive details which are very distinetly shown in this aninal. (Figs : $3 S, 41$ and 42 , s'ummary.) We will state, howerer, that in at fietus of bight months we have found the temporary incisos teeth quite fully devel oped, the follicle of the permanent incisol: complete, and the dentine-cap) lexinning to form. 
Our observations have been made upon equine embryos of different ages. From these we have determined certain facts in relation to the various phases of follicular evolution. For the first three embryos we are indebted to the courtesy of M. Raynal, of the veterinary school at Alfort. In the youngest of these (14 weeks) the enamelorgan of the central nippers (incisors) are already formed, and the bulb has made its appearance. For the lateral nippers the enamel-organ is just beginning to show itself. These facts indicate that the evolution of the follicles varies in point of time in the different incisors; whereas the evolution of the follicles of these teeth in man and other manmals appears to be synchronous. For the molars, it is found that at this same epoch the bulb has appeared for all the follicles of the first dentition, as have also the first traces of the follicular wall. In a second embryo (of 27 weeks) the follicles of the central incisors are closed, 
OF THE DENTAI, FOLLICLE, - 165

while those of the first literal incisol's are just hegiming to exhihit the hulls: and those of the second lateral incisols nnly the enamelorgan. These facts, as we see, additionally eonfirm the menual development of the different incisors in this animal. In the molars the facts are anlogoms; the fol. licle of the first tenuporary molar is closed at this date, while the enamel-organ of the second has only just made its appearance, and no trace of that of the third molar is yet visible. It is at this period, also, that the first inclication of the enamel-organ appears for the tirst permanent molar.

Ii a third embryo, measuring 25.5 millimetres [10 inches], conesponding to about 28. weeks, the follicles of the permanent incisors are chosed and complete; the enamelorgan is well developed. The ameloblasts of the interiol bed and very larege, and the external epithelial layer has already disaly. peared, "hut no trace of dentine yet alpears.

* The above statement, concerning the early disappearance of the external epithelial layer of the enamel-organ. is 
The follicles of the permanent incisor's have arrived at the period when the enamelorgan already caps the bulb, which is just appearing, but is not yet constricted at its base. (Fig. 29, K, Summary.) For the temporary molars the follicles are about equally developed. They are closed and well formed, but without any appearance of the dentine-cap. The organ of coronal cement is already beginning to manifest itself. From the fragments of the ruptured epithelial cord numerous buddings have been produced.

From the fourth (an equine fcetus of $31 \frac{1}{2}$ weeks), owing to a very prolonged maceration in alcohol, we were prevented from deriving much advantage. We were only able to determine that the temporary folli. cles were fully developed and provided with caps of dentine of considerable thickness. Some fragments of the epithelial cord (long since broken, without doubt,) were still reevidently erroneous; the sections examined which led to this opinion were probably defective.-TR.] 
maining. The orom of commal cement was fully dereloped.

We will conclude these chromologrical considerations with a firw notes relative to the rodents: In an embryonal guineal-pigg of 2 centimetres [4 inch] in total lengeth, which appeared to correspond to about the midble perion of gestation, the tollicle was at the stage when the enamel-organ, in form of a hoorl, covers the bull,: there was no follicular wall or dentine-caly apparent.

In another embryo of the same species, of 4 centimetres [ $1 \frac{1}{2}$ inches $/$ in length, the temporary follicles were formed, and their stages of development were nearly the same. They were provided with a dentine-cap, covered with a thin layer of enamel. In the rablit we diseover that, at birth, the incisors hare effected their eruption, the molars still enclosed, hut alleady capped with thick layers of dentine and enamel. Beneath the temporary molars we olsepres the presence of the permament follicles, alrealy provided 


\section{THE ORIGIN AND FORMATION}

with a thin but distinctly manifest layer of dentine.

We will not pursue these considerations further, which are of less interest in the lower mammals than in man, in regard to whom we have presented a large number of examples. 


\section{CHAPTER VII.}

CRITICISM OF THEOKIES-REAUME AND CONCLUSIONS.

ThE problem of the gene-is and forma1 tion of the dental follicle in mammals lais, for a long time, been the sulject of mumerous researches, and has given rise to many theories. The relatively early period in embryonic life at which these phenomena connence; the ditticulties attending the preparation of the specimens (the treatment by diflerent reagents to which they must be suhmitted, etc.), are so many (anses which have retarded the progress of exact knowledge regarding the embryogenic evolution of these organs. The question has passed through numerous phases, and, with. out going hack rery fall in its history, and without presenting the opinions of ancient anthor's, imbued with preconceived notions 
of the nature of the teeth, or strangers to the processes of investigation of the modern anatomical·school, we will say that in going back no farther than the middle of the last century we find that Hérissant, * having conceived that he found on the surface of the mucous membrane of the gums certain small depressions, considered them to be orifices of canals communicating with the dental follicles. This opinion, which rested on no anatomical fact, was adopted by only a few authors (Bonn, 1773; Oudet, 1835). According to the theory of Hérissant, which we find at a later day more clearly presented by Goodsir, the mucous membrane of the gums would be the point of origin of the follicle, the wall of which would be developed before the follicle itself. In 1835̃, $\uparrow$ in an important work,

* Nourelles recherches sur la formation de l'émail des dents et sur celle des gencives. Mêm. de l'Acad. "Paris, 1754.

$\dagger$ Meletemata circa dentium mammalium evolutione Vratislavice. In. $4^{\circ}, 1835$, p. 12. 
Raschkow adranced the theory that the dental follicle is produced at the inner fice of the mucoms membrane, without the necessary participation of the latter; however, he does not specify which of the organs of the follicle appears first, nor how the others are produced. Nerertheless, Henle," Bischoft, † and Kölliker + (in the first edition of his microscopical anatomy) supjort his opinion. A few years later appeared the work of Goorkir, in which is formulated that well-known theory according to which both the temporary and the permanent fol. licles originate directly from the mucous menhrane itself. Inmediately aropted, without verification hy the majority of allthors, it is even now nearly the only theory fomml in the greater number of treatises on

* Aluat. gén. 1845. p. 4 1 ut swir.

† Traité du déreloppement, 1845, 1). 401-418.

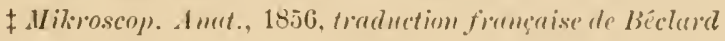
et Síe. P. 490.

$\$$ On the origin and derelopment of the pulp, and sass of the human teeth. Edinburgh "Metlical and Surgical .Journal," 1838. 
anatomy and physiology. We will not describe here this theory, according to which the follicles of the two dentitions result from a simple introversion of the mucous nembrane; it is founded on no anatomical fact, unless it be the formation of a groove which is produced on the alveolar border of the embryo by a prolonged maceration of the preparations, thus effecting the separation of the epidermic bed, which forms the epithelial band, from the groove which incloses it. It is, then, as we have said, solely by an artificial process, as Kölliker* and Kollmann + have already remarked, that the theory in question can have any appearance of reality; for nothing in the normal condition of the jaws can be found to lend support to it in any way. Not. withstanding the success of Goodsir's theory, universally accepted in England and Germany, N. Guillot published in France

*Histologique hrmaine. Edit. Trad. française, 1869.

† Loc. cit., p. 150. 
OF TIE DENTAL FOLAILE IT:

a work in which he endearvored to show that the teeth are developerl without the slightest participation of the mucous membrane; that it is fiom a mass oliginating in the depth of the emblyonal tisine that the follicle is produced. This mass he calls the initial splemoid, or prinitive trice of the trotl. He rescribes in this "spheroid" three divisions: a central one. which he names the nuclens, representing the hull, an internerliate one surromming the other, the enamel-or:gan: and lastly, the external one, which will hecome oromized to form a menbrane, he calls the dental sac. From this description, as a whole, it is eas to see that N. Gruillot has limited himself to the examination and figuring of sections made through follicles which are in an alvanced stage of evolution, ancl that he has not hit upon the mode of origin of the enmponent parts of the olgatn and their successive

* Recherches sur la gene'se et l'érolution des dents et des Mîchoires. Aun. des sc. nat., IVo śrie, t. IX, 1858. 


\section{THE ORIGIN AND FORMATION}

phases of development. This work, then, has thrown no light upon the question.

Several years later (in 1860) appeared in France an extended work, published by M. Ch. Roluin, in connection with one of the authors of this work.* This memoir contained a complete theory of follicular evolution, according to which the dental bulb is the first part of the follicle that appear's in the depth of the jaws, at the bottom of the groove and in the vicinity of the principal vessels and nerves; afterward the enamel-organ is seen; and then the wall emanating from the bulb, and rising upon the sides of these organs so as to surround them and to unite at the apex of the follicle. Whatever may be the accuracy of the descriptions in this work, it is evident that its authors misconceived the true order of the genesis of the follicle; for in reality the enamel-organ makes its appearance before the bulb.

* Robin et Magitot, Mémoire cité Journal de physiologie de Brown-Séquard, 1860-61. 
Whence comes this eror in the interpretation of the very first phenomena of follicular crolution? It results eviclently from the too exclusive mode of examination which was alopted; for the olservations were made upon preparations of follicles gradually flattened between two plates of glass. Very few sections were mate. The authors wished thereby to preserve, in their reciprocal relations all the parts which they dissected, for the purpose of further researches in detail. The fear of deforming the sections and disturbing the relations which sometimes result fiom euttings made upon masses of tissues somewhat thick, and we must say the insutticiency of the processes of hamdening known at that period,-all these combined singulinly to leal these anatomists into the error that they have there committerl.

The question was at this point, when Kölliker discovered (186:3*) the existence

* Die Entrickllung der Zahusï̈lichen ter W'iederliëner. Zeitschr. f. Wissen. Zool. 1863. Gewebelehre, 4 Aufl. 
of an epithelial band subjacent to the gingival ridge of the mucous membrane, and which extends the entire length of the jaws. This continuous lamina Kölliker' calls the enamel-organ; but we regard it only as a simple dependence of the epithelial band. The term enamel-organ does not appear to us to be appropriate to a lamina which does not contribute directly to the formation of the follicle, since it is upon a certain number of points of this that bourgeons appear, from which the enamel-organs are directly developed. These bourgeons are in number equal to that of the future teeth; and in the intervals between the bourgeons, or enamel-organs, the epithelial lamina remains unchanged.

Whatever may be said of the interpretation of them, the views of Kölliker are very just; and they became the starting-point of a series of observations which gave to the question of the evolution of the dental follicle an entirely new aspect. Two facts 
were firm that time settled, namely, that the enamel-organ alpears as the first constituent pout of the follicle, and that its origin is epithelial. L Lon this last point the views previonsly put forth hy Marcusen and Huxley were confirmed.* Following the work of Kölliker are grouped a considerable number of researches emanating from his pupils, or coming fiom other German schools. Such are the memoires of $\mathrm{W}_{\mathrm{al}}$ deyer, Hertz, Wendzel, Kollmann, etc. $\uparrow$

* Alareusen, Urber die Entricklung der Zähne. Bulletin de l'Acad. impériale de Saint Pétersbourg, 1849. Huxley, Qutent. Sourmal of Microscopical Science. 1854, 1855, 1857.

† Waldeyer. Untersuch, über die Entwicklung der Zühne: I Abth. Königsberg und Jahrbïcher IV, Bd. 1864; II Abth. Zeitschr. fur rat. Med.; III, 24 Bd, 1865.-IT. Ban und Entricklung der Zuihne in Stricker, IIandbuch der Lehre ron den Gerreben. Leiprig, 1871, p. 333 et suiv.-Hertz, Untersuchungen ïber feincren Bau und die Entwicklung der Zühne. V'irch. Arch. 1866, Bd. 37; id., Ein Fall ron geheilter Zahnfractur mit nachfolgemiler Schmelzbildung. Virch. Arch. 1866. 38 Bd.-Wendzel, Untersuchungen iiber. das Schmelzorgan und den Schmelz. etc. Arch. ron Hekde. 1868, p. 47.-Kollmann, Entwicklung der Vilch und Er'sutzzühne beim Menschen. Zeitschrift für. Wissenschuftliche Zoologie. von Seibold und Kölliker: Zwanzigster Band, Zweites Heft, p. 145. Leipzig, 1870. 
178 THE ORIGIN AND FORMATION

In these different works the idea of Kölliker is taken at the initial point. Wal. deyer described exactly the descent of the cord, and the formation of the component parts of the follicle. He indicates, also, that the follicles of the permanent teeth arise from buddings from the primitive cords; but he fails to mention, in regard to them, the different modes of genesis, and also the precise points where this genesis takes place. He points out, moreover, in his last publication," the unsettled difficulties which exist in these questions, notwithstanding the numerous works published npon this subject. Hertz and Wendel support the opinions promulgated by Kölliker and Waldeyer, without adding anything new to the question of the origin of the follicle. They have, howerer, advanced some new ideas upon other points of follicular evolution, which we will discuss on another occasion. As to Kollmann, the last German anato-

* See in Stricker, loc. cit. 1871, p. 352 (English Edition). 
mist who has studied the question, he arlopts mulesitatingly the views of Köliker and Waldeyer on the suliject of the origin of the enamel-organ of the temporary teeth; but in regand to the origin of the permanent follicle, sometimes he derives it lirectly from the mucoms membrane, sometimes from the epithelial débris of the primitive cord, and at others from an epidernic glohule. It is also fiom one of these last that hé makes the supernumerary follicles arise, as we have already mentioned.* 'The Ger' man authors are, then, very fiur from agree. ing, as we see, in regard to the mole of origin of the dental follicle. As to the phenomena which take place within that organ after the origin of the hulh, and the formation of the wall, and the transformation of the enamel-olgan, they are still in controversy. In oul opinion, and we maly thus in a few works resume on work, the formation of the dentil follicle consints, es.

* [See p. 66 of this work.-Tr.] 
sentially, in the genesis of two organs, one of which is of an epithelial nature, emanating from the epithelium of the mucous membrane, the other of an embryoplastic nature, originating in the midst of the embryonic tissue of the jaws. The first of these is the enamel-organ, the second is the bulb, or dentine-organ; thus they are formed individually and then proceed to meet each other. The enamel-organ becomes in a manner the cap of the bulb, while from the base of the latter emanate membranous processes, which envelop little by little the two organs, and at last entirely close the follicle. If one examines the origin and growth of these organs from the point of view of general physiology, he is immediately struck with the extreme analogy they present to the phenomena of the formation of the hair-follicles. In the latter, as well as in the former, one sees on the one hand an epithelial cord which descends from the Malpighian layer into the dermis; then on a 
point of the latter alpleals the hull, which penetrates the former, and makes of it a cap for itself; while firom its hase emanate those processes which are to form the walls of the follicle. These fiacts show the close analogy of these two organs. (Fig. 40.)

Thus we find confirmed, by actual physiological and embryological facts, the theory enunciated a long time since by De Blainville, regarding the analogy in the composition and formation of the phaneres, as well as the doctrine of the products developed with so much precision in the modern anatomical school of Ch. Rolin.

CONCLUSIONS.

1st. 'The dental follicles first appear as a cord emanating fiom the epithelial layer of the oral mucous menthane.

2d. The cords that give origin to the follicles of the first dentition arise directly from a process of the oral epithelium (epi- 
thelial band and epithelial lamina). The cords for those permanent teeth which succeed the temporary ones are diverticula or outgrowths from the primitive cords. As for the cords of the other permanent teeth, those for the first molar's originate directly from the epithelium of the mucous membrane, and the remaining ones (eight in number) from the cords of the preceding molars. (See table.)

3d. The cord, whatever may be its point of origin, is invariably epithelial ; it is composed outwardly of a layer of prismatic elements of the Malpighian stratum, and in the interior, of polyhedric epithelial cells.

4th. The extremity of the cord, which soon takes the form of a club-shaped swelling, constitutes the enamel-organ of the future follicle.

5th. The dental bulb appears spontaneously in the midst of the embryonic tissue and at a point in immediate proximity to the deeper face of the enamel-organ. 
6th. The enamel-organ cover's the bulb, serving as a calp for it; all armongement which continues during all the periods of evolution, preceding the formation of the dentine and the enamel.

7th. The follicular processes emanate directly from the elements of the bulb, and rise from its base to the summit of the follicle, where they unite and constitute the follicular sac.

Stl. Synchronous with the closing of the follicles is the rupture of the cord; and from this perior the follicle loses all connection with the epithelium of the mucous membrane. The formation of the follicle is now complete.

ath. 'The erolutionary phenomena of the follicles in hoth dentitions are identical as to their nature; the only perceptible differences are in regard to the exact point from which the epithelial cords originate, and the length of time necessary to accomplish their successive phases of erolution. 
10th. The mode of evolution of the dental follicle and of the pileous follicle is identical.

Frank : Are, then, onr readings to terminate here?

TEACHER: The appearance of the second memoir in the series has been long delayed, owing to the death of one of its anthors, the lamented Dr. Ch. Legros. Mnch of the materials for this, I am informed, had been collected before his decease; but the preoccupation of Dr. Magitot has prevented his completing it up to the present time. I am, however, daily expecting the arrival of this treatise, and, should it be found desirable, we may resume our readings.

If you have obtained a clear idea of the phenomena of the origin and growth of the dental follicle from the present work, you have acquired far more than has been hitherto taught in any of our medical or dental schools, or can be found in any other publication upon this subject; and thongh it will, doubtless, become necessary for yon to modify your views in some particular's, as this branch of science progresses, yet the knowledge you have here gained will enable you to readily perceive and appreciate the value of future researches made either by yourselves or by other observers in this field of study. 


\title{
SUMMARY OF ILLUSTRATIONS
}

\author{
AND A BRIEF \\ DESCRIPTIVE REVIEW.
}

All figures not accredited to other somrces are copied from the original work.

The dental bulbs, in some of the following figures, present a rascular appearance, not seen in those from which they are copied. It was believed that by thus representing them, the student might more readily recognize the diferent parts of the developing follicle. 
Frg. 1.-This diagram shows the relative position of the different layers which are designated the mucous, or "proper " mucous, membrane by various writers. The column on the left gives the names and location of the strata of the mucous membrane as we think they should be designated. The horizontal lines show the relative location of these layers, without any regard to their thickness. M. S. D., del. (See p. 11.)

Fig. 2.-This cut was designed to illustrate the cells of the epidermis $E$, in some of their various phases, as described (p. 18 et seq.) a, Stratum corneum; $b$, stratum Malpighii, with its prismatic or columnar layer resting upon the basement membrane, $b m$; $c$, upper portion of the dermis. The papillæ are not represented in this figure, nor the subdermal layer. M.S. D., del. (See p. 18 et seq.)

Fig. 3.-The so-called "spinous," "ridged," "imbricated," "aculeated," "prickle" or "heckle" cells. Frey. (See p. 59.)

FIg. 4.-Showing the lowest layer of the Malpighian stratum $(a)$; the intermediate matter $(b)$; the basement membrane $(c)$; and the fibrous tissue of the dermis $(d)$. (From Frey. Diagrammatic.) Though the cells of this layer always stand nearly perpendicularly, their form is varied; for example, the basal extremities are truncated in the ameloblasts, somewhat like those seen in Fig. 7, p. 191. (See p. 21.)

Fig. 5.-Stellate cells, such as compose the "stellate reticulum " of the enamel-organ. Diagrammatic, from Frey. (See p. 77.)

Fig. 6.-Cut to represent the basal aspect of a layer of ameloblasts; showing their prismatic or hexagonal form. M. S. D., del. (See p. 85.) 
Fiti. I.

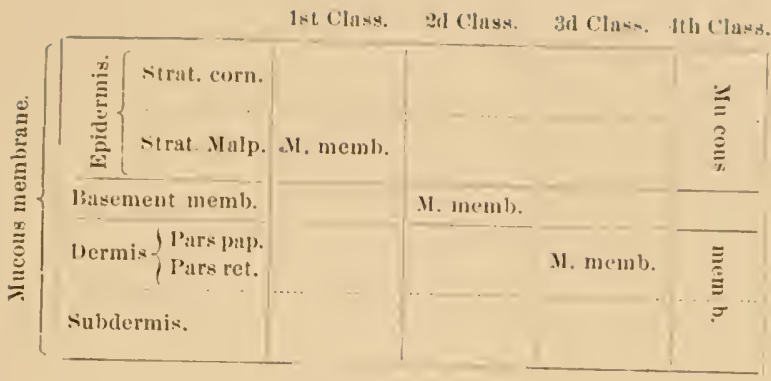

Fig. :

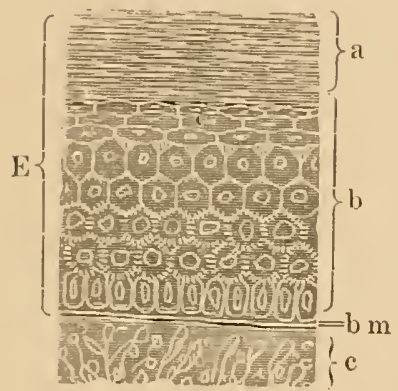

Fig. 5.

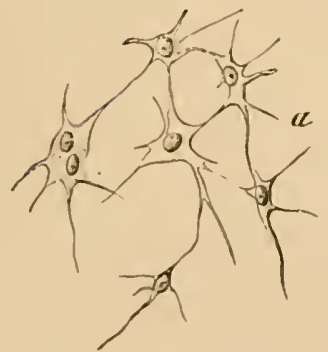

FIG. 3.

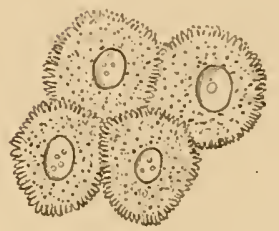

Fig. 1.

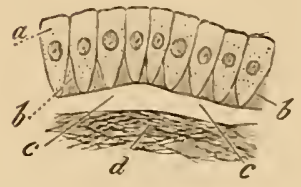

Fig. 1 .

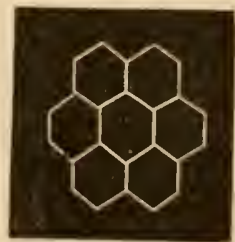


FIG. 9.-Meckel's cartilage; from a human embryo of forty to forty-two days. (Magnified 25 diam.)

a, Enlargement of cartilage near the neck of the malleus; $b$, the mental symphysis where the two homologous parts unite; $m$, head of the malleus; $n$, handle of the same; $e$, cartilage of the incus; 0 , that of the os lenticulare; $l$, that of the stapes. One side of the jaw has been outlined to show the relative position it will occupy when ossification takes place. (For further description of this and following figures, see p. 32 et seq.) Magitot and Robin.

Frg. 10.-Cranium of a human fœtus of four months; natural size; showing the membrane of the tympanum, with the cartilages of the incus and malleus $(b)$; also the extra-tympanic portion of Meckel's cartilage (a). Magitot and Robin.

Frc. 11.-Right inferior maxilla of a human embryo of about three months; natural size. Soft parts removed from the internal face, showing relative position of Meckel's cartilage. $a$, Extra-tympanic portion; $b$, symphysis; $n$, manubrium mallei (handle of hammer); $e$, incus (or anvil). Magitot and Robin.

FIG. 12.-From a human embryo of about sixty days; natural size. Soft parts removed, showing Meckel's cartilage and lingual face of the jaw-bone, left side. In this the cartilage has much the appearance of a very large bristle. $A$, Extra-tympanic part; $b$, symphysis; $n$, malleus. M.S. D., del.

Fig. 13.-From a foetus of four months; showing the palatal aspect of the inter-maxillary bones. M.S. D., del. (See p. 40.) 


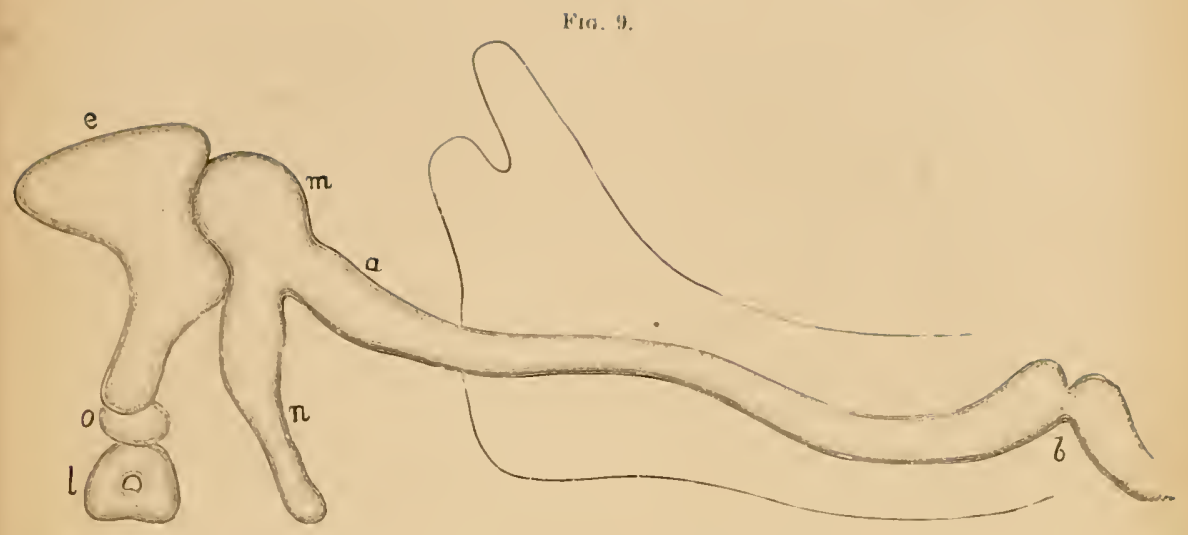

FIG. 11.

FIg. 10.
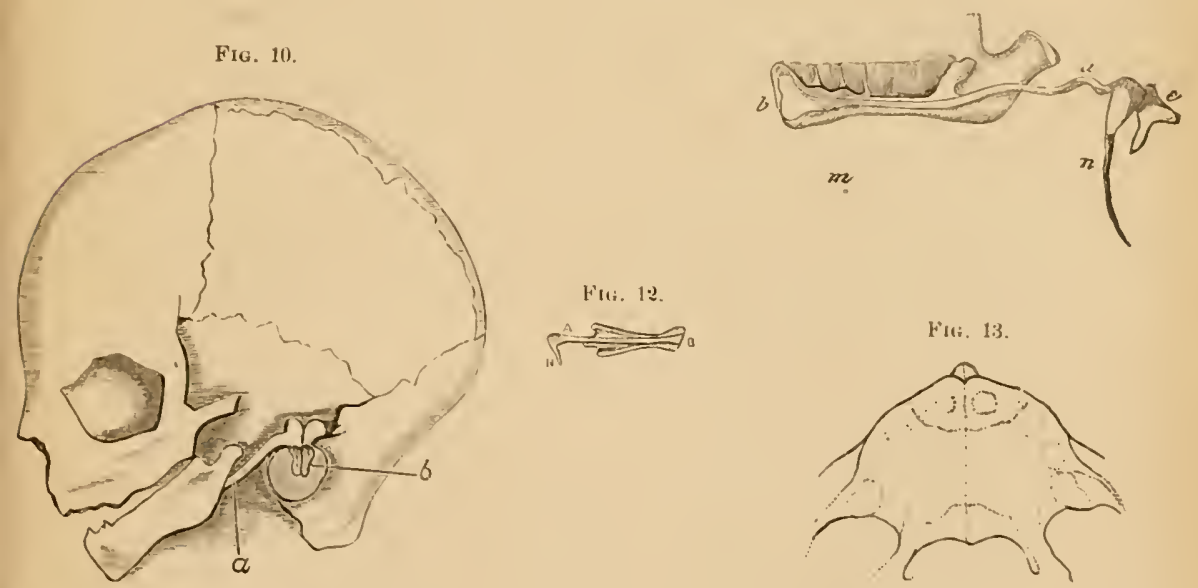

Fili, 12.

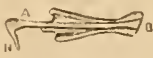

FHIt, 13 .

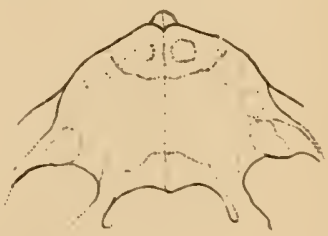


FIG. 14.-Vertical section of the anterior part of the face of a human embryo of about 45 days, measuring 3 centimetres [1//4 in]. (Magnified 80 diam.)

$a, a$, Meckel's cartilage; $b$, first trace of the submax. glands; $c$, depression of the mucous membrane; $d$, epithelial band, bourrelet of the lower jaw (see description, p. 51 et seq.): $d$, epithelial band of upper jaw; $E$, section of the tongue; $F, F, F, F$, oral cavity, a thin bed of epithelium clothes its surface; $g$, upper jaw; $H, H$, incisive (or intermaxiliary) bourgeons, which have already united at the median line.

This central line does not appear in the original figure, and should terminate where it enters the lighter part. (See description, p. 149.)

Fig. 15.-Embryo of 40 days, showing the mouth and palatal region. (Coste).

1, First appearance of the nose; 2, 2, alæ of the nose; 3 , closure of the incisive processes; 4 , median portion of upper lip, formed by the approach and union of the two incisive (or intermaxillary) processes, the little notch in the median line still indicating the primitive separation of the two processes. (See p. 29.)

FıG. 7.-Taken from Kölliker's Manual of Hist., showing "a simple papilla [of the mucous membrane], with manifold vessels and epithelium, from the gums of an infant. (Magnified 250 diam.)" It is given here principally to show the cells of the epidermis. (See p. 26.) 
Fis. 14.

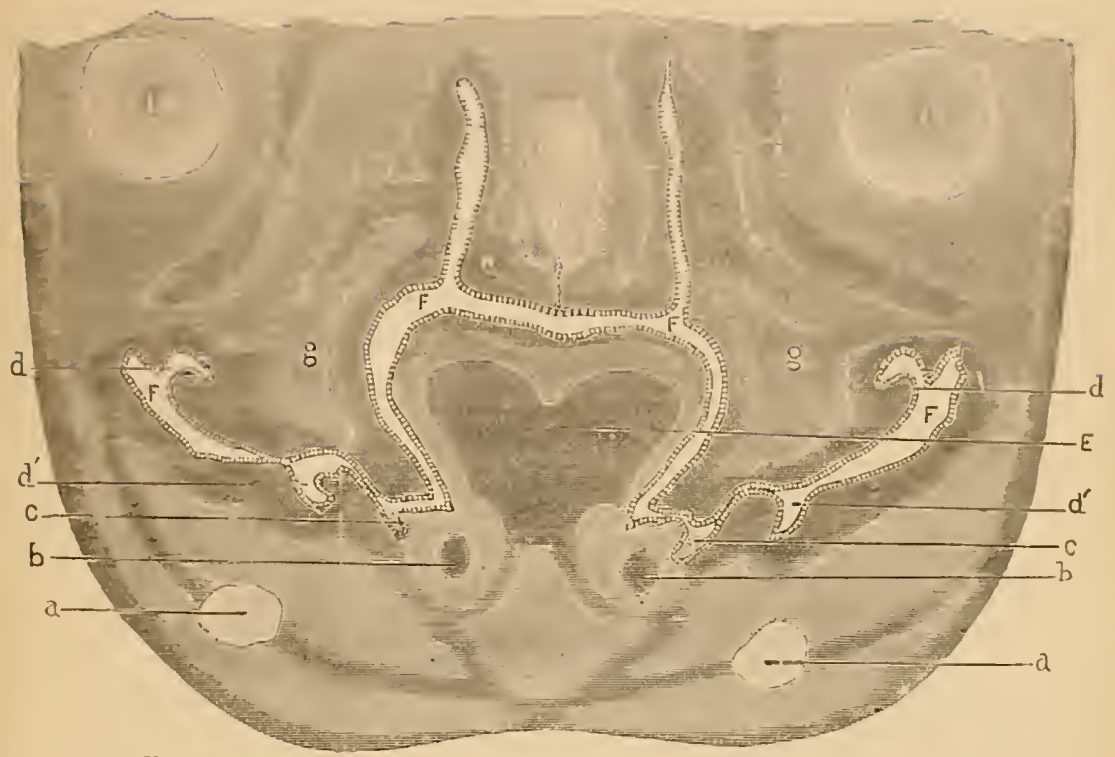

FIG. 15 .

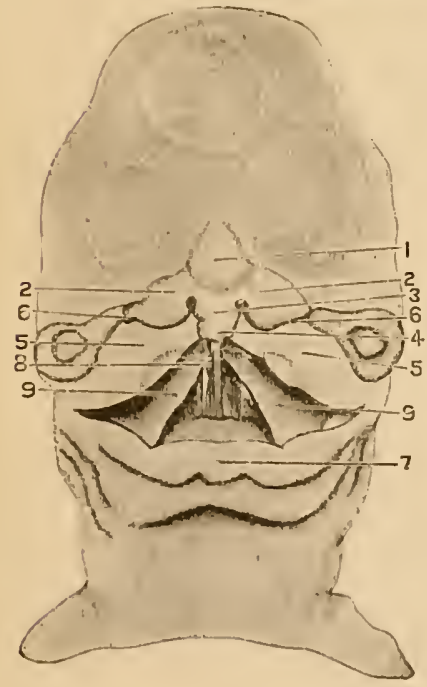

FIg.
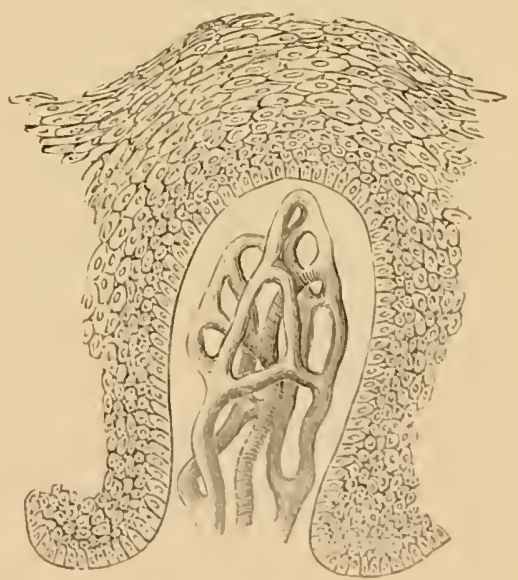
Fir. 16.-Vertical section taken from the incisive region of an ovine embryo, 42 millimetres [ $13 / 4$ inches] in length. (Magnified 80 diam.) a, Meckel's cartilage; $c$, depression of mucous membrane; $d$, epithelial band. The close proximity of the parts of the severed cartilage shows the cut to have been taken from the anterior portion of the jaw. (See p. 53.)

FIG. 17.-Vertical section of the anterior portion of the lower jaw of an ovine embryo, 59 millimetres [about 2 inches] in length. $E, E$, epithelial lamina, emanating from the epithelial band. The letters $a, c, d$ refer to the same parts as in the preceding figure. (See p. 63.)

Fig. 18.-Vertical transverse section of the left branch of the Jower jaw of an ovine embryo, 65 millimetres. (Magnified 260 diam.) This and Fig. 17 show the arrangement of the elements of the epithelial band, and also the epithelial lamina. $d$, Epithelium of the mucous membrane, extending nearly vertically into the embryonal tissue and constituting the epithelial band, and the lateral process or epithelial lamina.

E, Epithelial lamina, emanating from the band. The band and lamina are surrounded by the embryonal tissue of the jaw. This portion of the engraving is faulty, in that the nuclear elements appear lighter, whereas they should be darker, than the surrounding mass. (See p. 63 et seq.)

Fig. 19.-From a porcine embryo (copied from Frey). $d$, Mass of epithelium, - the "dental ridge," "maxillary rampart " or "kieferwall "; $b$, younger layer of epithelium; $c$, deepest layer,- the columnar or prismatic stratum; $e$, enamel-organ. (See p. 52.) 
Fig, It).

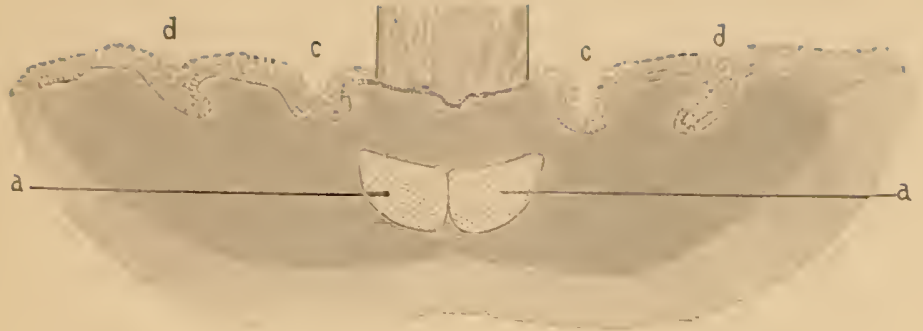

Fig. 1 .

d

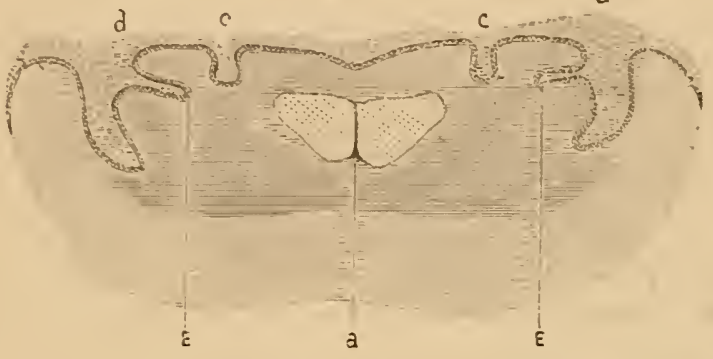

Fig. 18.

คิเ 19.

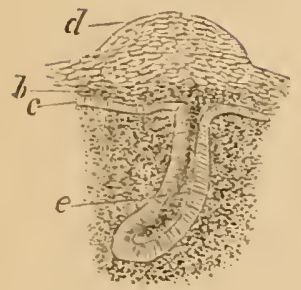

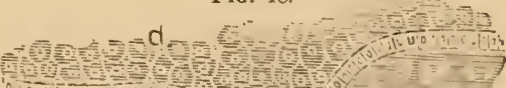
$0.091010 .120391901010=0$

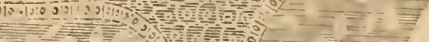

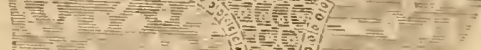

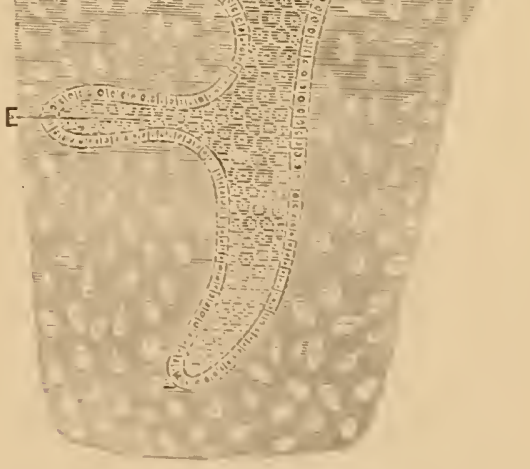


Fig. 20.-Section from an embryonic lamb a little older than that from which Fig. 18 was taken; showing the epithelial lamina. (Magnified 350 diam.) $c$, Prismatic or columnar cells, - a continuation of the lowest layer of the Malpighian stratum; $d$, large polygonal cells of the epithelial band (bourrelet); $E$, smaller polygonal cells of the epithelial lamina. The lamina now presents an enlarged extremity, and this is the rudiment of the enamel-organ. (See p. 69.)

Fig. 21.-From the lower jaw of an orine embryo (left side), measuring 72 millimetres $\left[2 \frac{6}{6}\right.$ inches]. (Magnified 80 diam.) $d$ and $E$ same as in preceding figures; $g$, rudimental enamel-organ. (See p. 70.)

FIG. 23.-From a borine embryo (Wedl). d, Epithelial band ("dental ridge"); $b$, enamel-organ ("follicular process"); c, epithelium of the margin of the under lip, with rudimentary hair-follicles. (Magnified 15 diam.)

FIa. 24.-From the incisive region of an ovine embryo, lower jaw, 115 millimetres [ $4 \frac{3}{5}$ inches]. (Magnified 80 diam.) $a$, Meckel's cartilage; $b$, osseous trabeculæ; $c, c$, dental artery; $d$, epithelial band; $E$, epithelial lamina; $f$, cord; $g$, enamel-organ; $H$, ludimentary bulb.

In this figure, which has been drawn from nature, as well as all the others, certain defects, which have resulted from too long maceration, have been preserved in the drawings; hence the space seen between the follicular wall $(I)$ and the enamel-organ $(g)$ is artificial, and does not appear in fresh preparations. It will be seen, on the right side of the figure, that the cut was not in line with the follicle, and that only the lamina is apparent. 
Fic. 25.-From lower jaw of an equine embryo, 190 millimetres [ $7 \frac{3}{5}$ inches] in length. (Magnified 80 diam.)

$a$, Meckel's cartilage; $b$, traces of ossification; $E$, epithelial lamina; $F$, cord: $g$, enamel-organ; $H$, bulb; $I$, follicular wall. This figure shows the same defect alluded to in Fig. 24.

FIg. 26.-From lower jaw of an ovine embryo, 82 millimetres [ $3 \frac{1}{4}$ inches] in length. (Magnified 80 diam.)

a, Meckel's cartilage; $E$, epithelial lamina; $F$, epithelial cord; $g$, enamel-organ; $H$, bulb; $I$, follicular wall; $K$, secondary bourgeon, from which the enamel-organ of the permanent tooth originates.

Frg. 27.-From lower jaw of a bovine embryo, magnified 80 diameters.

$a$, (in the center of the figure), Meckel's cartilage; $b$, traces of ossification; $d$, oral epithelium; $E$, epithelial lamina; $F$, epithelial cord; $g$, enamel-organ; $H$, dental bulb; $I$, “internal epithelium," or layer of ameloblasts; $I^{\prime}$, external epithelium of the enamel-organ; $K$, secondary enamelbourgeon. 
Fig. 25.

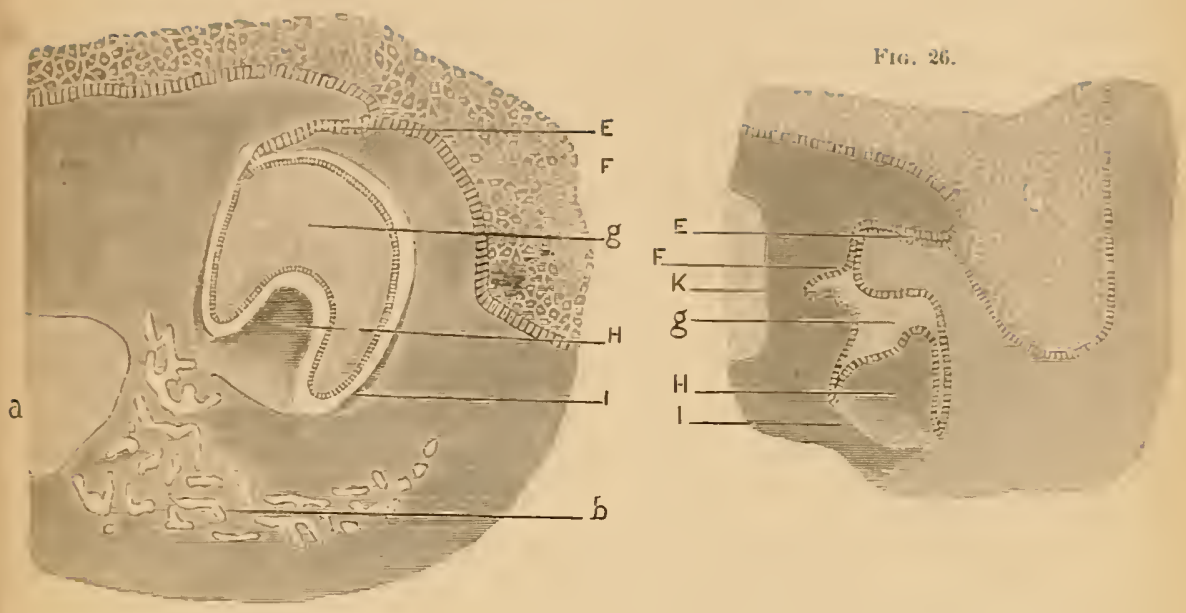

FIG. 2ิโ.

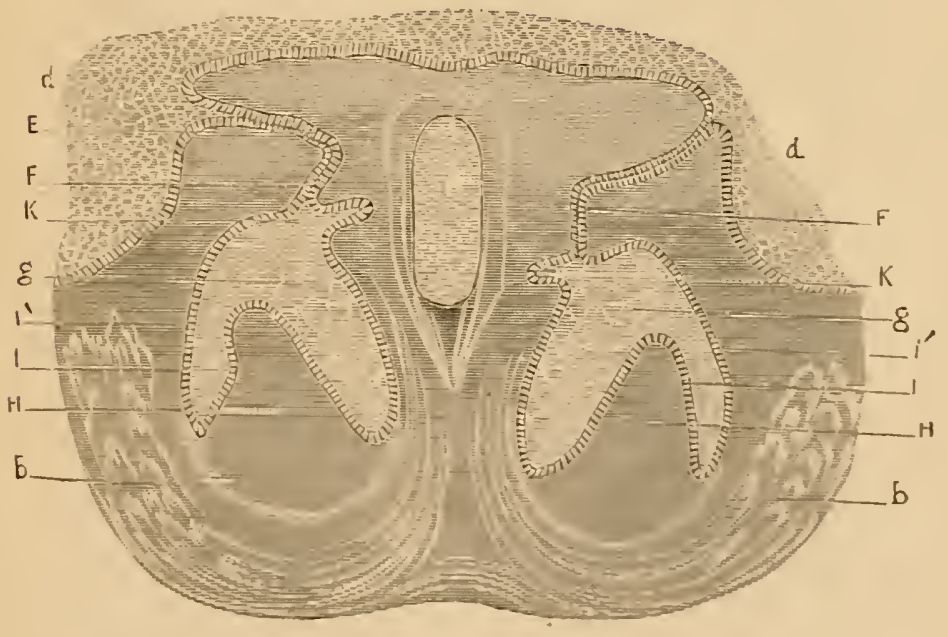


FIG. 8.-Ideal dental follicle, before the rupture of its cord. Drawn solely to show the position of the basement membrame, and the preformatice membranes of Raschkow and Huxley. (For full description, see p. 89.)

$B M$, basement membrane; $N$, neck; $S$, sac or follicular wall; $O$, enamel-organ; $B$, bulb; $E E$, external epithelium of the enamel-organ and the basement membrane; $E C$, epithelial cord; $C T$, connective tissue surrounding the enamel-organ; $E p$, epiclermis or oral epithelium.

The parts embraced between the points where the divergent lines $A A$ terminate are: (1) the concave face of the enamel-organ, lined with a layer of ameloblasts, or the "internal epithelium "; (2) the membrana præformativa of Huxley, or the tissue composed of the basal coverings of the ameloblasts; (3) the menbrana præformativa of Raschkow, or the basement membrane; (4) the dentine-bulb itself.(Diagrammatic.) M.S. D., del.

FIG. 28.- Section through the incisive portion of the lower jaw of an ovine embryo, measuring 82 millin. [ $[31 / 3$ inches] in length. (Magnified 260 diam.)

$d$, Oral epithelium; $c$, lowest layer of cells in the stratum Malpighii; $F$, epithelial cord; $K$, bourgeon of the secondary cord; $I$, follicular wall; $H$, dental bulb. (See p. 162; also Fig. 26.)

FIG. 29.-Vertical section of the anterior portion of the lower jaw of an equine foetus, 255 millimetres [10 $\frac{1}{5}$ inches] in length, and corresponding to about 281/2 weeks. (Magnified 80 diam.)

$a$, Meckel's cartilage; $b$, traces of ossification; $d$, oral epithelium; $g$, enamel-organ; $H$, bulb; $I$, layer of ameloblasts; $K$, bulb of the permanent tootl, capped by the enamel-organ, with some traces of the secondary cord; $L$, place assigned for the development of the cement. (See description, p. 165.) 
Fiti, 8 ,

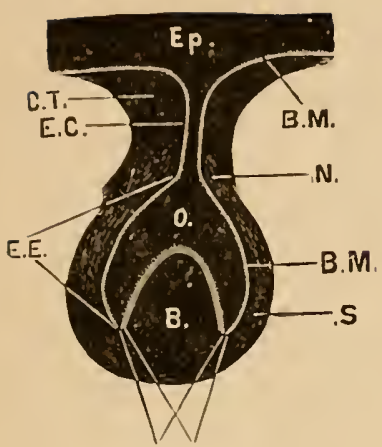

A. A.

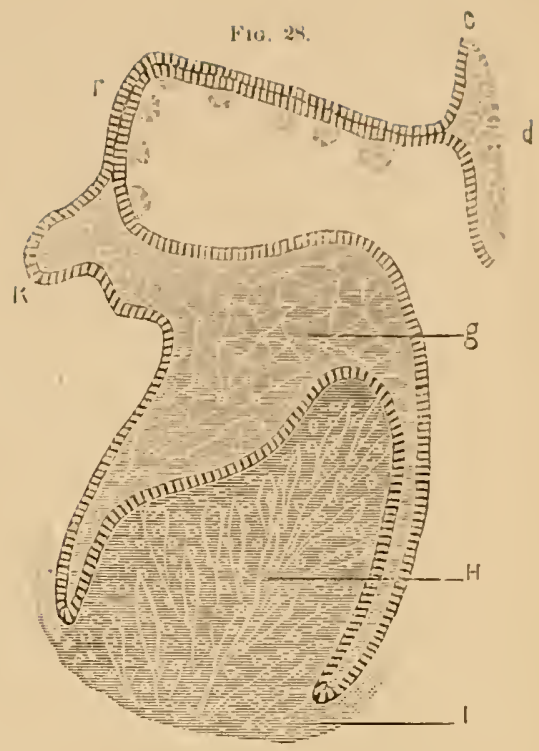

FIx. 29.

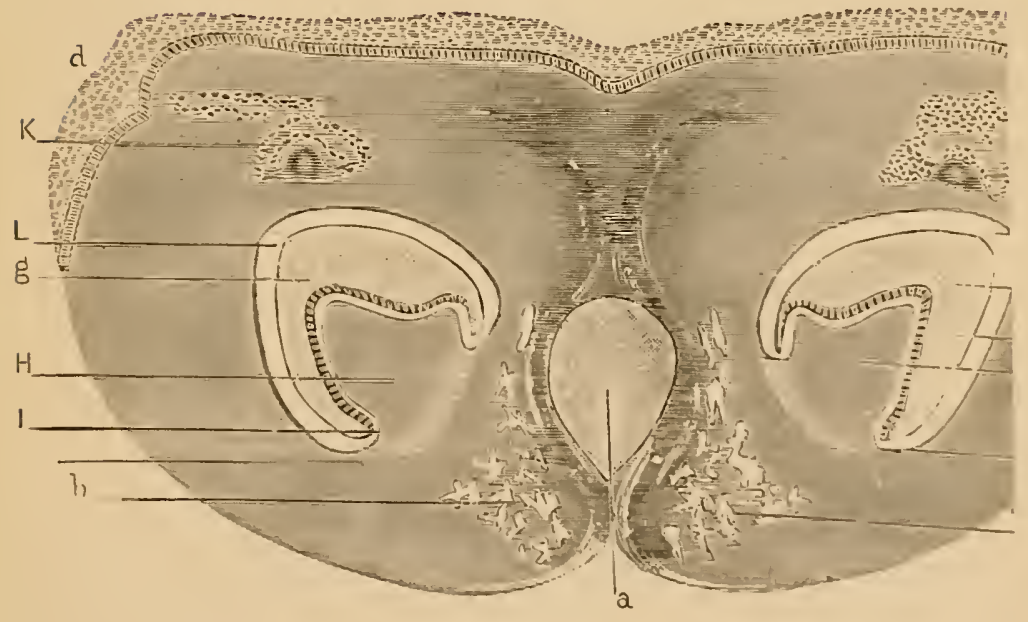


Figs. 30 AND 31.-These cuts are taken from the incisive region of different human foetuses, evidently not far from the sixteenth week of gestation. A detailed description of the figures would be unnecessary. The cuts are introduced here simply because they present one peculiarity that is not represented in the other figures, viz, the origin of the epithelial cords for the permanent incisors directly from the epithelial lamina, instead of their being offshoots from the cords of corresponding temporary follicles. These are designated by the letters $E$ on the right of the figure.

Though these figures seem to establish the fact that the teeth of replacement are sometimes derived directly from the epithelial lamina, yet we must not regard these as conclusive evidence until they are fully verified by other skillful histologists.

For the drawings of these I am indebted to my friend Dr. Black. (See description, p. 137.) 

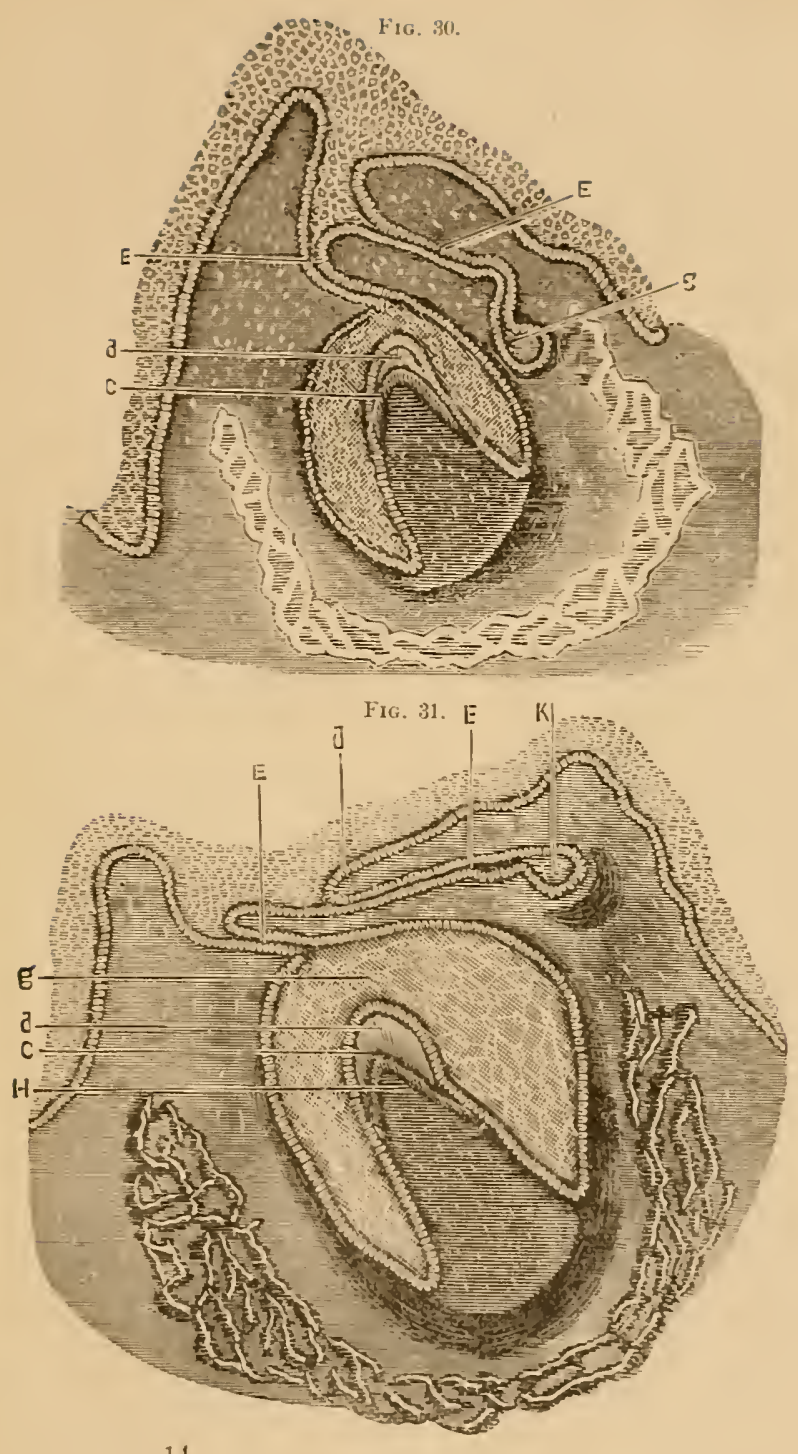
Frg. 32.- "From the upper jaw of a kitten about the time of birth.

$a$, Oral epithelium; $b$, bone of jaw; $c$, neck of enamelorgan; $d$, dentine papilla; $e$, enamel-cells; $f$, stellate reticulum; $h$, tooth-germ of the permanent tooth, the enamelorgan of which is derived from the neck of its predecessor."-From Tomes" Man. of Dent. Anat.

Fic. 33.-A cut through the follicle of a lower temp. molar of a human foetus, 20 centimetres [8 inches] in length; about the seventeenth week of gestation. (Magnified 80 diam.)

$a$, Meckel's cartilage; $b$, traces of ossification; $c, c$, dental artery and nerve; $d$, epithelium ; $E$, enamel-organ; $F$, cord of the temporary follicle; $H$, bulb; $I$, follicular wall; $K$, cord of the permanent follicle. (See p. 152.)

Fig. 34.-Section of the lower jaw of a human foetus, $231 / 2$ centimetres $\left[9 \frac{1}{5}\right.$ inches] in length; corresponding to about the eighteenth week. (Magnified 80 diam.)

$K$, Cord or bourgeon of the secondary follicle; $L$, point where its separation from the primitive cord is being effected; $a$, Meckel's cartilage diminished by absorption; $b$, bone of the jaw; $c$. (upper) dental artery, (lower) dental nerve; $d$, epithelium; $E$, originally the cord of the temporary follicle, but now the sole property of the permanent one. (See p. 153.) 
Fig. 32.

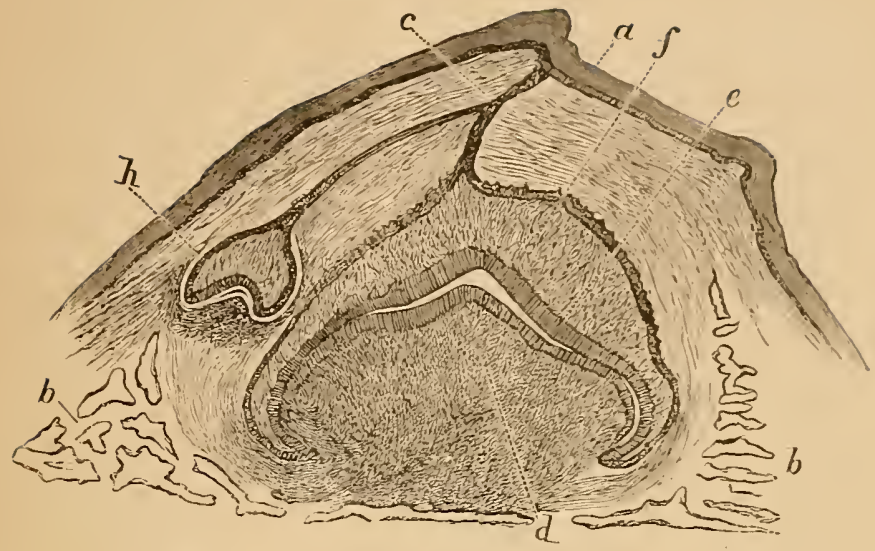

FIG, 33.

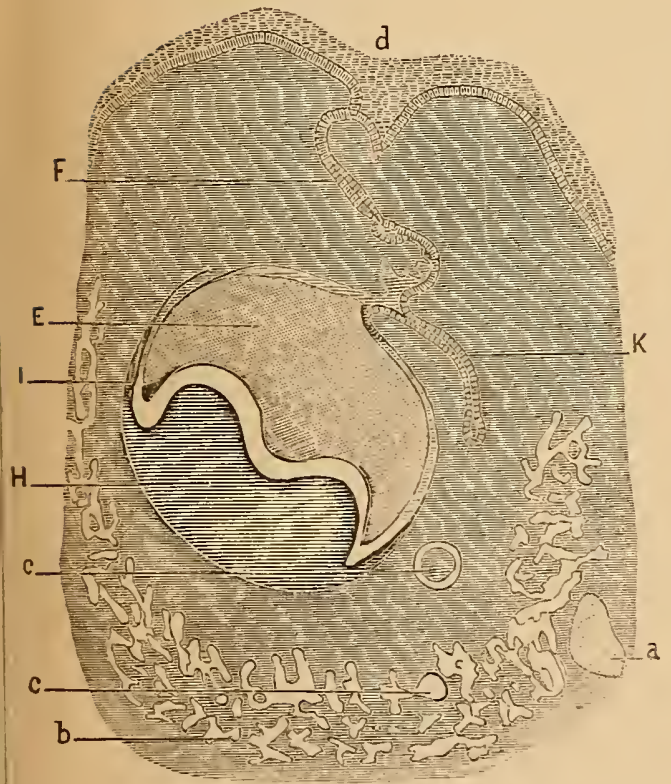

FIG, 34.

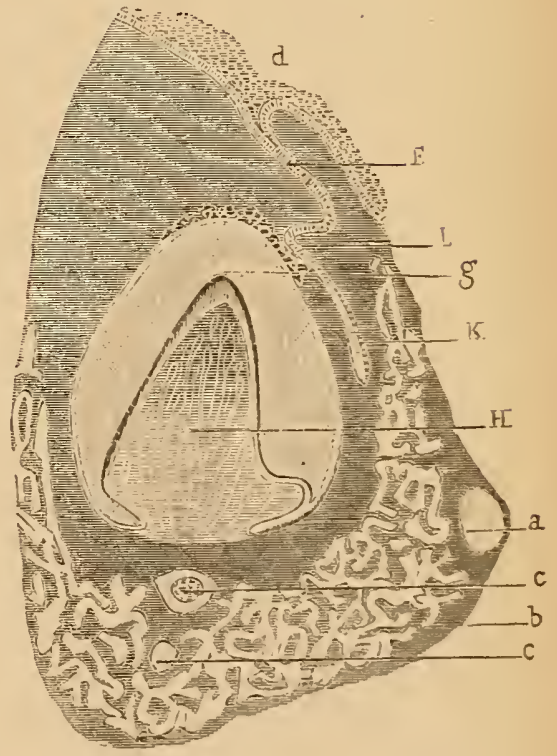


FIG. 35.- Section on a line with the follicle of the first permanent molar. Human subject, three months after birth. (Magnified 80 diam.)

$b$, Maxillary bone; $c, c$, dental artery and nerve; $E$, cord of the follicle of the first permanent molar; $g$, enamelorgan; $H$, bulb of the first permanent molar; $K$, bourgeon of the enamel-organ of the second permanent molar. (See p. 156.)

Fig. 36.-Vertical section of the lower jaw of a human fœetus, measuring 47 centimetres [ $183 / 4$ inches]; corresponding to nearly the thirty-ninth week of gestation. The figure represents a cut passing through the follicle of a bicuspid.

$b$, Bone of the jaw; $d$, oral epithelium; $g$, enamel-organ; $H$, dental bulb; $K$, débris of the cord of a permanent follicle; $K^{\prime} K^{\prime}$, epidermal globules. Follicle for the permanent tooth counected with the débris of its cord, $K$.

FIG. 37.-Vertical transverse section through the incisive region of the lower jaw of a human foetus, measuring 38

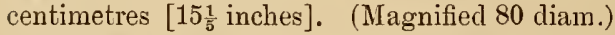

$b$, Bony formation; $d$, oral epithelium; $g$, enamel-organ; $H$, dental bulb; $I$, cord of the permanent follicle; $K$, débris on the follicular wall of the primitive follicle and from its cord; $K^{\prime}$, epithelial globule; $L$, enamel-organ of the permanent tooth. 
FIเ: 35.

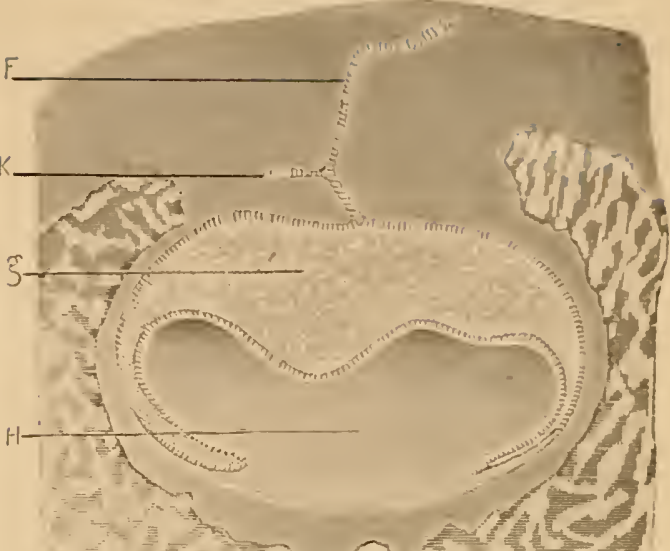

FI(i. 3ti. $\quad$ C

$\because 4 \quad b \frac{1}{1+0}=-10$
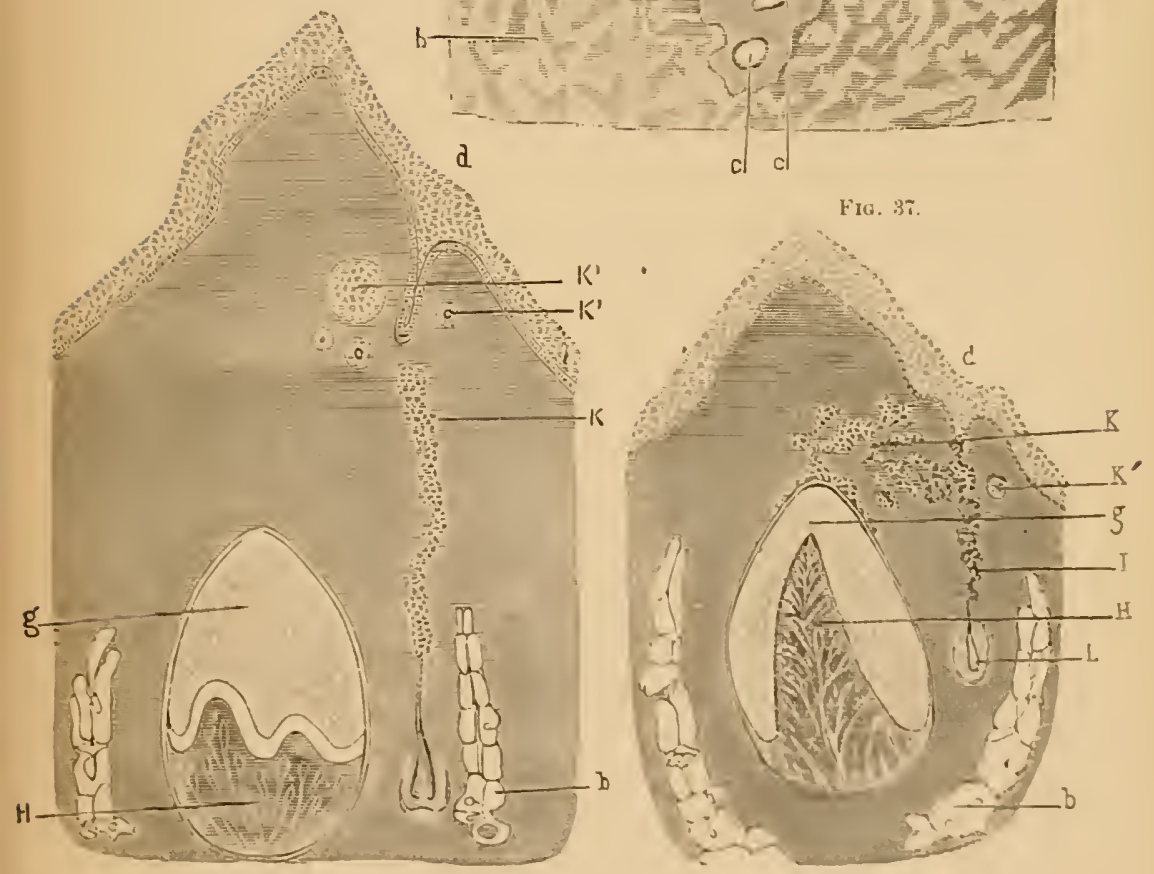
Fig. 38.-From the lower jaw of an ovine embryo, magnified 80 diameters; showing the completed dental follicle and the surrounding tissues.

$a$, Meckel's cartilage; $b$, traces of ossification; $c$, lowest layer of the epithelial cells; $d$, oral epithelium; $F$, ameloblastic layer; $F$, (lower) external layer of the enamel-organa continuation of the layer of ameloblasts; $g$, stellate reticulum of the enamel-organ; $H$, bulb; $I$, follicular wall; $K$, buddings from the cord.

Fig. 39.-From a human embryo, 20 centimetres [8 inches] in length. (Magnified 80 diam.)

$a$, Meckel's cartilage; $b$, bone; $c, c$, artery and nerve; d, oral epithelium; $E$, cord of the first permanent molar originating from the lamina; $F$, débris of the cord of the preceding follicle; $g$, muscular insertions. (See description, p. 155).

EIG. 40.-A section of the skin of a human fotus, 20 centimetres [8 inches]; about the seventeenth week of gestation; showing the complete analogy in the development of the hair and the teeth.

. a, Pilous follicle quite well developed, with its bulb forcing back the epithelial cells and forming a cap for itself; $b$, simple epithelial bourgeon; $c$, epithelial bourgeon, with the bulb just appearing. 
Fin, 38.

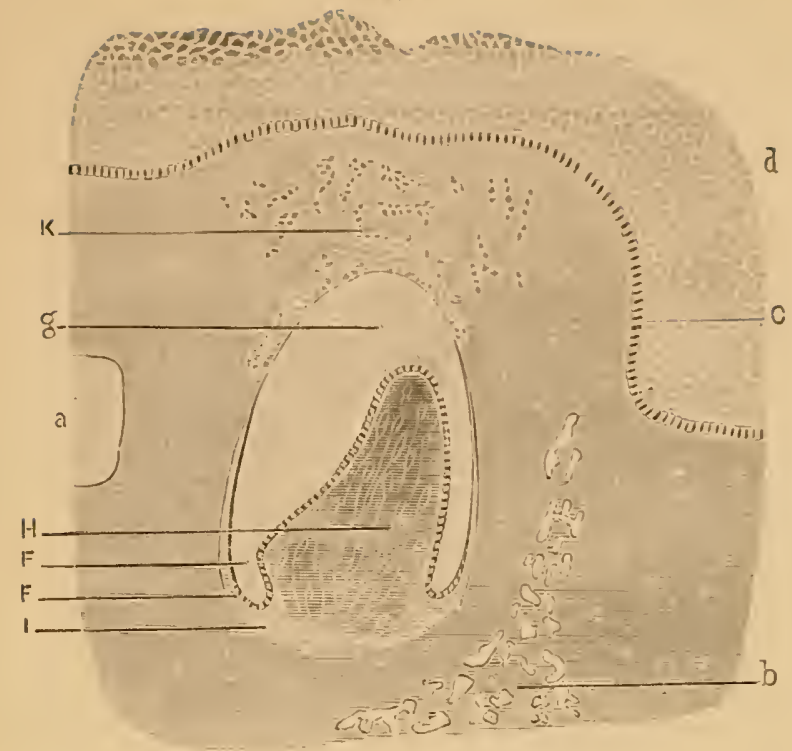

FIG. 39.

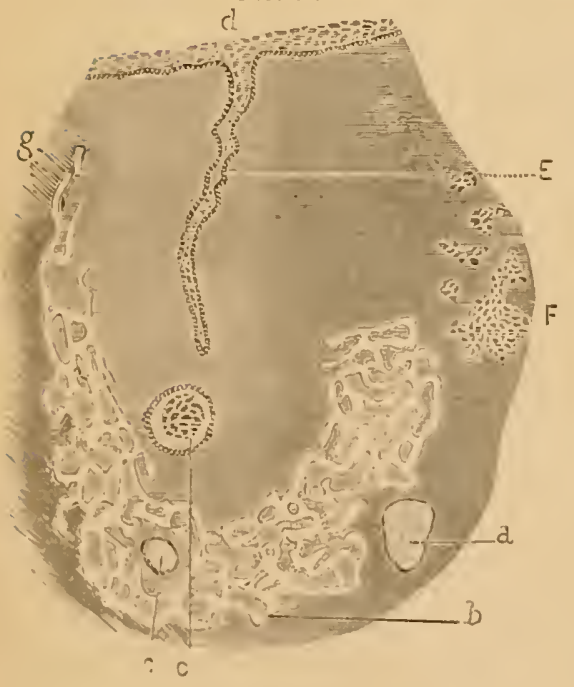

Fig. 40.

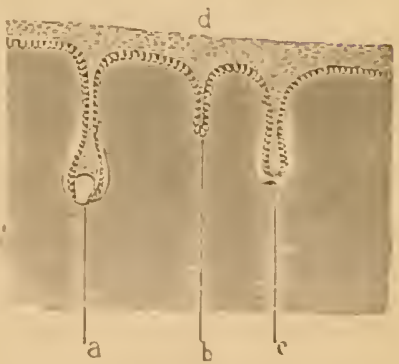


Frg. 41. - Section taken from the jaw of an embryonal calf, after the rupture of the epithelial cord. (Magnified 260 dian.)

This cut embraces the region external to the follicle $(\alpha)$, which latter is not represented in this figure. $b$, Epithelial buddings upon the follicular wall; $c$, epithelial lamina, still entire; $E, E$, buddings from the epithelial cord; $F$, globular epithelial mass in the lamina.

Frg. 42.- Section taken from a bovine embryo, and embracing the same territory represented in Fig. 41.

$a$, Segment of the follicular wall; $b$, epithelial buddings upon the wall; $c$, prismatic layer of the oral epithelium; $d$, oral epithelium; $E, E$, débris and budlings of the cord; $F$, epithelial globules from the débris of the epithelial lamina. (Magnified 100 diameters.)

For the physiological importance attributed to these epithelial proliferations, see pp. 66 and 179 . 
Fig. 41.
F11: 12

d.

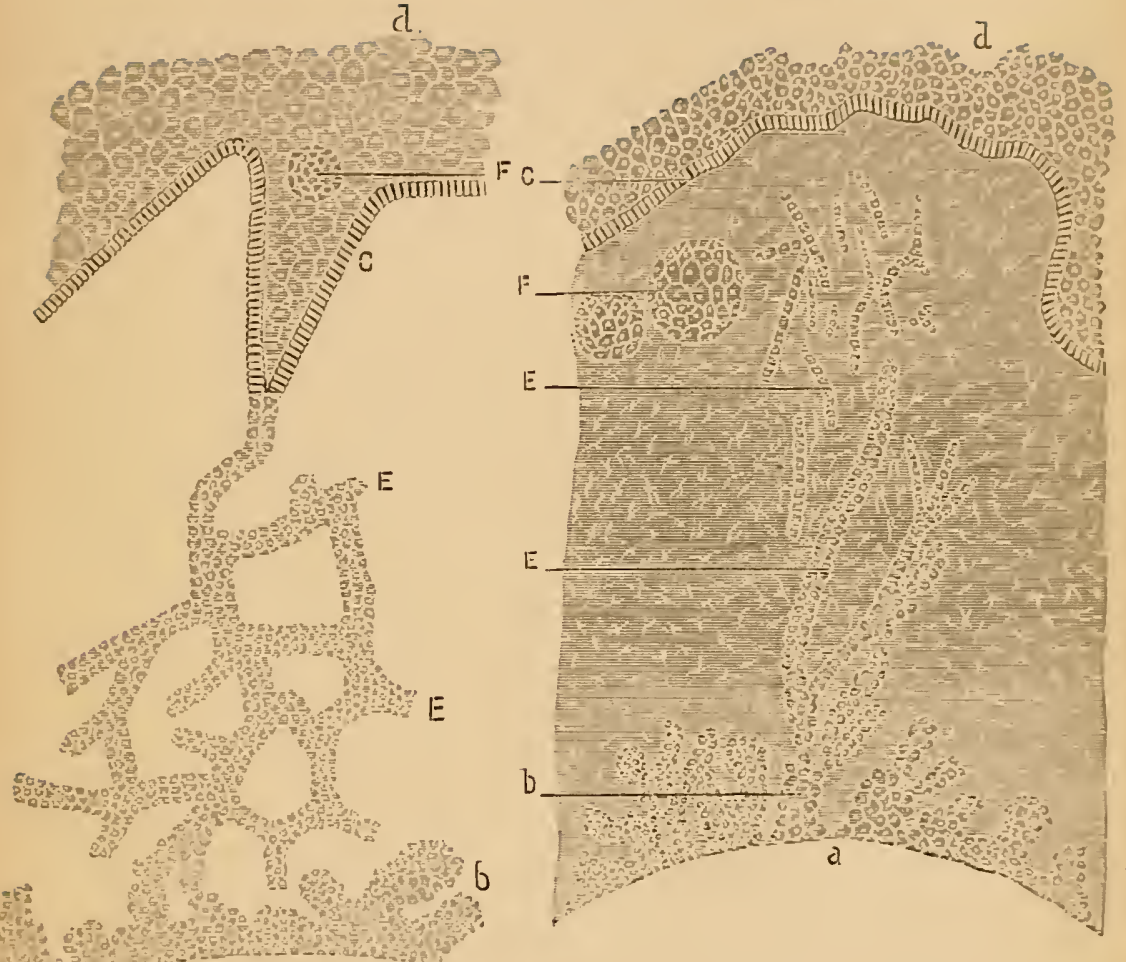


FIG. 43.-Vertical transverse section of the lower jaw of

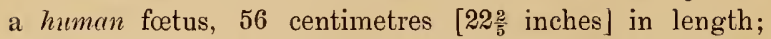
corresponding to about the period of birth. (Magnified 80 diam.)

$b$, Osseous formation; $d$, oral epithelium; $E$, lowest layer of the Malpighian stratum; $F$, débris of the epithelial lamina; $g$, enamel-organ; $H$, dental bulb; $I$, follicular wall; $j$, cap of dentine and enamel; $K$, débris of the secondary cord; $L$, bulb of the permanent tooth, capped with the enamel-organ .

FIG. 44.- Dental follicle of a permanent tooth of a cat; vertical and transverse section. From a preparation of Thiersch. (Magnified 14 diam.) Taken from the fifth edition of Kölliker's Elements of Human Histology.

$A$, Dental bulb, the external zone of which is formed by the odontoblasts; $b$, dentine; $c$, enamel; $d$, "internal epithelial layer of the adamantine organ or adamantine membrane" [the layer of prismatic or columnar cells that we denominate ameloblasts]; $e$, gelatinous tissue of the enamel-organ [stellate reticulum]; $f$, external epithelial layer of the adamantine organ [enamel-organ]; $g$, internal layer of the dental sac or follicular wall; $h$, external layer of the same.

[The white space seen between the layer of ameloblasts and the developing enamel is evidently accidental. See remarks on Fig. 24.] 

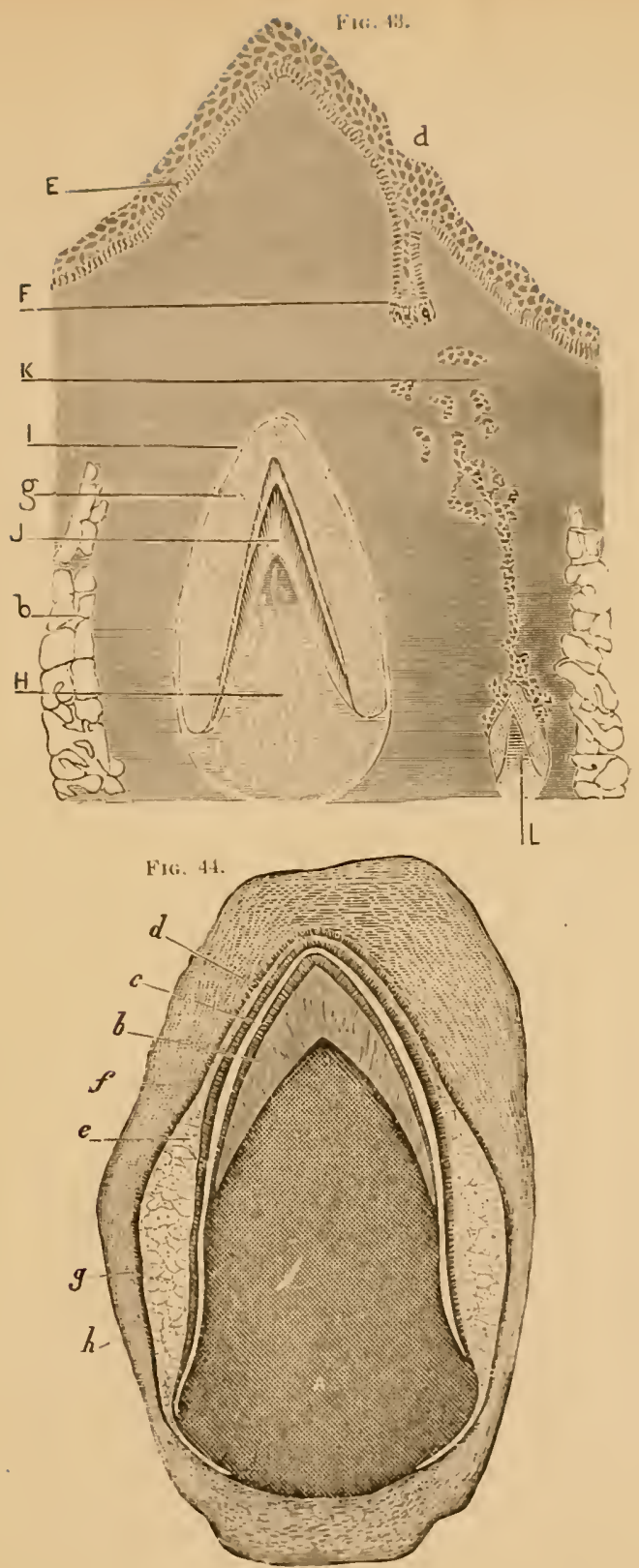


\section{N D E X.}

Adamantine membrane, 22, 109

Aggregations of epithelium, 125

Amelification, 91

Ameloblasts, 83, 91, 109, 151, 153

Amorphous layer, 17, 101

Apophyses, 28

Atrophy of Neckel's Cartilage, 37

Authors' introduction, 47

Bar of the solipeds, diastema, 55

Basement membrane, $14,17,21,24,88$ and 89

Bourgeons, 28, 44, 122, 130

primitive, 135 secondary, 134, 136

Bourrelet, epithelial band, 54

Cartilago dentalis, 54

Cell, apology for use of the term, 44

Cells, epidermal, 25

epithelial, in different stages of development, 20

aculeated, imbricated, prickle, spinous, ridged, 20

columnar, 21, 23

cylindrical, 21

polygonous, 22, 116. 132

prismatic, $21,81,83$

Cement, coronal, 111

Cemental organ, 111

Chronology of the dental follicle, periods of appearance of its parts, 147

Chronological table of dental follicle, 160

Corium, 12, 14

Cord of temporary teeth, 128

permanent teeth, 128

Corneous stratum, 15, 17, 19, 20, 23

Corneous leaf or plate, of Remak, 18

Cortical layer of enamel-organ, 82

Cuticle, 17

Cutis vera, 14

Definition of foetus, embryo, follicle and bourgeon, 41

Dental follicle, $89,105,111$

its genesis and formation, theories of criticised, 169 
Dental follicle, definition of, 42

origin and formation of, 49

Dental gern, $10 \tau$

groove. 135,150

sacs, 107

saceulus, 42,98

Dentine-bulb, 25, 42, 75, 90, 100, 112

origin and growth of, 983

lentine-cap, 152

Dentinal papilla, 25, 42. 75. 96

Dentinal sheet of tissue, 66 i

Dermal stratum, 21

tissues, 16

Dermis (derm or derma), 12,14, 16. 24, 26

Diagram of mucous membrane. 13

Diastema, or bar. 5.)

Diverticulum, 132

Double pellucid layer, between ameloblasts and tissues of pulp, 88

Farly development of the jaws, 27

Ecderon and enderon. 14

Embryos, canine, ovine, bovine and equine, study of, 161 to 168

Embryoplastic elements of incipient dental-bulb, 15,106

Enamel, formation of, dne to internal epithelium, $8 *, 83$

Enamel-cells, ameloblasts, 83

-membrane, 22

Enamel-organ, 21, 42, 83., 90. 93,96, 151

its clerelopment, 65

as fully developed, 75

as part of the dental follicle, 107

of the permanent tooth, 14:

Fnamel-or'crans of supernumerary teeth, 66

Epiblast, 18, 25

Epidermal cells, 25

membrane. 18

stratum, 21

Fpidermis, 11, 14. 19, 114, 119

Epithelial band, description of. $54.58,62,149$

Kïilliker's discovery of, 175,176

Epithelial cord, 66. 150

as determining the place and form of tooth. 97

when its course is finished, 12:3

of permanent follicles, point of origin, 137, 138

in embryo of two months, 150

Epithelial lamina, its origin and development, 62

at the period the enamel-organ loses connection with it, 105 
Epithelial lamina, phenomena located in it after rupture of cord, 115

sometimes the place of origin of cords of anterior permanent teeth, $13 \%$

place of origin of the cord of first permanent molar, 143, 144

proliferations, phenomena of, 121,122

Epithelial ridge or band, its origin, etc., 51

Epithelium, 11, 13, 18, 112

pavimentous or tessellated, 20

Errors of early observations, cause of, 17.5

External germinal layer, or epiblast, 18 osseous arch, 35

First permanent molar, its place of origin, 144

Follicle, definition of 43

epithelial proliferations upon, 121

Follicular wall, 42, 108 network of vessels upon, 112

buddings upon, 120,122

not closed at twelfth week, 152

Formation of enamel, due to internal epithelium, 82, 83

Formed material, Beale, 22, 23

Fusiform bodies, composing incipient dental bulb, 95

Genesis and growth of the dental follicle, theories of criticised, 169

of follicle, true order of, 174

of follicle,etc., summary of facts concerning, 180, 181

of follicle, conclusions regarding, 181 to 184

Glandulæ tartaricæ, 124

Hare-lip, its origin, 31

Horny layer of the epidermis, 23

Human embryo, relation between size and age, 148

Incisive or intermaxillary bourgeons, origin of, etc., 29, 31 period of union with the maxillary bourgeons, 50

Incisive region, 40

Initial spheroid, of Guillot. 173

Intermaxillary bones, 30 , 38

processes, 31

suture, 39

Intermediate membrane, of Henle, 12, 18

Internal cartilaginous arch, 35

epithelium of the enamel-organ of Kölliker, 22

Introduction, authors', 47

translator's, 9

Lamina, epithelial, 62, 70, 105, 115, 137, 144

Laminated membrane of follicular wall, 106

Last molar, its origin, 144 
Lateral buddings of primitive cord, 72

Nalleus, termination of Mecliel seartiligex, 3:3 ossification of its cartilacro, 34

Ilalpighhian stratum, 15, 1\%, 20). \$4

Mammillated form of incipient dental hulb, 9.5

Mamelibular processes, 32

Maxillary bourgeons, mion with intermaxillary, in lismpart, 52

Meckel's cartilacre, 27, 32, 50, 149

Iembrana adamantina, of Raschkow. 2:2

Fboris, 91

mucosa, 13

preformativa of Raschkow, 18, 88, 90, 101, 101;

preformativa of Huxley, 85,90

proprial, 12

Mesolulast, the origin of the dermis, 19

Mincosit, 14

perioul at which developed, 25

Mucous layer, 12

Ilucous membrane, ?

Odontoblasts, tissue in which they first appear, 101

Odontogenic pars. or the generating part of the teeth, 51

Odontomes, 159

Oral epidermis, divisible into two laminre, 19

Origin and formation of the dental follicle, 49

Origin and formation of the dental bulb and follicular wall, 93

Pars papillaris, or 1 - $13,15.25$

Papillary layer, ;

Pars reticularis, reticulary liyer. 13. 15. 25

Pellucill layer, ss

Periplast of Huxley, 22

Permanent follicles that have been preceded by temporary ones, 129

commencement of, 153

Phenomena that follow formation of follicle, etc., 115

Platean of the prismatic cells. 87

Premaxillie, 40

P'rimitive bourgeon of the follicle, 65

Primitive papilla. 95

Primitive follicle after ruptnre of cord, 123 modifications in surromding parts, 135

in relation to origin of secondary cord, $13 \mathrm{~s}$

l'rimitive cord, prolongations of, 128 point from which secondary hourgeon starts, 140

Prismatic layer of cells, $23,59,82,109$

Processes, apophyses or bourgeons, 2S 
"Proper " mucous membrane, 13, 14

Pulp of enamel-organ, stellate arrangement of, 80

Raschkow's theory of origin of follicle, 171

Reticulary layer, 13, 15, 25

Ruptured cord, 135

Scarf-skin, 17

Second molar, origin of, 144

Secondary bourgeon, its descent into dental groove, 134 in lower animals, 136 and point of origin, direction it takes, 140

Secondary cord, 139 development of, 153 separation of, 154,155

Secondary follicle, 123, 141

Semilunar area, origin of dentine germs, 98

Skin, analogous to mucous membrane, 16

Stellate bodies, transformation of cells of the enamel-organ, 69,78

Stratum corneum, 23

Malpighii, 12, 20

Malpighii prismatic layer derived from, 59

Subcutanea, 15 intermedium, 84, 153

Subdermal areolar tissue, 25

Suludermis, 15

Submucous tissue, 25

Submucosa, 13, 15

Superior maxillary processes, 31

Tartaric glands, 124

Tela mucosa, 13,15

Temporary follicles, generally the source of the twenty anterior permanent teeth, 137

The epithelial lamina and genesis of enamel-organ, 62

The mode of origin of follicles of permanent teeth, 127

'Third molar, place of origin, 138, 145

Tongue, apophyses, etc., 28

Translator's introduction, 9

True epidermis, 17

Tubercles, bourgeons, processes, etc., 28

Upper jaw, its development, 50

Vessels of the bulb, 126

Visceral arch, 2s

Wisdom tooth, its origin, 138, 144 


RK280

Legros
LS

Cony 1

Origin and formation of the dental

follicle. $(0-20-32$ 
